\title{
The Historical Industrial Development, Regional Economic Analysis, and Household Livelihood strategies of a Rural Pennsylvania Community: A Case Study
}

Amanda. L. Krugh

West Virginia University

Follow this and additional works at: https://researchrepository.wvu.edu/etd

\section{Recommended Citation}

Krugh, Amanda. L., "The Historical Industrial Development, Regional Economic Analysis, and Household Livelihood strategies of a Rural Pennsylvania Community: A Case Study" (2011). Graduate Theses, Dissertations, and Problem Reports. 3478.

https://researchrepository.wvu.edu/etd/3478

This Dissertation is protected by copyright and/or related rights. It has been brought to you by the The Research Repository @ WVU with permission from the rights-holder(s). You are free to use this Dissertation in any way that is permitted by the copyright and related rights legislation that applies to your use. For other uses you must obtain permission from the rights-holder(s) directly, unless additional rights are indicated by a Creative Commons license in the record and/ or on the work itself. This Dissertation has been accepted for inclusion in WVU Graduate Theses, Dissertations, and Problem Reports collection by an authorized administrator of The Research Repository @ WVU.

For more information, please contact researchrepository@mail.wvu.edu. 
The Historical Industrial Development, Regional Economic Analysis, and Household Livelihood strategies of a Rural Pennsylvania Community: A Case Study.

Amanda. L. Krugh

Dissertation submitted to the Eberly College of Arts and Sciences at West Virginia University in partial fulfillment of the requirements for the degree of

Doctor of Philosophy in Geography

Ann Oberhauser, Ph.D., Chair

Greg Elmes, Ph.D.

Melissa Latimer, Ph.D.

Cheryl Brown, Ph.D.

Jeremia Njeru, Ph.D.

Department of Geography

Morgantown, West Virginia 2011

Keywords: Regulation Approach; Rural Geography; Livelihood Strategies; Social Embeddeness

Copyright 2011 Amanda Krugh 


\begin{abstract}
The Historical Industrial Development, Regional Economic Analysis, and Household Livelihood strategies of a Rural Pennsylvania Community: A Case Study.
\end{abstract}

Amanda L. Krugh

This dissertation research focuses on the case study area of Mount Union, Huntingdon County, Pennsylvania. This three part dissertation research project includes analysis of the historical industrial development, current economy, and household livelihood strategies of this rural community. The regulation approach is utilized in this paper to analyze the historic economic development associated with manufacturing, specifically brick manufacturing, in the case study area. Quantitative techniques are used to indentify the economic structure of a region and used to examine the strengths and weaknesses of the Huntingdon County economy. Qualitative methods are utlized to examine what economic and social adjustments and livelihood strategies are made in response to economic change. 


\section{Table of Contents}

Chapter 1. Article 1

Article 1 Work Cited 32

Chapter 2. Article 2

Article 2 Work Cited 79

Chapter 3. Article $3 \quad 81$

Article 3 Work Cited 105

$\begin{array}{ll}\text { Appendix A } & 108\end{array}$

$\begin{array}{ll}\text { Appendix B } & 120\end{array}$ 
Chapter 1.

This chapter was completed in the MLA style for publication in Appalachian Journal.

\section{The Historical Development of a Rural Industrial Community: A Regulation Approach.}

\section{Introduction}

The industrial revolution was an important force for social and economic change in not only urban regions, but many rural areas in $19^{\text {th }}$ Century Untied States. An overall decline in demand for labor the agricultural sector left many rural communities in the United States struggling to survive as the agricultural workforce out-migrated to urban centers for industrial jobs (Falk et al. 2003). These jobs provided relatively stable work and better wages than farming (Luloff and Chittenden 1984) (Dennis Roth 2000). As industrial production matured, the locations of industrial manufacturing facilities were no longer restricted by transportation, labor, and infrastructure in metropolitan areas. By the late $19^{\text {th }}$ and early $20^{\text {th }}$ century, increased transportation, workforce and land area needs of manufactures (Falk et al. 2003). In particular, branch plants, controlled and operated by urban-based manufacturing companies, benefited from access to raw materials, large amounts of land, and a labor force in need of work (Roth 2000). Within a few decades many rural communities which once focused on agriculture had transformed into towns with economies centered on manufacturing and industrial production. This paper examines the development and subsequent decline of a rural industrial economy, using the regulation approach to explore the connection between social, cultural, and economic change in the Mount Union, Pennsylvania. 
Industrial development flourished in the rural northeast United States in the late $19^{\text {th }}$ century. Pennsylvania's s iron, steel, coal, and coke industries, supported by extensive transportation networks and abundant raw materials, combined to create an industrial region unrivaled at the turn of the century (Department of the Interior 1994). During this period, the steel industry in Pennsylvania experienced technological advancement as well as an increased demand for steel by the expanding national railroad system which brought it to the forefront of the United States industrial revolution (PennState Department of Landscape Architecture 1995). Steel and iron production in particular transformed the landscape and economy of this region, and many rural Pennsylvania communities based their entire economies around these industries (White 1928) (High 2003).

Throughout the mid to late $20^{\text {th }}$ century, slow growth, global competition, divestment and decline of investments within U.S. steel companies, and increasing deindustrialization throughout the United States impacted the economy of the region. The associated job loss, factory closings, and the displacement of workers affected rural communities throughout the region (Wallace 1993) (High 2003). This economic downturn can be partially attributed to how capital in the form of national investment in new factories, equipment, and workforce training was diverted from a focus on United States' production to one of investment in mergers, acquisition, and foreign markets through globalization (Bluestone and Harrison 1982). Although this decline occurred nationally across all sectors, the manufacturing sectors, and rural areas dependent on manufacturing, in particular, have been impacted by this economic shift. 
. Work and community involve a variety of embedded social relations that link households, economy, industries, and cultural values (Falk et al. 2003). There is a diminished capacity for rural households to interact in singular economic or social roles due to factors including low population, limited social outlets, and limited economic opportunities (Marini and Mooney 2003). Based on these factors, complex interactions between social, cultural, and economic roles occur in many rural areas. Work in these rural settings is not limited to production and instead, intersects with local contexts of social and cultural structures that have historically specific and distinct regional contexts.

Within rural research, the regulation approach and regulation concepts are used by some scholars to explore the rural economy and examine wider aspects of rural change (Goodwin 2006). As a contribution to rural research, the regulation approach enables a holistic model of analysis that doesn't focus on outside forces as the primary cause for change. Instead, this approach is designed to examine the complex relationships of capital accumulation, economic crisis, and economic, social and political change at multiple levels (Knudsen et al 1997). This approach shows how these changes occur in different rural areas based on particular and distinct economic, social, and cultural conditions (Goodwin 2006). Regulation is used in this research to explain why and how capitalist accumulation and economic crisis, which are fundamental and enduring features of capitalism, vary by time, space, and place and distinctness of how regulation historically occurred in the case study community.

The first section of this paper outlines the use of the regulation approach to study rural economic restructuring and social change. The regulation approach will be utilized to examine the connections between economic, social, and cultural change and how these 
changes are regionally distinct and unique. The main concepts of regulation theory will be defined and explained as to how they specifically relate to rural research.

The second section of this paper provides an overview of my research methodology. The specific regulation concept used for this paper, the mode of regulation is explained. A discussion of how the mode of regulation concept is used within rural economic and social research is discussed. Archival research is the primary source of information for the case study of this paper. The location, description, and type of archival resources used for research will be described. This section will also introduce my case study area and reasoning for choosing this particular region for this study.

The third section of this paper introduces the case study area, the community of Mount Union, Pennsylvania and the surrounding region. Mount Union has a rich industrial history tied to manufacturing, specifically brick refractories, which were the economic backbone of this region for decades starting in the late $19^{\text {th }}$ century. Mount Union's industrial economic history is uniquely connected to social and cultural regulations through company controlled housing and paternalistic oversight of brickyard workers.

Analysis of Mount Union's brickyard industrial era occurs in the fourth section of this paper. The regulation approach is used to examine periods of accumulation and times of crisis in Mount Union, a town with a unique economy, culture, and social context. The impact and social and economic control of the brickyard companies varied throughout the era of industrialization. This study examines how the complexity of local cultural, economic, and social interactions in the context of the community and the brick 
companies facilitated the economic and social change that occurred during periods of economic expansion and in times of economic crisis (Wallace 1993).

The conclusion of this paper summarizes how the regulation approach was used within this research to evaluate the industrial development and decline of Mount Union. The regulation approach is used to examine ways in which capital accumulation is a socially embedded and regulated process. Researchers use the regulation approach to examine the multiple and unique social, cultural, and institutional contexts where economic production is sustained, expanded, or within periods of crisis and economic decline. The conclusion of this paper highlights how economic, social, and cultural changes that occurred in the historical industrial period in Mount Union, Pennsylvania were intrinsically linked.

\section{Theoretical Framework - A Regulation Approach}

Regulation theory influenced Marxist political economy throughout the 1980s and early 1990s (Jessop 1997). This approach originated in the 1970s with a group of French economists who opposed neo-classical economic thought where it was understood that the economy is regulated by the market, and the "laws" of supply and demand are responsible for continued reproduction of capitalism (Goodwin 2006) (Uffer 2008). Regulation theory critiques this assessment of continued capital accumulation, and instead approaches the regularization or normalization of the economy through social,

political and cultural support. The assumption is that crisis is an intrinsic character of the capitalist system, and can be stabilized and regulated through social, political, and cultural institutions that make reproduction of the capitalist mode of production possible (Broomhill 2002). 
Two concepts, accumulation regime and mode of regulation, are key to understanding the stabilization and regulation processes of capitalist production within regulation theory. Regime of accumulation refers to the balanced pattern between production and consumption which is reproducible over extended periods of time (Jessop 1997a) (Munton 1995). Regimes of accumulation are stabilized by modes of regulation which are a complex combination of social, political and economic institutions. The ensemble of rules, norms, conventions, networks, and organizations associated with these institutions regulate the accumulation regime allowing for economic growth (Uffer 2008) (Goodwin 2006).

Regime of accumulation and mode of regulation originated with regulation theory, but today are used within a wide range of research agendas, disciplines, and studies (Mavroudeas 1999). This variety of research agendas is a point of contention among critics of regulation theory that stresses the fact that a distinct and theoretical path has failed to emerge. Presently, however, many researchers utilize concepts of regulation theory to inform their work without aiming to use regulation as an overall explanatory theory. Currently, regulation approach is used instead of regulation theory by researchers in recognition that regulation theory has evolved more as a research program, a method or approach, rather than a unified theory (Broomhill 2002). As Goodwin and Painter explain (1996, 640):

"It is not a complete theory of social and economic restructuring, nor, in essence, does it contain a substantive account of the path of development of particular economic spaces. Rather, as we have suggested it is a method or analytical approach which allows an assessment to be made of the effectiveness of regulation in different places and at different times. Where a mode of regulation can be identified, it provides an explanation of its operation, success and eventual decline.” 
At its conception, regulation theory was intended as a tool for understanding changes in economic institutions and capitalist accumulation as they occur at global and national levels (Cloke and Goodwin 1992). In contrast, the contemporary regulation approach shows a more localized understanding of periods of economic and social change (Drummond 2000) (Broomhill 2002).

This paper utilizes the regulation approach for rural research to explore the rural economy and examine wider aspects of rural change (Cloke and Goodwin 1992). Regulation is not an inevitable, automatic, or structurally necessary process, but instead involves intentional social practices and is usually the result of individual and varied elements such as social structure, industrial history, or economic variables. Regulation occurs in different ways and with different outcomes. Various forms of regulation occur differently in rural areas based on particular and distinct economic, social, and cultural conditions (Jessop 1997) (Peck and Tickell 1995). In this discussion, the regulation approach examines divergent rural spaces are unique in both continued capitalist accumulation and periods of crisis and restructuring (Goodwin et al. 1995) (Goodwin, 2006). This approach is "an on-going research programme, with a set of conceptual devices and an evolving methodology” (Peck and Tickell 1995, 16). Given the diverse use of the regulation approach within rural studies it is important for the researcher to identify precisely which regulation concepts are being used and to outline how they will be used in a clear and specific way (Goodwin 2006).

\section{Methodology}

This paper uses the mode of regulation to analyze the historic economic development of the brick refractories industry in the case study area of Mount Union, 
Pennsylvania (Goodwin 2006). Critics claim that researchers using regulation concepts are looking for an overarching and undifferentiated transformation from one regime to the next. Classic Parisian Regulation research confines industries, regions, and economic development into to two primary development stages, Fordism and post-Fordism, contemporary rural research using the regulation approach is not limited to these notions (Page and Walker 1991) (Mavroudeas 1999) (Page 1997). Cloke and Goodwin clearly warned against "any attempt to fit the complexities of rural restructuring into grand conceptual containers such as Fordism and post-Fordism” (Cloke and Goodwin 1992, 327). Current rural regulation research stress variability and difference. Contemporary works use the regulation approach to provide accounts of historical regional development that stress diversity and complexity. A variety of social norms, economic conditions, historical context, political practices, and institutional structures occur within any mode of regulation. Based on unique context and conditions of the locale, development occurs differently (Broomhill 2002).

Regulation is not inevitable or necessary for capital accumulation, and in fact the occurrence of effective regulation is rare, and involves intentional and purposeful social action. The mode of regulation, when it occurs, refers to the multiple political, societal, and economic organizational arrangements that when combined provide the support needed to sustain economic growth (Broomhill 2002) (Uffer 2008) (Bluestone and Harrison 1982) (Goodwin and Painter 1996). Regulation is a creation of social systems, which vary through place, space, and time and involve multiple social, cultural, and institutional contexts. Within research when a mode of regulation is identified, analysis is concerned with the diversity of how and why these varied social systems allow for 
capital accumulation to occur. As a socially based process, regulation is dynamic and vulnerable to crises. Any mode of regulation will be effective for only a period of time. In addition to capital accumulation, the regulation approach and mode of regulation analysis can be used to examine how and why the particular mode of regulation failed in the context of a specific region’s economic and social constructs (Goodwin and Painter 1996) (Goodwin 2006).

For decades, brickmaking was the prime employer of the case study community of Mount Union and much of the industrial development and economic expansion of this area is attributed to this industry (U.S. Department of the Interior 1994). The specific modes of regulation formed in the historic development of this industrial area are distinctive to the social, political, and economic context of this region. The regulation approach is used to examine the unique and distinctive ways that capital accumulation as well as periods of economic decline and crisis occurred as a socially embedded and regulated process in Mount Union, Pennsylvania during the industrial refractories period.

Archival geographical research is used to analyze are the historic economic development of the Mount Union region (Hay 2005). Archival geographical research provides a means to answer questions about a region's past and place in history. Repositories of historic documents provide an in situ perspective on historic events valuable to research (Nakazawa et al. 2009) (Roche 2005).

Several resources used for this project include the Huntingdon County Historical Society, Pennsylvania State Archives, Mount Union Historical Society and the National Park Service. The Historical Societies of Mount Union and Huntingdon County provide a great deal of regional and local documents, books, and newspapers that focus on the local 
region. Archival resources from the National Park Service involve a project initiative to inventory historic sites in southwestern Pennsylvania. The Historic American Buildings Survey (HABS) and the Historic American Engineering Record (HAER), form a division of the Park Service, began a multi-year historical and architectural documentation project in order to identify surviving historic engineering works and industrial resources in the

Southwest Pennsylvania Region. This project of the National Park Service, in coordination with America's Industrial Heritage Project (AIHP), began an initiative in 1987 to inventory historic sites in southwestern Pennsylvania. Research specific to the Mount Union region including newspaper articles, historic surveys, recorded interviews, and historical mapping were gathered as part of this program and are now housed in archives at Indiana University of PA. For this research an extensive amount of data from the historical building surveys and recorded interviews were utilized supported with information from historical newspaper articles and mapping.

\section{Case Study Area - Brickyards of Mount Union, PA}

The mode of regulation provides a unique perspective on the historical industrial development of the Mount Union community. This discussion focuses on the historical refractories industry. While there are other notable periods of development and growth in this region, they are attributed more to trade, commerce, and increased transportation than the production and industrial economic development that the brickyard refractories brought to the region (National Park Service 1990b) This research explores the complex make up of economic development, social structure, and historical context of the industrial era of Mount Union, Pennsylvania. 
The community of Mount Union emerged from several settlements that formed in the central Juniata Valley, Pennsylvania in the late 1700’s. Mount Union's continuous position as a regional transportation hub helped shape its growth and played an important part in opening the area to industrial development (see Figure 1 and 2).

Figure1. Mount Union, Huntingdon County, Pennsylvania

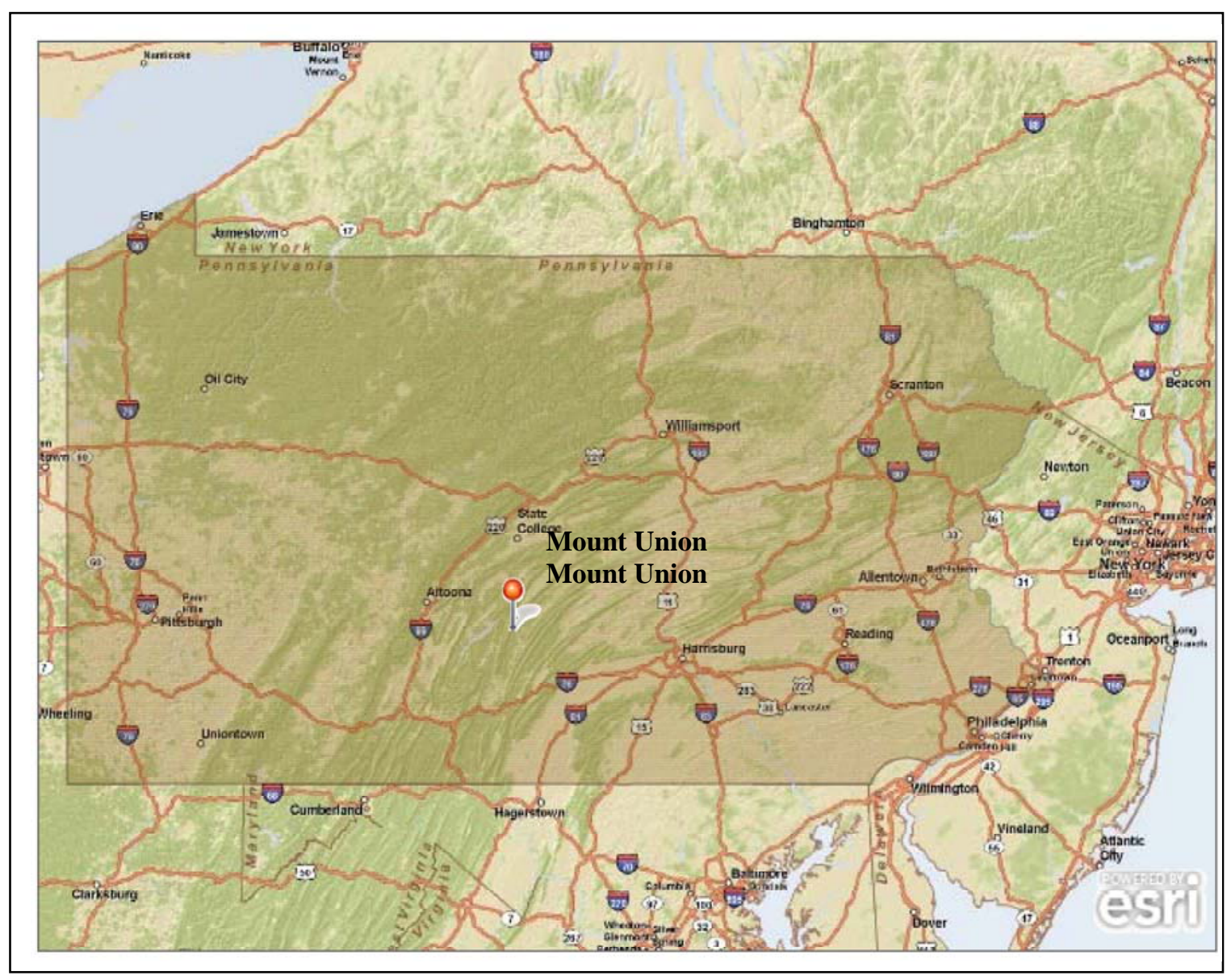

.Source: ESRI online mapping

The Lower Juniata Division of the Pennsylvania Mainline Canal was built through Mount Union between the years of 1828 and 1830, marking a major turning point in the community's history. Before construction of the canal, Mount Union had changed very little throughout the early $19^{\text {th }}$ century. The area was sparsely populated 
and consisted of a few independent settlements that lacked the continuity of a traditional community (Southwestern Pennsylvania Heritage Preservation Commission 1993). The canal intersected with several major road systems in the area now known as Mount Union and became an important transfer point for travelers and freight injecting a new life and energy into the area. As the population began to grow, accommodations such as a tavern, hotel, and warehouse were built to accommodate the many travelers coming to the area (PennDOT District 9 1988) (U.S. Department of the Interior 1994). Commerce from the canal was also a means for early village growth.

Figure 2. Historic Map

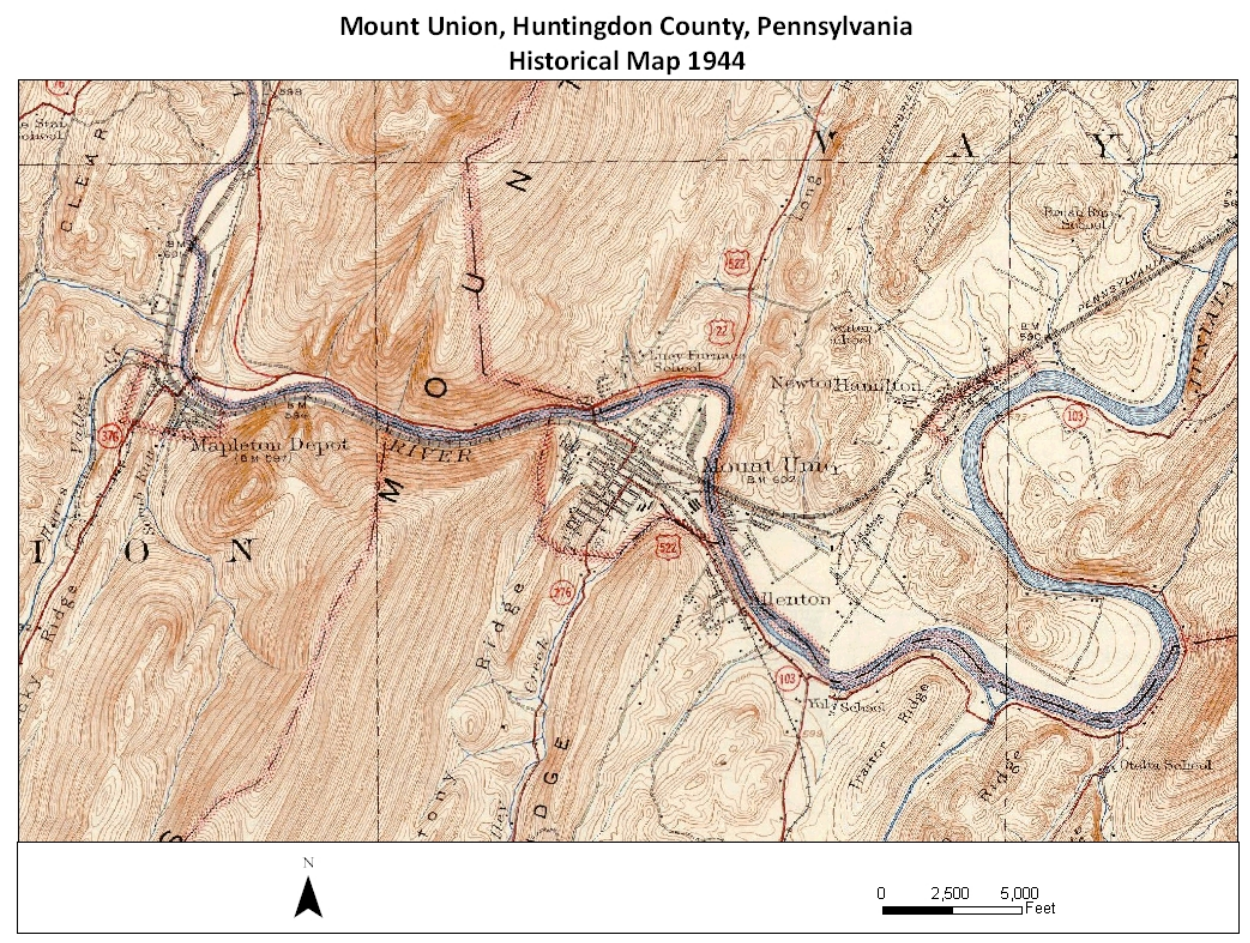

The Pennsylvania Railroad arrived in the town of Huntingdon in the mid $19^{\text {th }}$ century, and it was anticipated that the railroad would soon extend to Mount Union, located only 20 miles away. The new town plan centered around the railroad right of way and away from Water Street and the canal, signifying a new focus on the railroad for 
the community (Huntingdon County 1978). Completion of the Pennsylvania Railroad through Mount Union in 1850 was a significant event in the community's history and marked the beginning of the canal's decline. The efficiency and reliability of the railroad, which became the principal east west rail corridor in Pennsylvania, outperformed the seasonal and maintenance intensive canal system (Huntingdon County 1978). Completion of the Pennsylvania Railroad's Mountain Division in 1854 provided the last link in the rail system running between Pittsburgh and Philadelphia and resulted in incredible prosperity for towns located along the route. The Pennsylvania railroad was a catalyst for industrial development in Mount Union and in fifteen years it village was an industrial and commercial center which served a large rural population (Wallace 1993) (SPHPC 1993). The town had evolved from a small village into an urban planned town with distinct areas for industry, commerce, and residence.

In the late $19^{\text {th }}$ century the discovery of high quality ganister sandstone on the nearby slopes of Jack's Mountain brought the silica refractory brick industry to Mount Union, and the town changed drastically (PennDOT District 9 1988). Because of its high alumina clay and silica content, refractory brick, also known as silica brick, is resistant to thermal stress and chemical abrasion common to most manufacturing and technological processes (Wallace 1993). In the early $20^{\text {th }}$ century refractories, silica brick production plants, were an essential part of industrial manufacturing. Steel and iron production led to intense development of the refractory industry in Pennsylvania (National Park Service 1990c).

W.H. Haws, a local businessman, built the first large brick works in Mount Union in 1899. Within a year he sold the operation to Harbison and Walker of Pittsburgh. 
Harbison Walker was one of the largest refractory manufactures in the world. This plant was the first in the United States to be used exclusively for the manufacturing of refractory brick. Within ten years two more brick refractory plants came to Mount Union, the Mount Union Silica Brick Company, and Mount Union Refractories (National Park Service 1990a).

The brick industry quickly transformed Mount Union. During the early $20^{\text {th }}$ century, its growth included operation of the three brick plants, a government sponsored munitions plant, a shirt factory, and a gunpowder plant. By 1912 all three refractories required over 3000 employees, more than the population of the entire town (Wallace 1993) (PennDOT District 9 1988). The brick companies, along with a government munitions factory imported workers to satisfy their need for labor tripling the borough’s population tripled between the years of 1900-1910 from 1086 to 3338 (National Park Service 1990b).

In their earliest form, brickyards were used as investment options by local businessmen and often were family run operations that employed local workers. As the steelmaking industry exploded in the late $19^{\text {th }}$ century, the need and demand for refractory bricks to support steel production greatly increased. As the vast supply of ganister in Central Pennsylvania was realized, national companies began to establish themselves in the region (National Park Service 1990b). The local small business model was abandoned as family-run businesses were bought and incorporated into large, national organizations controlled by non-residents. Mount Union benefited from prosperity and growth, but also found itself economically and politically dependent on outside control of the brick companies. At the peak of the brick refractory industry in the 
early $20^{\text {th }}$ century, three main refractory brick companies with branch plants throughout the central Pennsylvania region came to Mount Union. These were Harbison-Walker Refractories Company from Pittsburgh; North American, headquartered in Cleveland; and General Refractories out of Philadelphia (National Park Service 1990a).

This transformation from small production plants to modernized operations also required up to date plant machinery and a large labor force to insure high production and efficiency (Wallace 1993). The thousands of workers brought in by the brickyards that changed the cultural and social make up of the community, which further stressed the control that the brick industry had on Mount Union. Many of the workers who came to Mount Union during this period were African Americans or Eastern European immigrants. The companies recruited this population because they were usually nonunion and worked for a lower pay rate. Previously Mount Union’s population was relatively homogenous, mostly Caucasian "old stock" Protestant population, however, the influx of thousands of new workers changed Mount Union’s ethnic and racial makeup drastically (Wallace 1993) (PennState Department of Landscape Architecture 1995). Demand for housing in Mount Union prompted the brick refractories to create their own small settlements where they could oversee their workers (National Park Service 1990b). This was a clear and calculated strategy used to manage and control labor to allow for continued production of refractory bricks.

In sum, Mount Union became a major site for silica brick production and industrial center, far from its rural and mainly agricultural history and context of the $19^{\text {th }}$ century. (PennDOT District 9 1988). The demographics, landscape, and economy of the community were significantly altered. The brickyard companies led the town through this 
"restructuring" using company housing and social programs to stabilize the work force in order to maintain productivity (Wallace 1993). During the industrial refractories period Mount Union truly became a "brickyard town” (PennState Department of Landscape Architecture 1995) (U.S. Department of the Interior 1994).

\section{Mode of Regulation and the Brickyards}

This paper uses the mode of regulation concept to assess the historical Mount Union refractories industry including the periods of development, peak production, and decline. The process of capitalist accumulation is socially embedded and socially regulated. This analysis of Mount Union's refractory industry provides an historical, local, and distinct account of this process.

Multiple cultural, social, and institutional aids combine to sustain and promote economic expansion and growth. Analysis of these supports through the mode of regulation approach considers specific local and historical context as key to understanding economic and social processes (Broomhill 2002). It is understood that this concept does not imply a "mode" as a completed system, nor does it provide an absolute theory of social and economic restructuring (Goodwin 2006). Painter and Goodwin stress the importance of understanding regulation as a process that has "ebb and flow" continually changing through space and time.

"the term "mode" is often understood as implying a completed system, rather than one in the process of formation...the notion of modes of regulation overemphasizes the functionality, stability, and coherence of regulatory relations and underemphasizes change, conflict and development during their period of operation”(Goodwin and Painter 1996340 -341 ).

The mode of regulation is a process that is often complex, conflicted, and diverse.

Researchers look at how this complexity and diversity is manifested by local social and historical contexts during periods of economic and social change (Uffer 2008). This 
paper utilizes the mode of regulation concept to analyze the particular complexity, conflict, economic expansion, stability, as well as the subsequent economic decline that occurred during the refractories industrial period in Mount Union, Pennsylvania. This discussion focuses on company housing, social programs, and the impact of industry decline on the community, as examples of how modes of regulation are manifested within the community of Mount Union during times of economic and social expansion, stability, and periods of economic crisis and economic decline.

\section{Development of the Historic Brickyard Industry in Mount Union: Economic Expansion and Stability}

\section{Company Housing and Social Programs}

Throughout the early $20^{\text {th }}$ century the brick refractory industry remained very labor intensive, requiring a great deal of manual labor and site-specific knowledge and skill that comes with years of experience. A large proportion of cost associated with brick production went to labor as the demand for refractory bricks outpaced the development of automated machines. Even companies that used mechanized brick presses in the early $20^{\text {th }}$ century still required a large amount of hand labor due to the increase in the amount

of bricks that had to be dried and burned, a process which was not automated until decades later than the presses. Because of their reliance on labor, refractories companies focused on making their workers as efficient and productive as possible (Wallace 1993).

The rate of growth and development that the three brickyards brought to Mount Union was unprecedented in the region. Despite the demand, company housing was not simply a response to a shortage of worker accommodations but was instilled as a management strategy. Each of the three brickyards incorporated housing as a physical 
part of their factory complex and used the company housing to create greater productivity from their workforce (Wallace 1993). Along with the actual buildings, company housing provided the brickyard owners the needed stability and control to run their plants. Company housing was used as a tool to improve the labor force and often considered a part of the industrial infrastructure used to insure uninterrupted production (National Park Service 1990b).

Company housing is often associated with coal mining companies that brought labor to remote mining areas. For example, southern Pennsylvania, historically a center of bituminous coal mining, required housing and infrastructure to support the development of hundreds of mines in the late 1800s (Mulrooney 1991) (Wilson 2004). Company housing as a response to labor needs and management of the workforce were similar in both mining towns and the brickyards community of Mount Union. There are differences between the company towns. For instance, coal company housing and infrastructure in Pennsylvania were often built in remote and undeveloped areas. It was advantageous for coal mining companies to operate in isolation without competition because the extraction process was tied to a particular location. The coal companies often owned the coal mines as well as large amounts of land surrounding the area which effectively blocked other industries from entering the region (Bell and York 2010).

In contrast, Mount Union was an established community before the brickyard industry came to the region. Brickyard housing in Mount Union was partially used to influence a largely immigrant and culturally varied workforce to better fit with the established local social structure. Also, while the brickyard industry was ultimately tied to the large local supply of ganister sandstone, the focus of the brickyards was not on the 
extraction of material, as with coal companies, but on brick production. For the Mount Union area, where ganister sandstone was readily available, competitive strategies amongst the brickyards were not focused on land ownership and extraction but instead centered on improvements and technology related to production. Each brickyard had a different approach to production and labor management was included as part of the strategy. Unlike the uniformity of much coal housing which was often constructed by a singular company, the brickyard housing in Mount Union varied by the needs of the three companies and included a multitude of designs and layouts (Mulrooney1991) (National Park Service 1990b). Housing was a viable option for all companies but the policies were not uniform across the industry, and instead molded by the history, conditions, and needs at each brickyard. (National Park Service 1990b).

The brickyards employed over two thirds of the Mount Union population during the refractories industrial period included native born, white Americans, immigrants, and African Americans (SPHPC 1993). The influx of a workforce that was primarily immigrant and non-local posed the potential for social conflict within the community. This conflict had the potential to decrease production and the ability for industrial growth of the brickyards. Housing as a mode of regulation was implemented as a strategy to ensure the workforce was compliant to the needs of the brickyards. The physical structure and layout of the company housing were used as tool to control and regulate production and capital accumulation. The main function of company housing in Mount Union was to “Americanize” the largely immigrant and non-local population (Wallace 1993) (National Park Service 1990b). Mode of regulation is a complex and diverse process whose effectiveness and purpose is determined by various factors and context (Goodwin 
and Painter 1996). This understanding of regulation is illustrated by the diversity in housing provided by each of the brickyards. Although each of the three companies designed accommodations for families and longer term residence, the specific profile of company housing was different for each refractory (SPHPC 1993). Harbison-Walker, the largest refractory in Mount Union built 100 houses in 1916, forming a neighborhood called Ganister Hill. The houses were two story frame buildings with a third of the houses constructed as duplexes. The buildings were clearly the creation of a company engineer, with a rigid box like symmetry set in ordered rows in sight of the brickyard (see Figure 3). The balanced order of the houses ordered around the hillside exemplifies the company’s paternalistic approach to labor management. The Harbison-Walker company also considered the integral role in the program of social and cultural transformation housing provided their workers. Housing became part of their "social uplift" program. Housing was in close proximity to the brickyard and the layout suggests the strong supervisory role the company took over its workers (National Park Service 1990c).

Across town, General Refractories, a smaller plant with fewer employees, built housing that was less coherent with little uniformity or consolidation. The housing provided by this refractory company included buildings located in town often blocks from the brickyard, a shanty town of small one story houses, and some two story houses built adjacent to the brickyard (Wallace 1993) (National Park Service 1990a). This brickyard refractory operated on a smaller scale than the other two brickyards and the workers on average were younger and more transient than those hired by the other two refractories, and didn’t require family friendly housing. 
The third refractories company, Mt. Union Refractories (later becoming North American Refractories), had the most extensively planned environment provided for its workers. The company commissioned John Nolen, a prominent landscape architect and planner, to design a model industrial village, named Kistler that was located outside of town. Kistler’s design included a company store and school and various house designs, each with bathrooms, living and dining rooms (Donaldson 2006).

Figure 3. Brickyard and housing in 1910.

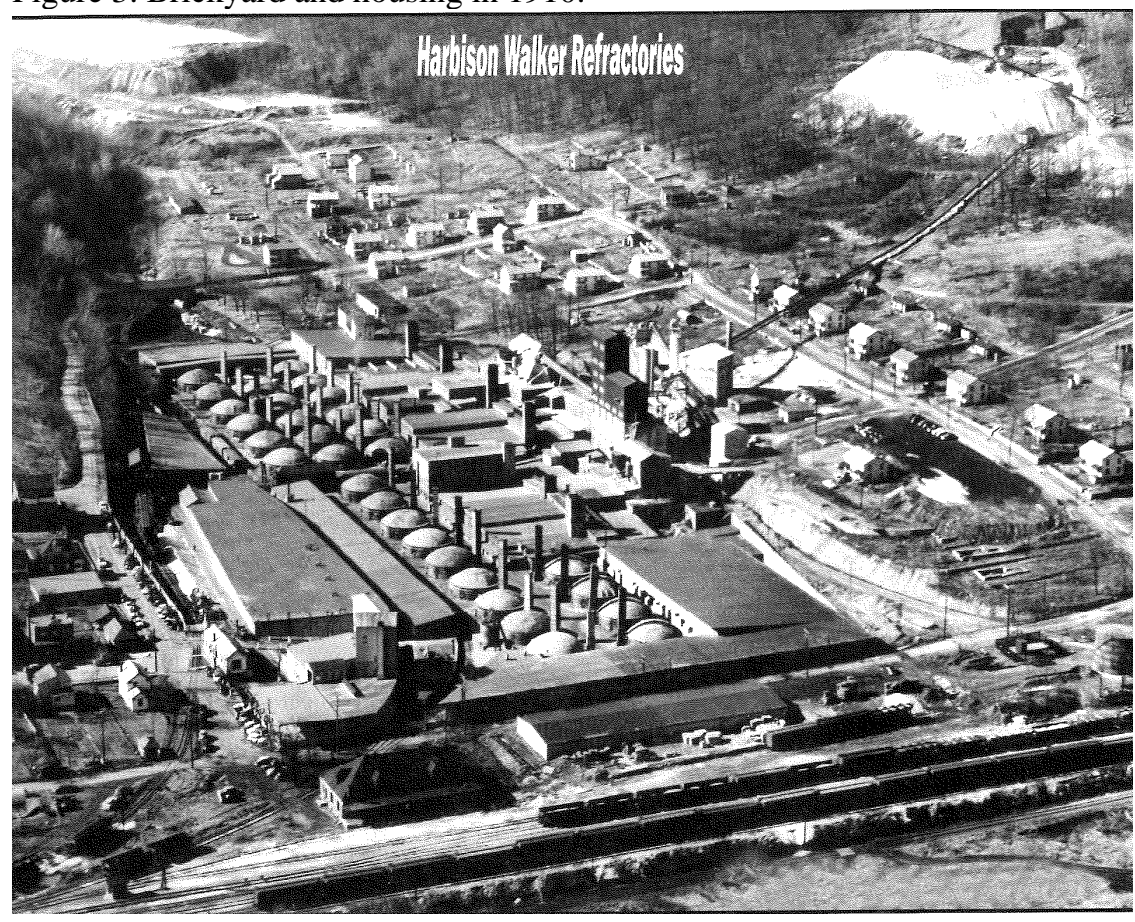

Nolan describes the importance of Kistler to the brickyards and to Mount Union:

"The population being so largely foreign in its make-up, there is distinct necessity for a lead to be giving in the direction of Americanism. This is done in a much better way than by exhortation-by the provision of something tangible, in the form of good living conditions, which more nearly express the ideals of this country”(Wallace 1993, 121).

Nolan's design philosophy was founded on the notion that housing could create and cultivate citizenship and social interaction among the inhabitants. The architecture of this housing was intended to influence the workers toward the desired behavior of a middle 
class, industrious workforce. Nolan was chosen by the North American Refractories Company to design a company town because of his focus on social purpose within his designs (National Park Service 1990b) (see Figure 4). Nolan was known for designing model towns that were stylistically fashionable, but also accompanied by a rationalized social purpose. Nolan believed that informed civic planning and suitable and healthful homes could help cultivate a spirit of citizenship and social life among the inhabitants.

Figure 4. Kistler Housing

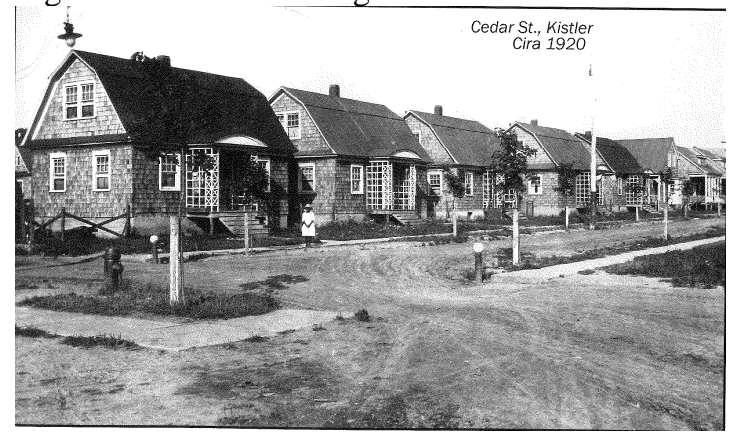

The value of housing as a mode of regulation is specific to the historical, economic, and social context of the Mount Union refractories industry. The physical design of the company housing was dictated by the specific conditions and context of Mount Union’s labor force (Peck and Tickell 1995). While local labor markets are dominated by regional, state, national, or global trends they are unique in how they each represent a "geographically specific institutionalization of labor market structures conventions and practices, providing unique contexts against which the strategies of labor market actors are formulated” (Jessop 2008, 572). Company housing constructed in Mount Union was designed to manage the influx of non-locals that had diverse backgrounds, cultures, and lifestyles. The more conformed and uniform the labor, the more efficient and productive the company could be (Wallace 1993). In the case of 
Mount Union, the local labor market was largely immigrant or non-local, and to maintain the production levels needed to meet demand for refractory bricks workers needed to be compliant, efficient, and productive. The way that each company implemented their mode of regulation varied, in some cases housing was designed to encourage and uplift the worker and in other cases intended to imply a supervisory role. In either case company housing served the purpose of securing a stable work force for the period when it was most crucial to the refractories industry (National Park Service 1990b)

The physical framework for the houses for guiding social and home life was complemented by extensive educational and social welfare programs and a strict moral policy instilled by the brickyard companies. The large number of immigrants and outsiders, with different languages, backgrounds, and ways of life, coming to work in Mount Union brought the potential for conflict. The response of the brickyards and community organizations was to make the immigrants and outsiders socially uniform. (Wallace 1993). This was done by Americanizing them and "uplifting” their lifestyle to match that of the middle American working class. For example, social guidance was provided in the form of policy which curtailed alcohol consumption and rowdy behavior (National Park Service 1990).

Kistler village and Mount Union’s American Red Cross organization also provided instruction intended for the women of the family in domestic skills such as sewing, fancy work, and cooking (National Park Service 1990b). These social programs reinforced the traditional gender idealogy regrarding the socially acceptable roles for men and women in the American society with women as the homemakers and men as the wage earners(Bell and York 2010). These social norms have historically forced 
households in capitalist economies, and industrial economies in particular, to subsidize production thorugh the unpaid work of women. Women's domesitc responsiblities that include cooking, cleaning, childcare, which are necessities for a productive and consistent laborforce, go uncompensatied in the name of appropriate gender roles, allowing for capitalism and industrial production to remain profitable. As Dunaway states,"If capitalists compensated women for all their externalized costs and unpaid labor, prices would be driven up so high that most commodities would not be competitive in the world economy (2001 pg 22).” While these social norms were by no means unique to Mount Union, the brickyards reinforced this gender ideology with their social programs that targeted improved domestic labor and skills (Bell and York 2010) (Dunway 2001). Social guidence and rules that reinforced gender roles and American social ideals as a mode of regulation allowed for the stability of the workforce and affordable labor costs so that production and capital accumulation could be maintained.

The relationship between work and community is a fundamental dynamic of social organization. Mount Union's community drastically changed when the brickyards increased production, and required a larger labor force. During this period of industrial development, the economy and related growth of the town were under the control of the national brickyard companies and a main focus of operations was on the need for a large and stable workforce. Since the majority of workers were non-locals the stability of the labor force was at risk. Varying strategies of regulation occur around the particular contradictions and conflicts which emerge from social and economic changes (Marini and Mooney 2006). The strategy of providing housing, social programs, and instilling social policies was used as a mode of regulation by the brickyards. Community is the 
setting for social action and a place to explore how economic forces create and recreate the practices and relationships of daily life (Faulk et al. 2003). Mode of regulation refers to the multiple social, cultural, and institutional supports that come together to promote economic growth. Essentially, the brickyard companies constructed a community where they either created or controlled the social, cultural, and institutional supports needed for economic expansion and stability. During this time of expansion and construction, Mount Union was considered the silica capital of the world and maintained this status for over twenty years.

\section{Mount Union: Industrial Economic Decline of the brickyards}

New technology based on silica and the need for refractory brick for steel production increased the consumption of bricks in the early 1900s and peaked about 1926. As the market grew, efforts to cut production expenditures focused on cutting high labor costs through mechanization of the brick refractories. Reducing brick manufacturing to a mechanized process did not occur linearly or quickly and involved a piecemeal of chemical and mechanical analysis (Wallace 1993). Various parts of the manufacturing process were explored to simplify and expedite the many components of the brick formation operation. The evolution of brick making from an intensive hand labor to a primarily mechanized process was a slow transformation (Wallace 1993) (National Park Service 1990a) (PennState Department of Landscape Architecture 1995). In 1912, a group of twenty manufactures formed a trade association which later became the American Refractories Institute. Company leaders wanted increased production and deceased reliance on labor and agreed to industry cooperation and information sharing. This was in contrast to the practice of secrecy and guarded in-house 
knowledge that dominated refractory company procedures in the past. This association promoted the standardization, scientific testing, and research of brick production. Manufacture's agreed to adopt standard brick shapes and testing procedures to measure refractories resistance and wear under various conditions, which gradually reduced a company's dependence on the accumulated skill and experience of individual workers. (Wallace 1993) (National Park Service 1990b).

Mechanization of refractories was developed to meet the need for silica brick; however, mechanization reached these industries after the demand peaked (National Park Service 1990b). Throughout the late $19^{\text {th }}$ century, refractories produced either fire-clay or silica bricks, each with a different chemical composition and manufacturing process. In the early $20^{\text {th }}$ century, the chemical composition of bricks became a focus of the standardization movement in industry. Basic refractories, with a basic chemical composition were developed to be used in open-hearth fire clay and replaced the acid refractories of fire clay and silica. The use of basic brick in the open hearth furnace, a key component in steel manufacturing, was an indicator that demand for silica brick would not return to its 1926 peak (Wallace 1993).

The regulation approach often focuses on the period of capital accumulation and stability, overlooking periods of crisis and change (Goodwin 2006). A new wave of the regulation approach calls for a localized understanding of periods of crisis and strategies that emerge as a response to these changes. Since regulation is a social process, regulation itself is also dynamic and prone to contradictions and crises. Any given regulatory mix will be effective only for a period, as was the case with Mount Union's brickyard refractories. 
The downfall of Mount Union’s brick industry primarily occurred due to economic and industrial forces outside the realm of control of the Mount Union brickyard owners or workers. Within the brick industry, two factors are understood to have contributed to refractories demise, the decline of the United States steel industry and the improving quality and changing technology of production through chemical standardization and mechanization. Standardization made many original products supplied by the refractories obsolete or unneeded (White 1928) (Wallace 1993). Plant closings and layoffs began in the mid 1920s and continued until the industry was all but obsolete in the 1980s (PennDOT District 9 1988). The overall mechanization and standardization of production were part of a larger cultural and economic change occurring in the United States, namely the deindustrialization of nation's industrial heartland (Bluestone and Harrison 1982).

A central understanding to the regulation approach is that contradiction and crisis are inherent to capitalism (Hoggart 1996) (Munton 1995). The new wave of regulation approach focuses on how these contradictions and crises materialize in specific, local contexts and how the established norms, practices, and ideologies of certain local modes of regulation are destabilized and delegitimized during periods of contradiction and structural crisis (Drummond et al. 2000). Although the cause of Mount Union's economic change and crisis was on a larger, national scale, it produced a local response. This structural crisis led to the strategies of divestment and elimination of company housing and an ending of social programs in order to remain solvent (High 2003). The modes of regulation of housing and social programs were seen as an unnecessary business expense 
by the brickyards, delegitimizing the structure on which Mount Union’s brickyard culture and industry was built.

Investment, infrastructure, and capital brought by the refractories industry significantly changed the social and economic foundation of the town. The vast economic prosperity of Mount Union in the late $19^{\text {th }}$ and early $20^{\text {th }}$ centuries came from outside companies, which foresaw profitability in Mount Union's location and abundance of raw material for silica brick manufacturing. When the demand for refractories declined and the need for labor was lessened, the deindustrialization or the "widespread systematic disinvestment” of the industry occurred (High 2003). A main response to industry decline in Mount Union was in the disinvestment of company housing:

"Houses are not usually considered as industrial objects, yet they were clearly planned and constructed as part of the industrializing effort, and they were dismantled or disowned much like other plant property during deindustrialization” (National Park Service 1990b, 34).

Mount Union’s company housing was eliminated in two ways during the "streamlining movement” of deindustrialization and divestment. In 1944 North American Refractories sold houses in Kistler, but continued the manufacturing operation. General Refractories sold the houses it owned within the town of Mount Union and closed the brickyard. The houses next to the plant were demolished and the brickyard site became the property of the town (Donaldson 2006). Harbison-Walker “re-evaluated” their real estate holdings in the early 1950's and demolished the entire Ganister Hill neighborhood as part of their plant modernization. The houses were so well integrated into the brickyard setting, intended to easily combine work and home life, when labor and production needs were great and now these houses were seen as interfering with access and manufacturing of 
bricks (Wallace 1993). The mode of regulation of company housing that embedded the social, cultural, and economic aspects of life for the purpose of facilitating capital expansion had lost its usefulness. This established mode of social regulation which served to maintain the "regime" of large industrial companies was now inappropriate for the economic future of Mount Union.

The Mount Union brickyard companies' strategies to remain in production were largely unsuccessful. General Refractories Company closed its doors in the 1950s at the same time they sold their housing. Harbison-Walker remained in production through 1985 with only 25-40 employees compared to 563 employees at peak production, that year they announced the closure of operations because the silica brick market had "virtually collapsed". North American Refractories, with even less employees, closed in March of 1990 (Donaldson 2006). The brickyard industry which was so fundamental to the industrial development of the Mount Union community was now obsolete.

\section{Conclusion}

While processes of capital accumulation are increasingly global, modes of regulation are formed within a local environment and are thus different and distinctive based on the regional and historical situation. The regulation approach analyzes the unique framework and effects of particular modes of regulation as they operate across rural areas (Goodwin 2006). In this case, the local environment is the rural community of Mount Union, Pennsylvania (Goodwin 2006) (Peck and Tickell 1995) (Uffer 2008).

Company towns were constructed as an extension of the industrial machine to control labor and production by setting the framework of social organization. To meet consumer demand, the brick companies of Mount Union and other Pennsylvanian 
brickyard towns rationalized and logically included housing, schooling, and social programs and policies as part of their production costs. The companies' decision to eliminate housing was in response to changes in economic conditions, management, and operating polices that had made them extraneous pieces of brickyard machinery and in turn delegitimized their existence. The brick companies’ corporate interests took priority over the local community's social and economic lives which were tied to the brickyards. With company housing destroyed, the social and cultural ties to brickyard work were diminished.

Brickyard companies in Mount Union used company housing and social programs as a mode of regulation. Company housing was designed as a way to gain control over the large amount of labor, socialize an immigrant and culturally diverse workforce, and to ensure that production was as smooth and efficient as possible. Housing was recognized as an extension of the machinery and industrial holdings of the brickyards. Potential conflicts between different social and cultural groups that could halt or inhibit production were minimized using the control of housing and social programs. This management strategy assisted in the industries' expansion and capital accumulation for many decades.

Deindustrialization hit the Pennsylvania brick industry hard. Mechanization and the decline of the nation's steel industry limited the need for bricks and the labor used to produce them. This economic crisis caused a localized response, specific to Mount Union's brickyards. Using the regulation approach, the elimination of company housing and social programs illustrates the specific strategies and local context used by the brickyards to sustain capital accumulation. When refractory brick production was profitable and bricks were in demand, the industrial leaders used housing, social 
programs, and reinforcement of gender roles as modes of regulation that combined the social, cultural and institutional supports to sustain and promote economic growth. When the brick industry no longer required a large amount of labor and the demand for refractories brick fell, company housing was sold and social policy was abandoned in order to remain solvent. By eliminating company housing, the brick companies’ responsibility and involvement in the social and cultural foundations of the community were gone.

When a mode of regulation can be identified the regulation approach provides an explanation of its process including the operation, success, and eventual decline. In the case of this research, company housing and social programs were implemented as a management strategy by the brickyard companies. This analysis allows for an assessment of the effectiveness of regulation in different places and different times. The regulation approach is a method which helps explain why specifics and details of how capitalism occurs vary in time, space, and place, while its essential characteristics needed for capital accumulation remain constant. 


\section{Work Cited}

Bell, Shannon and York, Richard. 2010. "Community Economic Identity: The Coal Industry and Ideology Construction in West Virginia.” Rural Sociology 75: 111143.

Bluestone, Barry, and Harrison, Bennett. 1982. The Deindustrialization of America: Plant Closings, Community Abandonment, and the Dismantling of Basic Industry. Basic Books, Inc. Publishers. New York, New York.

Broomhill, Raymond. 2002. The limits of capitalism: “An approach to globalization without neoliberalism.” Canadian Journal of Development Studies-Revue Canadienne D Etudes Du Developpement 23: 168-171.

Chittenden, Wendy and A. Luloff. 1984. "Rural Industrialization: A Logit Analysis.” Rural Sociology 49.

Cloke, Paul, and Goodwin, Michael. 1992. "Conceptualizing Countryside Change: From Post-Fordism to Rural Structured Coherence.” Transactions of the Institute of British Geographers, New Series 17 (3): 321-336.

Donaldson, Bryan. 2006. Brick Town USA: Mount Union PA.

Drummond, Ian; Campbell, Hugh; Lawrence, Geoffrey; and Symes, David. 2000. “Contingent or structural crisis in British agriculture?” Sociologia Ruralis 40.

Dunaway, Wilma. 2001. "The Double Register of History: Situating the Forgotten Woman and Her Household in Capitalist Commidity Chains.” Journal of World Systems Research 7: 2-29.

Falk, William; Schulman, M; and Tickamyer, Ann. 2003. Communities of Work: Rural Restructuring in Local and Global Contexts. Athens, OH: Ohio UniversityPress.

Goodwin, Michael. 2006. “Chapter 21. Regulating Rurality?” In the Rural studies and the regulation approach. Handbook of Rural Studies, edited by Paul Cloke, Terry Marsden, and Patrick Mooney SAGE, London, Sage Publications.

Goodwin, Michael, and Painter, Joe. 1996. "Local governance, the crises of Fordism and the changing geographies of regulation.” Transactions of the Institute of British Geographers 21: 635-648.

Goodwin, Michael, Paul Cloke, and P. Milbourne. 1995. ”Regulation Theory and Rural Research Theorizing Contemporary Rural Change.” Environment and Planning A 27: 1245-1260. 
High, Steven. 2003. Industrial Sunset: The Making of North America’s Rust Belt, 1969-1984. University of Toronto Press. Toronto Canada.

Hoggart, K. 1996. Reconstituting rurality: Class, community and power in the development process - Murdoch, J, Marsden,T. Journal of Rural Studies 12: 9192.

Huntingdon County 1978. Huntingdon County Historic Sites Survy Preliminary Report.

Jessop, Bob, Tod Rutherford, and Jamie Peck. 2008. "Peck, J. 1996. Work-place: the social regulation of labor markets. New York: The Guilford Press - Commentary." Progress in Human Geography 32: 574-577.

Jessop Bob. 1997. "Twenty years of the (Parisian) regulation approach: the paradox of success and failure at home and abroad.” The New Political Economy 2: 503-506

Jessop, Bob. 1997a. "Survey article: the regulation approach. “Journal of Political Philosophy.

Knudsen, Daniel; Koh, Taekyung; and Boggs, Jeffrey. 1997. Assessing the Regulationist View of History: An Analysis of Employment Change in America, 1940-1989. Economic Geography. 73: 371-389.

Madroudeas, Stavros. 1999. "Regulation Theory: The Road from Creative Marxism to Postmodern Disintegration.” Science and Society 63 (3): 310-337.

Marini, Matteo and Mooney, Patrick. 2006. Chapter 4: Rural Economies. In the Rural studies and the regulation approach. Handbook of Rural Studies, edited by Paul Cloke, Terry Marsden, and Patrick Mooney SAGE, London, Sage Publications. Handbook of Rural Studies. London, Sage Publications.

Mulrooney, Margartet. 1991. A Legacy of Coal: The Coal Company Towns of Southwestern Pennsylvania. Perspectives in Veracular Architecture 4: 130-137.

Munton, Richard. 1995. Regulation Rurla Change: Property Rights, Economy and Environment: a Case-study from Cumbria, UK. Journal of Rural Studies 11: 269-284.

National Park Service. 1990a. Historic American Buildings Survey Refractories Company Towns HABS No. PA-5547. U.S. Department of the Interior. Washington D.C.

National Park Service 1990b. Historic American Buildings Survey Mount Union Vicinity ABS No. PA-5573. U.S. Department of the Interior National Park Service. Washington D.C. 
National Park Service 1990c. Historic Resource Survey Huntingdon County. Washington D.C. U.S. Department of the Interior National Park Service.

Page, Brian and Richard Walker. 1991. From Settlement to Fordism - The Agroindustrial Revolution in the American Midwest. Economic Geography 67: 281-315

Painter , Joe and Goodwin, Michael. 1995. Local governance and concrete research: Investigation the uneven development of regulation. Economy and Society. 24: 334-356.

Peck, Jamie and Tickell, Adam. 1995. The social regulation of uneven development: regulatory Deficit, England's South East and the collapse of Thatcherism. Environment and Planning A. 17: 15-40

PennDOT District 9, a. F. H. A., and Boswell Yule Jordan Engineering. 1988. Phase II Archaeological Investigation. Mount Union Bypass Project, T.R. 522 L.R. 121, Section 001. Huntingdon County PA.

PennState Department of Landscape Architecture 1995. The Cultural Landscapes of the East Broadtop Railroad. College Park PA: Pennsylvania State University

Roth, Dennis 2000.Thinking about Rural Manufacturing. A Brief History. Rural America. 15 (1)

Southwestern Pennsylvania Heritage Preservation Commission (SPHPC) 1993. Concept Plan for the Southwestern Pennsylvania Industrial Heritage Route. Department of the Interior National Park Service.

Uffer, Sabina. 2008. Understanding Shrinking Processes- What can Regulation Theory Tell us? London School of Economics and Political Science.

U.S. Department of the Interior.1994.Western Pennsylvania Region: Its Landscape, People, and Industry. Southern Pennsylvania Heritage Preservation Commission.

White, Langdon 1928. The Iron and Steel Industry of the Pittsburgh District. Economic Geography 4 (2).

Wilson, Lisa. 2004. Riding the Resource Roller Coaster: Understanding Socioeconomic Differences between Mining Communities. Rural Sociology 69: 261-281.

Wallace, Kim. 1993. Brickyard towns: A History of Refractories Industry communities in South-Central Pennsylvania. U.S. Department of the Interior Natural Park Service. 


\section{Chapter 2.}

This chapter was completed in the APA style for publication in Progress in Planning journal.

\section{The Local Economy of a Rural Pennsylvania Community: Targeting Regional Economic Development, a Quantitative Analysis.}

\section{Introduction}

Early economic development policy efforts in the United States, dating back to colonial times, centered on national development. Sub-national and regional economic development came after WWII and focused largely on recruitment and a simplistic approach to economic strategy where all jobs, industries, and employment types were pursued. Critics claimed that these strategies were often politically driven with short term gains and lacked the planning and forethought required to benefit the community long term (Deller et al 2009). Economic and community development policy approaches have since evolved as the understanding of growth and development processes have changed (Deller et al 2009). Previously, studies of economic competitiveness and growth focused on the national scale when shaping policy, measuring economic prosperity, and determining economic drivers. Currently, economic development analysis and initiatives at regional and sub-national levels are now considered integral and critical to understanding the economy at all scales (Porter 2003; Romanelli and Khessina 2005). Michael Porter, a leader in economic development studies, states that

“Competitiveness is rooted in a nation's microeconomic fundamentals, manifested in the sophistication of its companies and the quality of its microeconomic business environment “(Porter 2003).

Regions are complex and include multiple types of activity and interaction existing within several levels of geography including cities, counties, states or provinces, and 
nations. Targeted Regional Economic Development (Goetz et al 2009) has been utilized by both economists and economic development practitioners to analyze regional economies, guide policy decisions, and apply tools that will facilitate informed economic development planning. Targeted Regional Economic Development (TRED) focuses on how insights into the regional structure and processes of the local economy can help communities expand or sustain existing businesses and promote new businesses through entrepreneurship and targeted planning. Well developed analysis can help focus efforts and understanding of the fundamentals of local economies and help decision makers choose economic strategies that are potentially the most productive to the regional economy in the long run. The analytical tools available for practical and usable targeting purposes range from techniques whose calculations require simple input to in depth models that utilize detailed economic information.

Contemporary research has shown that there are considerable differences in process, performance, and growth in economies across regions and throughout all nations. Regional economies vary widely in terms of economic performance measures such as wages, wage growth, and employment. The national economic system encompasses all of these varied levels of regional performance, signifying that many crucial determinants of national economic outcomes occur at the regional level (Porter 2003). In short, regions matter in the understanding of complex economic processes. In order to understand the economic prospects of nations it is necessary to employ a bottomup, microeconomic approach.

Techniques such as Location Quotient and Shift Share analysis require data that can be collected through the United States Census or Bureau of Labor Statistics. The 
calculations are simple, allowing communities with limited resources accessibility to these tools. The Location Quotient and Shift Share analysis, techniques used as part of this case study, are part of Economic Base Theory. This theory centers on the assumption that the local economy can be divided into two very general sectors, the basic sectors, which are export based and drive the local economy, and non-local sectors, those that supply primarily local needs. Although simple in procedure, the Location Quotient and Shift Share tools provide insight into the basic structure of the local economy, competitive advantage, and performance in relation to other economies such as the state or nation and are widely used by local planners and economists. (Blakely 1994; Chapin 2004; Goetz et al 2009).

More advanced economic modeling tools are useful in understanding the local industrial linkages and conditions of the economy; however, they require more resources and data, limiting the communities that can utilize them. Communities with access to these tools, and modeling capabilities needed to perform more advanced analysis then they can use this information to help better target possible development opportunities. Input Output analysis, conducted within this case study, is used to model a local economy's industries. A central principle of Input Output analysis is the identification of inter-industry linkages that can be used to identify gaps and disconnects between the products and goods that industries export and import for final production (Minnesota Implan Group 2011). The information gained from this analysis can be used to identify industries that are importing goods and services already locally produced, or to examine the possibility of targeting industries for development that may be able to produce goods needed by local industries for production (Delta Development Group 2003). The 
techniques described above are tools used in this study to provide economic information for the case study area of Huntingdon County, Pennsylvania.

The positive analyses methods chosen for this study, while very useful for a basic background, understanding, and structure of local economic conditions, are descriptive and do not include community input as surveys or interviews may. Caution must be used when deriving interpretations from these methods as they were devised for national scale analysis or larger regions than local economies (Deller 2009). Despite these limitations, the Location Quotient, Shift Share, and Input Output techniques provide details of the local industrial composition of the economy, help examine how the local economy relates to or are influenced by larger economies such as the state or nation, and expose gaps in the local imports and exports that can be possible targets for economic development (Shaffer 1999). The object of this research is to understand the underlying economic reality of Huntingdon County in order to assist residents and planners to better gauge how to reach the economic goals and visions of the region. For instance, Huntingdon County's comprehensive plan of 2003 states, as one of its recommendations and visions developed by citizens, planners, and businesses, that the county should target major industrial-commercial development into high quality sites (Huntingdon County 2007). The techniques used within this study can help with their development goals by identifying the following: county industries that are competitive, growing, or in demand; national and state economic trends that may influence the success of new regional industries; and possible import and export gaps within the local industrial structure.

These techniques were chosen for several reasons that include: compatibility of data between techniques; data access and availability of modeling resources; and the 
knowledge and skills of the researcher. The economic base tools of Location Quotient and Shift Share analysis provide information on the local economic conditions of Huntingdon County and its industrial structure, competitiveness, and relative position to the state and national economy. This information is complementary to the gap analysis performed with input-output modeling. The data used for this case study, both employment data used for the base techniques and inter-industry information for the Input Output analysis, were provided through IMPLAN ${ }^{\circledR}$, accessed through the Pennsylvania State University.

The first section of this paper provides a background and overview of the Huntingdon region and economic setting. The second section of this paper focuses on two methods of economic base modeling, Location Quotient and Shift Share analysis. These tools provide a descriptive analysis of Huntingdon's economic structure involving simple calculations and providing insight to the local economy relative to the national economy. The results of these methods are discussed throughout this section. The third section of the paper builds on these basic techniques with a gap analysis and import substitution study using Input Output analysis to identify industries which the community may want to focus attention on for further action. This type of analysis uses IMPLAN ${ }^{\circledR}$ Input Output modeling data and examines industry interconnectedness (MIG 2011). The fourth section of this paper discusses recommendations and planning implications, based on the findings of the research methods, for Huntingdon County. Limitations of the research are also discussed. The conclusion summarizes the methods used for the Targeted Economic Regional Development (TRED) analysis of Huntingdon County and how this economic research can benefit the community. 


\section{Huntingdon County Region}

The purpose of this study is to utilize specific techniques to better understand the structure and mechanisms of the rural economy of Huntingdon County, Pennsylvania. This county was selected because of its current economic situation, namely recent consistent high unemployment, job loss, low wages, and weak economic performance in relation to the state and nation. Many rural communities in the United States find themselves in similar circumstances. Analyzing the economic structure to help target viable jobs and industries for these regions is beneficial to communities struggling in hard economic times. For the purpose of this case study, the region is limited to the county level for two main reasons. First, the techniques used for this analysis depend on employment and industry information which is often reported at the county level. While it is understood that the local economy and industry interaction extend beyond the county boundary, for the techniques used and data available for this study, analysis at the county level is the most feasible option. Second, the purpose of this study is to provide a realistic economic picture of rural Huntingdon County for the purposes of assisting economic development and community planning decisions. In this rural area, local planning and economic development occur primarily at the county scale. Also, the county level is easily comparable across the state and nation. The analysis used for this paper is meant to be relevant and useful outside the scope of Huntingdon County.

Huntingdon County is located within Central Pennsylvania, in the Northern Appalachian region. This rural Pennsylvania county’s population was 45,915 in 2010 (United States Department of Commerce 2010). With a population gain of .7\%, Huntingdon is lagging behind both Pennsylvania’s growth of 3.3\%, and the national 
growth rate of 9.7\%. Huntingdon's medium household income of $\$ 41,078$ is also below the state and national levels of $\$ 49,737$ and $\$ 51,425$ respectively (United States Department of Commerce 2010). Throughout the last four years, as unemployment nationwide has increased steadily, Pennsylvania has maintained an unemployment rate below 9\% and has been consistently lower than the national unemployment which peaked in 2010 at 9.6\%. However, Huntingdon County’s unemployment rate has been higher than the state average for the last ten years and for the 2010 year is at $10.4 \%$ (United States Department of Commerce 2010; United States Department of Labor 2009). Several factors contribute to Huntingdon County's slow growth, low median household income, and high unemployment compared to both the nation and state. A main contributing factor is the county's high level of employment within the nationally declining manufacturing sector. Manufacturing is highly susceptible to cyclical fluctuations in employment. Huntingdon County's economy has historically been tied to a strong reliance on the manufacturing sector and it continues to be a foundation of the County economy employing $11 \%$ of the local labor force in 2009 compared to $6 \%$ of national labor force.

Much of the manufacturing sectors with high employment in Huntingdon County are declining both nationally and locally. A major contributor to both local and national decline is the North American Free Trade Agreement (NAFTA) of 1994. This trade agreement between the United States, Canada, and Mexico resulted in a large amount of manufacturing leaving the United States (Delta Development Group 2003; Scott 2003). The outsourcing of labor and production to plants outside the United States has become so attractive to companies because many foreign countries offer incentives 
such as low labor cost and reduced environmental considerations that make production more cost effective (Delta Development Group 2003). Since production of goods is so much cheaper outside of the United States, companies can offer products at lower costs, driving up the amount of foreign imports and further lowering the need for U.S. manufacturing. In 2003 Pennsylvania had experienced the seventh-highest job losses of any state due to the NAFTA trade patterns. Estimates reveal that trade with Mexico and Canada from 1994 and 2003 has cost Pennsylvania 38,325 jobs with over 31,000 of these jobs in manufacturing (Keystone Research Center 2003). Huntingdon County was particularly affected because of its close ties to large percentages of workforce in manufacturing. Huntingdon County is recognized by the North American Development Bank (NADBank) as NAFTA impacted, allowing for assistance of the displaced workforce. The North American Development Bank and associated Community Adjustment and Investment Program provide assistance to NAFTA impacted and displaced regions. From 2000 and 2003 over 700 displaced and unemployed workers in Huntingdon County were qualified for NADBank assistance (Delta Development Group 2003).

The high level of employment within manufacturing in Huntingdon County could account for some of the unemployment, as well as slow population growth due to loss of jobs and opportunities. As manufacturing declines both locally and nationally, many rural communities are increasing their service sector employment. Manufacturing employed 25 $\%$ of the labor force in the region in the early 1990s. Throughout the 1990s, the manufacturing industry continued to report job loss that intensified during the recession in 1999. In contrast, the lower paying service sector has become the largest employer in 
the region impacting the average earned income in the area (Huntingdon County 2003). The transition from a resource-based economy, which traditionally relied on farming and manufacturing to sustain growth and employment rates to a service-based economy, has impacted the economic base of this region and could contribute to the lower median wage. The following sections of this paper take a more in-depth look into the economic structure, competitiveness, and industrial make up of Huntingdon County to help illuminate the county’s current economic condition.

\section{Economic Base Theory Methods: Location Quotient and Shift Share}

The following quantitative tools of Economic Base Theory, Shift Share and Location Quotient analysis are used to examine the economic structure of Huntingdon County, Pennsylvania. Economic Base Theory, as previously described, recognizes the county’s economy as an integrated economic unit that performs like a national economy. General economic settings can be accessed through these methods (Blakely 1994). The local economy is depicted as producing, importing, and exporting goods and services. Viable economies export goods, retain significant income, and build linkages within the community that create jobs for local individuals. Economic Base Theory analysis examines the basic, exporting sectors of the economy and looks for the relationships among those components that increase the job and income possibilities for local residents. Shift share and location quotient techniques focus on the size and performance of a local economy in reference to these relationships as well as the community's ability to change its position in the larger economic region (Chapin 2004; Blakely 1994)

The Location Quotient (LQ) is a descriptive tool used to analyze the strengths, weaknesses, specializations, and industrial diversity of the local economy. In comparison 
to a reference economy and this tool helps identify industries that exhibit a strong local concentration and are basic industries. Basic industries are understood to bolster the economy because their markets extend beyond the local area and bring additional business and consumers to the area. The non-basic sectors primarily serve local markets and while these industries do not necessarily promote large growth for the local economy they do present opportunities for the local economy by re-circulating money and providing goods and services need for export production (Shaffer 1999).

The calculation for the Location Quotient is as follows:

\section{$L Q=($ Local Employment in Industry I / Total Local Employment) / (National}

\section{Employment in Industry I / Total National Employment).}

When interpreting the data, a location quotient (LQ) of less than 1 suggests that local employment is less than expected for a given industry indicating that this industry is not meeting local demand for products or services. All of this employment is considered nonbasic. A location quotient that is equal to 1 implies that local employment is exactly what is needed to meet the local demand for an industry's goods and services. This employment is also considered non-basic because there is no exportation of the industry's products or goods. A location quotient of greater than 1 indicates that the industry is selfsufficient and that local employment is greater than expected and local industries export their goods and services to non-local areas. However, while some of the exporting industry is basic not all of industries with a location quotient over 1 are assumed to be basic with the Location Quotient technique.

A second formula must be is applied determine the actual number of basic sector jobs when the location quotient is greater than 1 . The formula for this is: 
Basic Sector Employment = $($ Regional Employment Industry I $/$ National Employment Industry I) - (Total Regional Employment / Total National Employment) X (National Employment Industry I).

In application, location quotients are often used to identify exporting and importing industries. An exporting industry is one where there is a greater share of the industry than meets the local demand for its products and services. This industry exports the extra goods outside of the local economy. The importing region does not have adequate local production levels of a sector and must import to meet local demand (Chapin 2004; Blakely 1999). The Location Quotient (Table 1) and Basic Sector (Table 2) of Huntingdon County aggregated sectors for 2009 are listed below. A more detailed, non aggregated, Location Quotient and Basic Sector spreadsheet is located in Appendix A.

Table 1. Location Quotient

\begin{tabular}{|c|c|c|c|c|c|}
\hline Description & \begin{tabular}{|l|} 
\\
\\
\\
Employment \\
Huntingdon \\
County 2009
\end{tabular} & \begin{tabular}{|c|} 
\\
\\
$\%$ \\
Employment \\
National \\
$\mathbf{2 0 0 9}$ \\
\end{tabular} & $\begin{array}{c}\text { Industry } \\
\text { Employment } \\
\text { Huntingdon } \\
\text { County 2009: } \\
\text { Total } \\
\text { Employment } \\
\text { Huntingdon } \\
\text { County 2009 }\end{array}$ & \begin{tabular}{|c|} 
Industry \\
National \\
Employment \\
$2009 /$ Total \\
National \\
Employment \\
2009 \\
\end{tabular} & $\begin{array}{l}\text { Location } \\
\text { Quotient }\end{array}$ \\
\hline Total & 17,360 & $172,400,746$ & & & \\
\hline Ag, Forestry, Fish \& Hunting & 5.27 & 1.96 & 5.27 & 1.96 & 2.68 \\
\hline Mining & 0.57 & 0.61 & 0.57 & 0.61 & 0.93 \\
\hline Utilities & 0.41 & 0.33 & 0.41 & 0.33 & 1.22 \\
\hline Construction & 7.04 & 5.73 & 7.04 & 5.73 & 1.23 \\
\hline Manufacturing & 11.45 & 6.98 & 11.45 & 6.98 & 1.64 \\
\hline Wholesale Trade & 1.74 & 3.42 & 1.74 & 3.42 & 0.51 \\
\hline Retail trade & 9.65 & 10.26 & 9.65 & 10.26 & 0.94 \\
\hline $\begin{array}{l}\text { Transportation \& } \\
\text { Warehousing } \\
\end{array}$ & 2.72 & 3.22 & 2.72 & 3.22 & 0.84 \\
\hline Information & 0.83 & 1.95 & 0.83 & 1.95 & 0.43 \\
\hline $\begin{array}{l}\text { Real estate \& rental, Finance } \\
\text { and insurance }\end{array}$ & 3.65 & 9.64 & 3.65 & 9.64 & 0.38 \\
\hline Service Sector & 34.98 & 41.43 & 34.98 & 41.43 & 0.84 \\
\hline Government \& non NAIC's & 21.70 & 14.48 & 21.70 & 14.48 & 1.50 \\
\hline Total & 1.00 & 1.00 & & & \\
\hline
\end{tabular}

Source: IMPLAN data and author calculations 
Table 2. Basic Sector

\begin{tabular}{|l|c|c|c|c|}
\hline & & & & \\
\multicolumn{1}{|c|}{ Description } & $\begin{array}{c}\text { Employment } \\
\text { Huntingdon } \\
\text { County 2009 }\end{array}$ & $\begin{array}{c}\text { Employment } \\
\text { National } \\
\mathbf{2 0 0 9}\end{array}$ & $\begin{array}{l}\text { Location } \\
\text { Quotient }\end{array}$ & $\begin{array}{l}\text { Employment } \\
\text { for } \\
\text { aggregated } \\
\text { sectors with } \\
\text { LQ over 1 }\end{array}$ \\
\hline Total & 17,360 & $172,400,746$ & & \\
\hline Ag, Forestry, Fish \& Hunting & 5.27 & 1.96 & 2.68 & 574 \\
\hline Utilities & 0.41 & 0.33 & 1.22 & 13 \\
\hline Construction & 7.04 & 5.73 & 1.23 & 228 \\
\hline Manufacturing & 11.45 & 6.98 & 1.64 & 776 \\
\hline Government \& non NAICs & 21.70 & 14.48 & 1.50 & 1,253 \\
\hline
\end{tabular}

Source: IMPLAN data and author calculations

Huntingdon County has a location quotient (LQ) of higher than 1 for: Ag,

Forestry, Fishing \& Hunting; Utilities; Construction; Manufacturing; and Government \& non-NAICs, indicating that these sectors export goods and services. The Ag, Forestry, Fish \& Hunt sector has the largest LQ for Huntingdon County at 2.68. Table 1 shows there are a relatively large percentage of employment at $5.27 \%$ for the county when compared to national employment of $1.96 \%$. While examining this sector in more detail in Appendix A, it appears a main cause of the LQ is the Livestock farming sub-sector that has a LQ well above 1 at 6.25, accounting for 574 Basic Sector jobs and 3.66\% of the jobs in Huntingdon. According to the Agricultural Census of 2007, sale of livestock account for $86 \%$ of products sold for farms in Huntingdon County and is in the top 20 Pennsylvania Counties for production of poultry, cattle, and calves. In contrast, the Ag Services industry which includes soil services, veterinary services, livestock services, farm labor, and crop has a location quotient of 0.67 , indicating that support for agricultural producers is lacking from local sources.

The second highest location quotient was manufacturing with a LQ of 1.64. When examining this sector in more detail (Appendix A) we can see that Paper Manufacturing has a large location quotient of 14.19 and provides 776 Basic Sector jobs. One of the largest employers for Huntingdon County, MeadWestvaco, is a paper product 
manufacturer. While a select few of the manufacturing sub-sector industries within Huntingdon County do have a LQ of greater than 1, the majority of industries within this sector are below 1. Appendix A also shows that the majority of manufacturing employment for Huntingdon County is limited to five main industries: Non Metal Mineral, Wood Products, Paper Manufacturing, Plastics and Rubber, and Computer and Other electronics. Local manufacturing lacks diversity and when a sector is limited in employment to a few industries it can be more sensitive to downturns in the economy.

While we can draw some basic information from Location Quotient analysis, we must be careful in drawing conclusions. A location quotient of less than one does not mean that the local community should strive for self-sufficiency in that activity. Some imported sectors are not present within the community for reasons that make it implausible to develop or promote economic development in this industry (Wisconsin Madison Extension 2004). The next section uses Shift Share analysis to provide further information on the sectors of Huntingdon County.

\section{Shift Share Analysis: National Share, Industrial Mix Share, Local Share}

Shift Share analysis determines the productivity of the local economy in comparison to a larger base economy. Shift Share analysis evaluates a community’s industries to determine if local economic growth is primarily the result of national trends, industrial structure or local conditions. This analysis demonstrates how a community fits into a larger economic picture. By examining the sources of growth, Shift Share analysis can determine if local conditions are contributing to poor industry performance or if they favor industry growth. Three components to Shift Share analysis: National Share, Industry Mix, and Local Share (Blakely 1994; Delta Development Group 2003). Data 
provided in Appendix A shows disaggregated industry information related to Shift Share analysis and is utilized to demonstrate the calculation and interpretation of each factor of the analysis.

National Share: Huntingdon County and the National Economy

The National Share component of Shift Share analysis examines the local growth or decline that is attributable to growth of the national economy. The National Share calculation assumes that local industries will grow at the same rate as the national economy. First, the growth rate is calculated for all national industries to give the percent employment change from two distinct points in time. In the case of this study, employment change is calculated from the years 2001-2009. Table 3 shows the national as well as Huntingdon County's employment growth at the aggregated industrial level. As the Table 3 shows, Huntingdon County lost employment within the economy for 9 of the 12 aggregated industries and had an overall job loss of $-2.72 \%$ with -486 jobs. National employment growth at the aggregated industrial level grew by $2.17 \%$ and 367,631 jobs although 8 of the 12 aggregated industrial sectors had job loss from 20012009. 
Table 3. County and National Growth Rates

\begin{tabular}{|l|c|c|c|c|}
\hline \multicolumn{1}{|c|}{ Description } & $\begin{array}{c}\text { Employment } \\
\text { Growth / } \\
\text { Decline } \\
\text { Huntingdon } \\
\text { County 2001- } \\
\mathbf{2 0 0 9}\end{array}$ & $\begin{array}{c}\text { Huntingdon } \\
\text { County } \\
\text { Growth Rate } \\
\text { (rounded } \\
\text { to nearest } \\
\text { hundreth) }\end{array}$ & $\begin{array}{c}\text { National } \\
\text { Employment } \\
\text { Growth / } \\
\text { Decline 2001- } \\
\mathbf{2 0 0 9}\end{array}$ & $\begin{array}{c}\text { National } \\
\text { Growth Rate } \\
\text { (rounded } \\
\text { to nearest } \\
\text { hundreth) }\end{array}$ \\
\hline Ag, Forestry, Fish \& Hunting & -237 & -20.56 & $-510,085$ & -13.09 \\
\hline Mining & 74 & 302.89 & 287,746 & 37.43 \\
\hline Utilities & -30 & -29.88 & $-6,303$ & -1.08 \\
\hline Construction & -115 & -8.62 & $-1,086,275$ & -9.91 \\
\hline Manufacturing & -397 & -16.64 & $-4,542,091$ & -27.40 \\
\hline Wholesale Trade & -37 & -10.98 & $-220,583$ & -3.61 \\
\hline Retail trade & -309 & -15.57 & $-638,967$ & -3.49 \\
\hline Transportation \& Warehousing & 73 & 18.36 & $-669,572$ & -10.76 \\
\hline Information & -21 & -12.93 & $-527,397$ & -13.57 \\
\hline Real estate \& rental, Finance and & -301 & -32.24 & $3,002,775$ & 22.06 \\
\hline insurance & 29 & 0.48 & $6,441,769$ & 9.91 \\
\hline Service Sector & 785 & 26.35 & $2,126,614$ & 9.32 \\
\hline Government \& non NAICs & -486 & -2.72 & $3,657,631$ & 2.17 \\
\hline Total & & & & \\
\hline
\end{tabular}

Source: IMPLAN data and author calculations

To calculate the National Share, the observed national growth rate of $(+2.17 \%)$ is

then applied to the base year employment (2001) for Huntingdon County. The resulting number for each Huntingdon County industry represents the employment growth attributable to national economic growth or decline. This equation Growth = (employment in 2009 - employment in 2001) / employment in 2001. Then the National Growth Share is calculated:

NGS = industry employment $X$ natural average growth rate of total employment (Shields 2004; Delta Development Group 2003). Table 4. Shows the National Share calculation for Huntingdon County industries. 
Table 4. National Share

\begin{tabular}{|c|c|c|c|}
\hline Aggregated Sector & $\begin{array}{c}\text { Huntingdon } \\
\text { County } \\
\text { Employment } \\
2001 \\
\end{array}$ & $\begin{array}{c}\text { National } \\
\text { Employment } \\
\text { Growth Rate }\end{array}$ & $\begin{array}{l}\text { National } \\
\text { Growth } \\
\text { Share by } \\
\text { Industry } \\
\text { (rounded to } \\
\text { the nearest } \\
\text { hundreth) }\end{array}$ \\
\hline Ag, Forestry, Fish \& Hunting & \begin{tabular}{l|l}
1,152 \\
\end{tabular} & \begin{tabular}{|l|l}
$2.17 \%$ \\
\end{tabular} & 24.97 \\
\hline Mining & 24 & $2.17 \%$ & 0.53 \\
\hline Utilities & 101 & $2.17 \%$ & 2.19 \\
\hline Construction & 1,337 & $2.17 \%$ & 28.98 \\
\hline Manufacturing & 2,385 & $2.17 \%$ & 51.70 \\
\hline Wholesale Trade & 339 & $2.17 \%$ & 7.34 \\
\hline Retail trade & 1,984 & $2.17 \%$ & 43.00 \\
\hline Transportation \& Warehousing & 399 & $2.17 \%$ & 8.65 \\
\hline Information & 166 & $2.17 \%$ & 3.60 \\
\hline $\begin{array}{l}\text { Real estate \& rental, Finance and } \\
\text { insurance }\end{array}$ & 934 & $2.17 \%$ & 20.24 \\
\hline Service Sector & 6,043 & $2.17 \%$ & 131.00 \\
\hline Government \& non NAICs & 2,981 & $2.17 \%$ & 64.61 \\
\hline Total & 17,845 & $2.17 \%$ & 386.81 \\
\hline
\end{tabular}

Source: IMPLAN data and author calculations

The overall National Growth Share shows that if the local economy was identical

to the national economy, then the Huntingdon County economy should have grown by

386 jobs (Table 4) between 2001 and 2009, instead there was a loss of 435 jobs (Table 3).

This indicates that Huntingdon County's overall economy is not performing as well as

the national average. We can examine the influence of the national economy on the local economy in greater detail by looking at the aggregated sectors. The National Growth

Share by industry (Table 4) shows how many jobs, if the local economy is performing on

par with the national economy, should have been created between the years 2001-2009.

In Huntingdon County the Service sector has the highest National Share out of the twelve aggregated industrial sectors. Table 3 shows that the service sector in Huntingdon County had job growth from 2001-2009 of 29 jobs. If Huntingdon County was growing at the same rate as the national economy then the Service sector should have grown by 131 jobs. While the service sector in Huntingdon County had job growth, it is lagging behind the national average. 
In contrast, the Government and non NAIC's sector had employment creation of 785 jobs from 2001-2009. According to the National Share calculation (Table 4) national trends are attributed to only 64.61 of these jobs, indicating that this sector is performing well above the national average in Huntingdon County. While the National Share provides some insight into how the local economy is performing according to the national average, some questions remain. Why did Huntingdon County's entire economy not receive their "proportionate" share of overall growth? Why did some sectors outperform the national economic trends and others fall behind? An examination of the Industrial Mix Share and Local share may help shed light on these questions.

\section{Industrial Mix Share}

The Industrial Mix Share calculation determines the jobs created as a result of industrial structure, the mix of industries within the national economy. While the National Share calculation shows how Huntingdon County's industries compare to the national economic growth trends on a whole, the Industry Mix Share provides a tool for interpreting growth trends within various industries. This component helps determine if the local economy is weighted toward industries that are growing faster or slower than the national average. To determine the Industrial Mix Share, the national growth rate for a given industry is subtracted from the overall national growth rate. The resulting number is then multiplied by the base year employment to determine jobs created as a result of industry mix. The industrial mix share formula is (Local Employment for the base year (2001) X (Industry's National Growth Rate National Employment Growth Rate). 
These results are summed to give the Industrial Mix Share component for the entire local economy (Shields 2004; Blakely 1994; Delta Development Group 2003). Table 5 shows the industrial mix for Huntingdon County.

Table 5. Industrial Mix Share

\begin{tabular}{|l|c|c|c|c|c|}
\hline \multicolumn{1}{|c|}{ Description } & $\begin{array}{c}\text { National } \\
\text { Growth Rate } \\
\text { by Industry }\end{array}$ & $\begin{array}{c}\text { National } \\
\text { Growth Rate } \\
\text { all Industries }\end{array}$ & $\begin{array}{c}\text { National } \\
\text { Industrial } \\
\text { Growth Rate }\end{array}$ & $\begin{array}{c}\text { Employment } \\
\text { Huntingdon } \\
\text { County 2001 }\end{array}$ & $\begin{array}{c}\text { Huntingdon } \\
\text { County }\end{array}$ \\
\hline Ag, Forestry, Fish \& Hunting & $-13.09 \%$ & $2.17 \%$ & $-15.26 \%$ & 1,152 & -175.81 \\
\hline Mining & $37.43 \%$ & $2.17 \%$ & $35.26 \%$ & 24 & 8.62 \\
\hline Utilities & $-1.08 \%$ & $2.17 \%$ & $-3.25 \%$ & 101 & -3.28 \\
\hline Construction & $-9.91 \%$ & $2.17 \%$ & $-12.08 \%$ & 1,337 & -161.49 \\
\hline Manufacturing & $-27.40 \%$ & $2.17 \%$ & $-29.56 \%$ & 2,385 & -705.17 \\
\hline Wholesale Trade & $-3.61 \%$ & $2.17 \%$ & $-5.78 \%$ & 339 & -19.56 \\
\hline Retail trade & $-3.49 \%$ & $2.17 \%$ & $-5.65 \%$ & 1,984 & -112.17 \\
\hline Transportation \& Warehousing & $-10.76 \%$ & $2.17 \%$ & $-12.93 \%$ & 399 & -51.60 \\
\hline Information & $-13.57 \%$ & $2.17 \%$ & $-15.74 \%$ & 166 & -26.14 \\
\hline $\begin{array}{l}\text { Real estate \& rental, Finance and } \\
\text { insurance }\end{array}$ & $22.06 \%$ & $2.17 \%$ & $19.90 \%$ & 934 & 185.82 \\
\hline Service Sector & $9.91 \%$ & $2.17 \%$ & $7.75 \%$ & 6,043 & 468.13 \\
\hline Government \& non NAICs & $9.32 \%$ & $2.17 \%$ & $7.15 \%$ & 2,981 & 213.06 \\
\hline Total & $2.17 \%$ & $2.17 \%$ & $0.00 \%$ & 17,845 & -379.60 \\
\hline
\end{tabular}

Source: IMPLAN data and author calculations

If the industry is growing faster than the average for all industries at the national

level we would expect some local growth and the Industrial Mix Share component will be positive. If the local economy is growing slower than the national average for all national industries, or is in decline, the industrial mix component will be negative (Shields 2004).

The total Industrial Mix Share component for the county is -379 (Table 5) indicating that Huntingdon County employment composition is tilted towards slower growing sectors and that employment is being lost because of the mix of industries.

Table 5 shows that manufacturing has an industrial mix of -705 for Huntingdon County, signifying that this sector, when compared to the national average, is performing considerably weaker. The Service sector and Government \& non NAICs had the highest Industrial Mix Share components. While the Service sector is growing nationally at a 
fast rate (9.91\%), Huntingdon County’s Service sector is lagging with employment creation at only 29 jobs (Table 3) created from 2001-2009. If the local industrial mix was similar to the national industrial mix, 468 jobs would have been gained. The Government and non NAICS sector faired very well in the local economy compared to national trends. According to the Industry Mix Share (Table 5) if Huntingdon County was similar to the national industrial structure, 213 jobs would have been gained. The local gain was 785 jobs, far exceeding the national average. This large gain can be attributed to the two State Correctional Institutional prisons located within the county, employing state government workers. According to Huntingdon County Business and Industry, in 2009 the prison system was the top employer for the county. While this employment gain in the Government sector is positive, it is reflecting employment gains in only the prison institution so further employment gains and growth in this sector may be limited.

\section{Local Share}

The Local Share component takes into account the local growth rate of a specific industry. The calculation is based on comparing the local growth rate for the industry to the national growth rate for that industry. The Industrial Mix Share component compares the national industrial growth rate to the national average growth and then applies that to the local industrial structure. In comparison, the Local Share component examines the industrial growth rate at the local level within the calculation, thus comparing local and national industrial growth. This component helps determine the number of jobs created as a result of local competitive advantage. To calculate the Local Share, local industry growth rates are compared with national industry growth rates to identify high-growth industries-industries that outpace national growth rates. The resulting number, the differential, is applied to the base year employment to determine the number of jobs 
created as a result of local competitive advantage. The calculation for the Local Share calculation is:

Local Industry Employment of the Base Year (2001) X (Local Industry Growth Rate -

National Industry Growth Rate). (Shields 2004; Blakely 1994; Delta Development Group 2003). Table 6 shows the Local Share Advantage for Huntingdon County.

Table 6. Local Share

\begin{tabular}{|c|c|c|c|c|}
\hline Description & $\begin{array}{c}\text { Huntingdon } \\
\text { County } \\
\text { Growth Rate } \\
\% \text { (rounded } \\
\text { to nearest } \\
\text { hundreth) }\end{array}$ & $\begin{array}{c}\text { National } \\
\text { Growth Rate } \\
\% \text { (rounded } \\
\text { to nearest } \\
\text { hundreth) }\end{array}$ & $\begin{array}{l}\text { Employment } \\
\text { Huntingdon } \\
\text { County 2001 } \\
\text { by Industry }\end{array}$ & $\begin{array}{c}\text { Local Share } \\
\text { Advantage } \\
\text { by } \\
\text { Huntingdon } \\
\text { Couny } \\
\text { Industry } \\
\text { (rounded to } \\
\text { the nearest } \\
\text { hundredth) }\end{array}$ \\
\hline Ag, Forestry, Fish \& Hunting & $-20.56 \%$ & $-13.09 \%$ & 1,152 & \begin{tabular}{|l|}
-86.04 \\
\end{tabular} \\
\hline Mining & $302.89 \%$ & $37.43 \%$ & 24 & 64.93 \\
\hline Utilities & $-29.88 \%$ & $-1.08 \%$ & 101 & -29.05 \\
\hline Construction & $-8.62 \%$ & $-9.91 \%$ & 1,337 & 17.27 \\
\hline Manufacturing & $-16.64 \%$ & $-27.40 \%$ & 2,385 & 256.59 \\
\hline Wholesale Trade & $-10.98 \%$ & $-3.61 \%$ & 339 & -24.96 \\
\hline Retail trade & $-15.57 \%$ & $-3.49 \%$ & 1,984 & -239.69 \\
\hline Transportation \& Warehousing & $18.36 \%$ & $-10.76 \%$ & 399 & 116.21 \\
\hline Information & $-12.93 \%$ & $-13.57 \%$ & 166 & 1.06 \\
\hline $\begin{array}{l}\text { Real estate \& rental, Finance and } \\
\text { insurance }\end{array}$ & $-32.24 \%$ & $22.06 \%$ & 934 & -507.17 \\
\hline Service Sector & $0.48 \%$ & $9.91 \%$ & 6,043 & -569.87 \\
\hline Government \& non NAICs & $26.35 \%$ & $9.32 \%$ & 2,981 & 507.80 \\
\hline Total & $-2.72 \%$ & $2.17 \%$ & 17,845 & -872.52 \\
\hline
\end{tabular}

Source: IMPLAN data and author calculations

The Local Share can be used to interpret the competitiveness of local business to

the national average. This component indicates how much of the local growth in a

particular industry can be attributed to the local effects or local competitive advantage. If a locality is increasing its share of national employment in a certain industry, then there may be something particularly attractive about the region to firms in that industry that the locality can capitalize on (Shields 2004). As Table 6 shows, the Local Share component for Huntingdon County is -872.52 indicating that the county's economy growing is slower overall than the national economy.

At the aggregated sector level the two largest positive competitive advantages are within Government non NAICS (507.80) and Manufacturing (256.59). As described 
above, a significant amount of the competitive advantage for the Government nonNAICS is based on the location of two state prison facilities within the county. While the employment benefits of the prisons are substantial for the county, future development for local growth and employment within the Government sector are difficult because of the limited and singular nature of the employment associated with this sector in Huntingdon County. The Local Share provides some more information on the Manufacturing sector. The positive number given to manufacturing indicates that this sector has a competitive advantage over that national sector. A closer look at Table 6 tells us that while locally there may be a competitive advantage, manufacturing in Huntingdon County is only declining less than the national average and has no growth associated with it. Manufacturing was also associated with a low Industrial Mix Share, showing that this industry at the national level is declining. Huntingdon County may have a niche or specialized manufacturing that provides an advantage; however, having a large percentage of local employment in this sector may make the county susceptible to further employment loss.

See Appendix A for a more detailed and disaggregated account of the national and local industries. As we can see manufacturing has a large competitive advantage in Paper Manufacturing and Wood Products and unlike many of the manufacturing industries they had a significant gain in employment. According to Huntingdon County's Business and Industry, a packaging and printing company, MeadWestvaco Corporation, was the $4^{\text {th }}$ top employer in 2009 (Huntingdon County Business and Industry 2010). As Appendix A shows, the Paper Manufacturing sector has a high level of employment. This may be an industry that can be developed to have further growth and continue to 
provide jobs for Huntingdon County citizens. Another manufacturing industry, Computer and Other Electronics also has a positive Local Share component (Table 6). However, a closer look (Appendix A) shows that there was also job loss during the study period and this may not be the best industry for the county to focus on.

Table 6 shows the negative Local Share for Service sector employment. It is important to note that the Service sector is top in local employment with $34 \%$ of the workforce employed within this sector. The negative Local Share means that Huntingdon County is heavily employed in industries that are doing much worse locally than they are nationally. A closer look at this sector (Appendix A) shows that the Educational Services industry is performing well below the national average. A significant local job loss of $57 \%$ of employment in this sector compared to a national gain of $37 \%$ is troubling for Huntingdon as $3.7 \%$ of the local workforce is employed within Educational services and may be facing further decline. In contrast the Health Care Services (Appendix A) have a positive local share which is encouraging for the county as J.C. Blair memorial hospital is the $3^{\text {rd }}$ largest employer in Huntingdon County (Huntingdon County Business and Industry 2010).

The Shift Share analysis used above is a descriptive tool rather than a diagnostic one that shows if some industries are more competitive than others but the question why still remains. Several factors may be involved such as access to natural resources local wage rates, workforce productivity, or transportation factors. Shift-Share is beneficial as it examines the sources of changes in local employment growth or decline in terms of national, industrial, or local influence. By examining the root causes of growth or 
decline, Shift Share analysis can help determine if local conditions are contributing to poor industry performance (Blakely 1994)

\section{Input-Output Local Economy Industry Sectors}

The Location Quotient and Shift Share analysis provided some basic information pertaining to local economic structure. The Service sector and Manufacturing sector, the sectors with the highest employment in Huntingdon County, were examined. The InputOutput analysis will allow us to examine these sectors, as well as the other sectors of the local economy, with much more detail. IMPLAN ® information will include employment, wage and salary, production, total income, imports, and exports. This case study uses Input-Output (I-O) modeling through the IMPLAN ${ }^{\circledR}$ computer modeling program to indicate possible industry targets. I-O modeling, described simply, is a type of applied economic analysis that tracks the interdependence among various producing and consuming sectors of an economy. In particular, it measures the relationship between a given set of demands for final goods and services, and the inputs required to satisfy those demands (MIG 2011). By identifying the linkages between local industries that connect suppliers and customers, I-O modeling determines if a local economy is dependent upon a few major employers, or if the local economy is diversified among a large network of related industries.

An expansion of the aggregate, single-equation economic base models such as the Location Quotient and Shift Share analysis, the Input-Output model includes a richer array of economic sectors in the economy. IMPLAN® identifies 440 sectors within the economy, which are unaggregated for this study. The detailed IMPLAN® analysis builds upon the earlier analysis to determine the industries that dominate the local economy and 
to identify potential gaps within the supply chain to Huntingdon County residents and local industries. By identifying gaps, Huntingdon County can use the information in several ways such as; development of a targeted strategy to recruit the types of industries needed to fill the gap; promote local entrepreneurship and small business development to meet the identified needs; support of existing industries to enhance their production and expand their business to meet local demand (Shields et al 2009).

To determine which industries dominate the local economy, four metrics of economic activity are used: total industrial output, employment wage and salary, and total income. While these metrics certainly are not exhaustive, they do provide industry detail that can be used to evaluate important aspects of the local economy. The tables below provide an overview of the top 20 sectors ranked largest to smallest in Huntingdon County in terms of industrial output, employment, wage and salary and total income. Appendix B contains employment information as well as the wage and salary for all industries within Huntingdon County. 
Table 7. Output 2009

\begin{tabular}{|c|l|c|c|}
\hline & & & $\begin{array}{c}\text { \% Share } \\
\text { Output } \\
\text { Huntingdon }\end{array}$ \\
\hline $\mathbf{1}$ & Stationery product manufacturing & $159,457,703$ & 8.96 \\
\hline $\mathbf{2}$ & $\begin{array}{l}\text { Employment and payroll only (state \& } \\
\text { local govt, non-education) }\end{array}$ & $149,764,679$ & 8.42 \\
\hline $\mathbf{3}$ & Electronic connector manufacturing & $119,202,950$ & 6.70 \\
\hline $\mathbf{4}$ & $\begin{array}{l}\text { Imputed rental activity for owner- } \\
\text { occupied dwellings }\end{array}$ & $112,296,654$ & 6.31 \\
\hline $\mathbf{5}$ & Insurance carriers & $63,171,497$ & 3.55 \\
\hline $\mathbf{6}$ & Private hospitals & $54,968,452$ & 3.09 \\
\hline $\mathbf{7}$ & Other plastics product manufacturing & $53,124,031$ & 2.99 \\
\hline $\mathbf{8}$ & $\begin{array}{l}\text { Construction of other new nonresidential } \\
\text { structures }\end{array}$ & $46,664,619$ & 2.62 \\
\hline $\mathbf{9}$ & Food services and drinking places & $44,749,939$ & 2.51 \\
\hline $\mathbf{1 0}$ & Transport by truck & $42,027,740$ & 2.36 \\
\hline $\mathbf{1 1}$ & Wholesale trade businesses & $40,152,962$ & 2.26 \\
\hline $\mathbf{1 2}$ & $\begin{array}{l}\text { Monctary authoritics and depository } \\
\text { credit intermediation activities }\end{array}$ & $36,265,522$ & 2.04 \\
\hline $\mathbf{1 3}$ & $\begin{array}{l}\text { Offices of physicians, dentists, and other } \\
\text { health practitioners }\end{array}$ & $36,110,363$ & 2.03 \\
\hline $\mathbf{1 4}$ & Dairy cattle and milk production & $32,268,650$ & 1.81 \\
\hline $\mathbf{1 5}$ & $\begin{array}{l}\text { Private junior colleges, colleges, } \\
\text { universities, and professional schools }\end{array}$ & $32,260,792$ & 1.81 \\
\hline $\mathbf{1 6}$ & $\begin{array}{l}\text { Electric power generation, transmission, } \\
\text { and distribution }\end{array}$ & $30,520,658$ & 1.72 \\
\hline $\mathbf{1 7}$ & Nursing and residential care facilities & $28,972,391$ & 1.63 \\
\hline $\mathbf{1 8}$ & $\begin{array}{l}\text { Employment and payroll only (state \& } \\
\text { local govt, education) }\end{array}$ & $27,380,474$ & 1.54 \\
\hline $\mathbf{1 9}$ & $\begin{array}{l}\text { Construction of new nonresidential } \\
\text { commercial and health care structures }\end{array}$ & $27,063,465$ & 1.52 \\
\hline $\mathbf{2 0}$ & Sawmills and wood preservation & $25,325,548$ & 1.42 \\
\hline & & \\
\hline
\end{tabular}

Source: IMPLAN data and author calculations 
Table 8. Employment 2009

\begin{tabular}{|c|c|c|c|}
\hline & Description & Employment & $\begin{array}{c}\% \\
\text { Employment } \\
\text { Shares } \\
\text { Huntingdon }\end{array}$ \\
\hline & Total & \begin{tabular}{|l|}
17,360 \\
\end{tabular} & \\
\hline 1 & $\begin{array}{l}\text { * Employment and payroll only (state \& } \\
\text { local govt, non-education) }\end{array}$ & 2,874 & 16.56 \\
\hline 2 & Food services and drinking places & 930 & 5.36 \\
\hline 3 & Stationery product manufacturing & 566 & 3.26 \\
\hline 4 & Nursing and residential care facilities & 549 & 3.16 \\
\hline 5 & $\begin{array}{l}\text { Civic, social, professional, and similar } \\
\text { organizations }\end{array}$ & 545 & 3.14 \\
\hline 6 & $\begin{array}{l}\text { Employment and payroll only (state \& } \\
\text { local govt, education) }\end{array}$ & 513 & 2.95 \\
\hline 7 & Electronic connector manufacturing & 505 & 2.91 \\
\hline 8 & $\begin{array}{l}\text { Construction of other new nonresidential } \\
\text { structures }\end{array}$ & 432 & 2.49 \\
\hline 9 & Private hospitals & 430 & 2.48 \\
\hline 10 & Retail Stores - Food and beverage & 403 & 2.32 \\
\hline 11 & Dairy cattle and milk production & 400 & 2.31 \\
\hline 12 & $\begin{array}{l}\text { Private junior colleges, colleges, } \\
\text { universities, and professional schools }\end{array}$ & 396 & 2.28 \\
\hline 13 & $\begin{array}{l}\text { Offices of physicians, dentists, and other } \\
\text { health practitioners }\end{array}$ & 387 & 2.23 \\
\hline 14 & Private household operations & 352 & 2.03 \\
\hline 15 & Individual and family services & 346 & 1.99 \\
\hline 16 & Retail Stores - General merchandise & 334 & 1.92 \\
\hline 17 & Wholesale trade businesses & 301 & 1.74 \\
\hline 18 & Transport by truck & 288 & 1.66 \\
\hline 19 & Other plastics product manufacturing & 277 & 1.59 \\
\hline 20 & $\begin{array}{l}\text { Construction of new nonresidential } \\
\text { commercial and health care structures }\end{array}$ & 268 & 1.54 \\
\hline
\end{tabular}

Source: IMPLAN data and author calculations 
Table 9. Employee Compensation

\begin{tabular}{|c|c|c|c|}
\hline c & Description & $\begin{array}{c}\text { Employee } \\
\text { Comp. }\end{array}$ & $\begin{array}{c}\% \text { Shares } \\
\text { Wage and } \\
\text { Salary } \\
\text { Huntingdon }\end{array}$ \\
\hline & Total & $557,265,019$ & \\
\hline 1 & $\begin{array}{l}\text { * Employment and payroll only (state \& } \\
\text { local govt, non-education) }\end{array}$ & $131,833,450$ & 23.66 \\
\hline 2 & $\begin{array}{l}\text { Construction of other new nonresidential } \\
\text { structures }\end{array}$ & $29,400,579$ & 5.28 \\
\hline 3 & Private hospitals & $24,429,373$ & 4.38 \\
\hline 4 & $\begin{array}{l}\text { Offices of physicians, dentists, and other } \\
\text { health practitioners }\end{array}$ & $24,102,226$ & 4.33 \\
\hline 5 & Nursing and residential care facilities & $21,462,116$ & 3.85 \\
\hline 6 & Wholesale trade businesses & $16,642,349$ & 2.99 \\
\hline 7 & Food services and drinking places & $15,916,690$ & 2.86 \\
\hline 8 & Stationery product manufacturing & $15,290,829$ & 2.74 \\
\hline 9 & $\begin{array}{l}\text { Private elementary and secondary } \\
\text { schools }\end{array}$ & $14,373,984$ & 2.58 \\
\hline 10 & Electronic connector manufacturing & $13,865,982$ & 2.49 \\
\hline 11 & Retail Stores - Food and beverage & $13,752,657$ & 2.47 \\
\hline 12 & $\begin{array}{l}\text { Private junior colleges, colleges, } \\
\text { universities, and professional schools }\end{array}$ & $11,671,200$ & 2.09 \\
\hline 13 & Individual and family services & $10,192,118$ & 1.83 \\
\hline 14 & $\begin{array}{l}\text { * Employment and payroll only (state \& } \\
\text { local govt, education) }\end{array}$ & $9,474,189$ & 1.70 \\
\hline 15 & Transport by truck & $8,685,287$ & 1.56 \\
\hline 16 & Other plastics product manufacturing & $8,086,632$ & 1.45 \\
\hline 17 & $\begin{array}{l}\text { Civic, social, professional, and similar } \\
\text { organizations }\end{array}$ & $7,989,860$ & 1.43 \\
\hline 18 & $\begin{array}{l}\text { Monetary authorities and depository } \\
\text { credit intermediation activities }\end{array}$ & $7,179,328$ & 1.29 \\
\hline 19 & $\begin{array}{l}\text { Employment and payroll only (federal } \\
\text { govt, military) }\end{array}$ & $6,950,467$ & 1.25 \\
\hline 20 & $\begin{array}{l}\text { Electric power generation, transmission, } \\
\text { and distribution }\end{array}$ & $6,581,082$ & 1.18 \\
\hline
\end{tabular}

Source: IMPLAN data and author calculations 
Table 10. Total Income

\begin{tabular}{|l|l|c|c|}
\hline & \multicolumn{1}{|c|}{$\begin{array}{c}\text { Share } \\
\text { Total } \\
\text { Income } \\
\text { Huntingdon }\end{array}$} \\
\hline $\mathbf{1}$ & $\begin{array}{l}\text { Income } \\
\text { local govt, non-education) }\end{array}$ & $865,113,314$ & \\
\hline $\mathbf{2}$ & $\begin{array}{l}\text { Imputed rental activity for owner- } \\
\text { occupied dwellings }\end{array}$ & $149,764,683$ & 17.31 \\
\hline $\mathbf{3}$ & Insurance carricrs & $62,472,969$ & 7.22 \\
\hline $\mathbf{4}$ & Electronic connector manufacturing & $38,069,365$ & 4.40 \\
\hline $\mathbf{5}$ & Stationery product manufacturing & $31,875,799$ & 4.08 \\
\hline $\mathbf{6}$ & $\begin{array}{l}\text { Employment and payroll only (state \& } \\
\text { local govt, education) }\end{array}$ & $27,380,474$ & 3.68 \\
\hline $\mathbf{7}$ & Private hospitals & $26,340,796$ & 3.16 \\
\hline $\mathbf{8}$ & $\begin{array}{l}\text { Construction of other new nonresidential } \\
\text { structures }\end{array}$ & $20,395,902$ & 2.36 \\
\hline $\mathbf{9}$ & Wholesale trade businesses & $20,231,201$ & 2.34 \\
\hline $\mathbf{1 0}$ & Transport by truck & $19,913,707$ & 2.30 \\
\hline $\mathbf{1 1}$ & $\begin{array}{l}\text { Offices of physicians, dentists, and other } \\
\text { health practitioners }\end{array}$ & $19,424,808$ & 2.25 \\
\hline $\mathbf{1 2}$ & Food services and drinking places & $18,536,638$ & 2.14 \\
\hline $\mathbf{1 3}$ & $\begin{array}{l}\text { Electric power generation, transmission, } \\
\text { and distribution }\end{array}$ & $17,720,614$ & 2.05 \\
\hline $\mathbf{1 4}$ & $\begin{array}{l}\text { Private junior colleges, colleges, } \\
\text { universities, and professional schools }\end{array}$ & $17,184,680$ & 1.99 \\
\hline $\mathbf{1 5}$ & Nursing and residential care facilities & $16,506,985$ & 1.91 \\
\hline $\mathbf{1 6}$ & Other plastics product manufacturing & $15,855,336$ & 1.83 \\
\hline $\mathbf{1 7}$ & $\begin{array}{l}\text { Monetary authorities and depository } \\
\text { credit intermediation activities }\end{array}$ & $15,530,211$ & 1.80 \\
\hline $\mathbf{1 8}$ & $\begin{array}{l}\text { Construction of new nonresidential } \\
\text { commercial and health care structures }\end{array}$ & $12,447,489$ & 1.44 \\
\hline $\mathbf{2 0}$ & Retail Stores - Food and beverage & $11,804,542$ & 1.36 \\
\hline & Retail Stores - General merchandise & $10,567,648$ & 1.22 \\
\hline & & \\
\hline
\end{tabular}

Source: IMPLAN data and author calculations

Industry Output represents the value of industry production. In IMPLAN these are

annual production estimates for the year of the data set and are in producer prices (MIG

2011). Table 7 shows the importance of the Manufacturing sector as well as the State

and Local Government sectors in terms of the level of industrial output within

Huntingdon County. Table 8 and 9 show employment and wage and salary by industry 
for Huntingdon County. It is important to note that the top employer within Huntingdon County, State and Local Government, includes the state prison, which has been identified as the top 10 employers for 2010 (Huntingdon County Business and Industry 2010). It is also important to note that while the Food and Services sector is the $2^{\text {nd }}$ top employer for the county, it is only $13^{\text {th }}$ in terms of wages and salaries. The total income includes the wage and salary plus the following value added income information: proprietary income (payments received by self employed individuals as incomes) and other property type income payments for (rents, royalties, and dividends). While the state prison is still the top provider of employment and overall county income, when the value added information is included with wage and salary, Rental Activity and Insurance Carriers move to the top 20 of total income for Huntingdon. This shows the importance of self employment and rent as total income within the local economy.

Appendix B contains the wage and salary per job for all the industries and places the wage and salary for Huntingdon County on a per jobs basis. This allows us to study how Huntingdon County compares to the nation and state in terms of wage and salary per job. By comparing the top 20 employers Appendix B with the wage and salary per job by industry $\backslash$ Huntingdon County’s wage rates are compared to state and local industries. The top employer for the county, State and Local Government sector is not listed in the top 20 industries in terms of wages. A look at Appendix B shows that this sector is $26^{\text {th }}$ of all county industries and not on par with Pennsylvania or the national wages for this sector. A reason for this could be that for Huntingdon County this sector is comprised mainly of state prison employment which has as lower wage than other state level positions when broken out to a per job basis. A comparison of employment to wage and 
salary per job also show that the Service sector industry, Food Services and Drinking Places, are a large part of Huntingdon's employment. While some service sector jobs such as health care provide a decent wage within the $\$ 35,000-\$ 40,000$ range, Food Services and Drinking, the $2^{\text {nd }}$ top employer within Huntingdon County, provide an average wage of $\$ 14,914$ and is ranked $117^{\text {th }}$ sectors for wage and salary of the local economy.

It is clear by Table 8 that the Manufacturing and Service sector dominate that local economy in terms of employment. However, as previously stated this sector is declining both locally and nationally in terms of employment. In terms of wages and salary per job, the Miscellaneous and Scientific and Technical Services sector, is above the national and state average and ranks 81st (Appendix B) for employment within Huntingdon County. The relatively high average may indicate specialized knowledge and skill of workforce or a demand for skilled workforce within this industry. Huntingdon County may want to explore this sector for investment and development. As discussed in the Location Quotient analysis, the Livestock sector is a relatively large employer within the county. Information in Appendix B indicates that poultry and egg production, a part of the aggregated Livestock sector, pays a higher wage than either the state or the nation. The Mining and Quarrying Sand, Gravel, Clay and Ceramic and Refractory Materials industry also has a higher average county pay rate than either Pennsylvania or the United States but is only $51^{\text {st }}$ in terms of local employment. Huntingdon County historically has had a large presence in clay and ceramic minerals industry and is well known for its desirable ganister, a silica rock desirable for clay and refractory brick production. While presently this sector may not require as large a labor 
force as it did decades ago, these natural resources of Huntingdon are still in demand and the specialized nature of the materials warrant a higher than average wage for the industry. Unfortunately, development and focus on extractive industries may not be in the best interest of Huntingdon County because of the overall national decline in this sector. While this descriptive and detailed look at the sectors within the economy provides background to Huntingdon's economy, an examination of exports and imports may provide further insight into possible targets for regional development within Huntingdon County.

\section{Export and Industry Import analysis}

Export enhancement examines what a region sells to the global market and looks to expand these industries. It is assumed that since the region is already exporting certain industry goods and services, there is a regional comparative advantage in the production of these commodities. The exporting sectors represent an injection of money into the regional economy and are often considered the backbone of the regional economic structure (Wisconsin Madison Extension 2004). While looking at the exports of a regional economy it is important to also study the imports. When industries are importing intermediate goods and services used within their own production, regardless of if they are exporting a final product or service, these are considered a leakage of economic activity from the local economy. This study considers the import leakages with an import substitution analysis. Targeted industry analysis is based on the idea that external suppliers are fulfilling the needs of the local model and that local producers can possibly better meet these needs and diminish the economic leakages (Deller 2009).

Export enhancement and import substitution analysis are often used to determine possible industry clusters on which community can focus. Clusters are geographic 
concentrations of interconnected companies, specialized suppliers, service providers, firms in related industries, and associated institutions in a particular field that compete but also cooperate (Porter 1998). Clusters, more than solitary industries, encompass a variety of linked industries and other goods and services important to competition. An example of these linked industries may be suppliers of specialized machines or services that are not readily available or access to technical information that may help production (Porter 2003; Romanelli and Khessina 2003; Stonehouse and Snowdon 2007). The geographic extent of industry clusters relates to the distance over which the interconnectedness of information, incentives, suppliers, and other efficiencies occur linking the industries within the cluster by commonalities and support. The geographic scale of clusters may include local regions, states, countries, and may involve a group of adjoining or surrounding countries (Porter 2003; Deller 2009; Shields et al 2009).

Table 11 reports the top 20 exports by industry for Huntingdon County ranked from highest to lowest and also include information on intermediate imports, employment, and wage and salary to give some insight into the largest exported industries, the economic base, of the county. Intermediate imports are the imports of goods and services such as energy, materials, and purchased services that are used for the production of other goods and services rather than for final consumption. Table 12 shows the top 20 industries ranked by Intermediate Imports, showing the top imported industries by other industries in Huntingdon County. The intermediate import and export information can provide insights into the degree that an industry's product is being exported and imported into the region. Table 13 examines the Top five imported commodities for Huntingdon County and the industries that imported them. By 
examining the imported commodities in detail we can narrow down the commodities that are being imported into Huntingdon County and examine the possibility of local production.

Table 11. Exports per industry

Top Exports per Industry

\begin{tabular}{|c|c|c|c|c|c|}
\hline & Description & Exports (\$) & $\begin{array}{c}\text { Intermediate } \\
\text { Imports (\$) }\end{array}$ & Employment & $\begin{array}{c}\text { Wage/Salary } \\
\text { Income Per } \\
\text { Job }(\$)\end{array}$ \\
\hline 1 & Stationery product manufacturing & 159052764 & 110383515 & 566 & 43165 \\
\hline 2 & Electronic connector manufacturing & 119129975 & 72591805 & 505 & 58163 \\
\hline 3 & Other plastics product manufacturing & 53037612 & 33002850 & 277 & 36849 \\
\hline 4 & Dairy cattle and milk production & 32008157 & 19547766 & 400 & 5926 \\
\hline 5 & Transport by truck & 21747559 & 15240301 & 288 & 13579 \\
\hline 6 & Sawmills and wood preservation & 21098542 & 13149915 & 127 & 18442 \\
\hline 7 & Insurance carriers & 20376137 & 13130903 & 249 & 57638 \\
\hline 8 & $\begin{array}{l}\text { Construct new residential permanent site } \\
\text { sing }\end{array}$ & 19963596 & 9821857 & 125 & 26855 \\
\hline 9 & Construct other new residential structures & 16581446 & 8028046 & 112 & 26855 \\
\hline 10 & $\begin{array}{l}\text { Private junior colleges- colleges- } \\
\text { universiti }\end{array}$ & 16071151 & 10526074 & 396 & 41976 \\
\hline 11 & $\begin{array}{l}\text { Animal (except poultry) slaughtering- } \\
\text { renderi }\end{array}$ & 15000885 & 7686811 & 34 & 37454 \\
\hline 12 & $\begin{array}{l}\text { All other miscellaneous electrical } \\
\text { equipment }\end{array}$ & 13197293 & 7579283 & 54 & 66667 \\
\hline 13 & $\begin{array}{l}\text { All other chemical product and } \\
\text { preparation ma }\end{array}$ & 12470903 & 8373749 & 22 & 94278 \\
\hline 14 & $\begin{array}{l}\text { Mining and quarrying sand- gravel- clay- } \\
\text { and }\end{array}$ & 12315232 & 4367653 & 71 & 63502 \\
\hline 15 & Mineral wool manufacturing & 12302695 & 5454118 & 34 & 61954 \\
\hline 16 & $\begin{array}{l}\text { Civic- social- professional- and similar } \\
\text { orga }\end{array}$ & 12042091 & 8914233 & 545 & 17370 \\
\hline 17 & Poultry and egg production & 9489428 & 6334668 & 29 & 39215 \\
\hline 18 & $\begin{array}{l}\text { All other miscellaneous wood product } \\
\text { manufact }\end{array}$ & 9250801 & 3358109 & 79 & 20747 \\
\hline 19 & Hotels and motels- including casino hotels & 9059223 & 3052738 & 132 & 16350 \\
\hline 20 & Other animal food manufacturing & 8965594 & 10307841 & 12 & 48942 \\
\hline
\end{tabular}

Source: IMPLAN data and author calculations 
Table 12. Imports per Industry

Top Intermediate Imports per Industry

\begin{tabular}{|c|c|c|c|c|c|}
\hline & Industry & $\begin{array}{c}\text { Total } \\
\text { Exports }(\$)\end{array}$ & $\begin{array}{c}\text { Intermediate } \\
\text { Imports (\$) }\end{array}$ & Employment & $\begin{array}{c}\text { Wage/Salary } \\
\text { per Job (\$) }\end{array}$ \\
\hline 1 & Stationery product manufacturing & $159,052,764$ & $110,383,515$ & 566 & 43165 \\
\hline 2 & Electronic connector manufacturing & $119,129,975$ & $72,591,805$ & 505 & 58163 \\
\hline 3 & Other plastics product manufacturing & $53,037,612$ & $33,002,850$ & 277 & 36849 \\
\hline 4 & $\begin{array}{l}\text { Imputed rental activity for owner- } \\
\text { occupied dw }\end{array}$ & 694 & $22,513,468$ & 0 & 0 \\
\hline 5 & Private hospitals & $4,568,163$ & $21,390,041$ & 430 & 49875 \\
\hline 6 & $\begin{array}{l}\text { Construct other new nonresidential } \\
\text { structures }\end{array}$ & 175 & $21,095,240$ & 432 & 27019 \\
\hline 7 & Dairy cattle and milk production & $32,008,157$ & $19,547,766$ & 400 & 5926 \\
\hline 8 & Food services and drinking places & 418,854 & $17,973,400$ & 930 & 14914 \\
\hline 9 & Transport by truck & $21,747,559$ & $15,240,301$ & 288 & 13579 \\
\hline 10 & Sawmills and wood preservation & $21,098,542$ & $13,149,915$ & 127 & 18442 \\
\hline 11 & Insurance carriers & $20,376,137$ & $13,130,903$ & 249 & 57638 \\
\hline 12 & $\begin{array}{l}\text { Monetary authorities and depository } \\
\text { credit in }\end{array}$ & $1,783,110$ & $12,574,320$ & 208 & 33493 \\
\hline 13 & $\begin{array}{l}\text { Construct new nonresidential commercial } \\
\text { and } h\end{array}$ & 44 & $12,194,998$ & 268 & 26829 \\
\hline 14 & $\begin{array}{l}\text { Offices of physicians- dentists- and other } \\
\text { he }\end{array}$ & 22,237 & $11,673,221$ & 387 & 41142 \\
\hline 15 & $\begin{array}{l}\text { Private junior colleges- colleges- } \\
\text { universiti }\end{array}$ & $16,071,151$ & $10,526,074$ & 396 & 41976 \\
\hline 16 & Other animal food manufacturing & $8,965,594$ & $10,307,841$ & 12 & 48942 \\
\hline 17 & Wholesale trade businesses & $3,951,283$ & $10,290,754$ & 301 & 45629 \\
\hline 18 & $\begin{array}{l}\text { Other state and local government } \\
\text { enterprises }\end{array}$ & 454,474 & $10,224,969$ & 82 & 56926 \\
\hline 19 & $\begin{array}{l}\text { Construct new residential permanent site } \\
\text { sing }\end{array}$ & $19,963,596$ & $9,821,857$ & 125 & 26855 \\
\hline 20 & $\begin{array}{l}\text { Civic- social- professional- and similar } \\
\text { orga }\end{array}$ & $12,042,091$ & $8,914,233$ & 545 & 17370 \\
\hline
\end{tabular}

Source: IMPLAN data and author calculations 
Table 13. Top Five Imported Commodities

\begin{tabular}{|c|c|c|}
\hline \multicolumn{2}{|c|}{ Top 5 imported commodties and importing industries } & \multirow[b]{2}{*}{ Dollars } \\
\hline \multirow{11}{*}{$\begin{array}{l}\text { Imported Commodity } \\
3360 \text { Real estate buying and selling, } \\
\text { leasing, managing, and related services }\end{array}$} & Industries Importing Commodity & \\
\hline & Private hospital services & $7,159,624$ \\
\hline & $\begin{array}{l}\text { Imputed rental activity for owner- } \\
\text { occupied dwellings }\end{array}$ & $5,761,817$ \\
\hline & $\begin{array}{l}\begin{array}{l}\text { Private junior colleges, colleges, } \\
\text { universities, and professional schools }\end{array} \\
\end{array}$ & $3,444,225$ \\
\hline & Stationery product manufacturing & $2,661,044$ \\
\hline & Food services and drinking places & $2,490,914$ \\
\hline & \begin{tabular}{|l|} 
Nursing and residential care facilities \\
\end{tabular} & $2,032,730$ \\
\hline & $\begin{array}{l}\text { Offices of physicians, dentists, and other } \\
\text { health practitioners }\end{array}$ & $1,792,776$ \\
\hline & $\begin{array}{l}\text { Civic, social, professional, and similar } \\
\text { organizations }\end{array}$ & $1,536,292$ \\
\hline & Dairy cattle and milk production & $1,368,820$ \\
\hline & $\begin{array}{l}\text { Other state and local government } \\
\text { enterprises }\end{array}$ & $1,151,857$ \\
\hline \multirow[t]{10}{*}{3105 Paper from pulp } & Stationery product manufacturing & $37,009,099$ \\
\hline & Printing & $1,185,088$ \\
\hline & Newspaper publishers & 503,477 \\
\hline & Other plastics product manufacturing & 215,198 \\
\hline & Food services and drinking places & 176,308 \\
\hline & $\begin{array}{l}\text { All other chem ical product and } \\
\text { preparation manufacturing }\end{array}$ & 99,141 \\
\hline & $\begin{array}{l}\text { Hotels and motels, including casino } \\
\text { hotels }\end{array}$ & 84,731 \\
\hline & \begin{tabular}{|l|} 
Private hospital services \\
\end{tabular} & 54,867 \\
\hline & $\begin{array}{l}\text { Offices of physicians, dentists, and other } \\
\text { health practitioners }\end{array}$ & 26,487 \\
\hline & $\begin{array}{l}\text { Monetary authorities and depository } \\
\text { credit intermediation activities }\end{array}$ & 17,693 \\
\hline \multirow[t]{10}{*}{3319 Wholesale trade distribution services } & Stationery product manufacturing & $10,512,091$ \\
\hline & Electronic connector manufacturing & $4,151,110$ \\
\hline & Dairy cattle and milk production & $1,271,524$ \\
\hline & Other plastics product manufacturing & $1,231,718$ \\
\hline & Food services and drinking places & $1,147,167$ \\
\hline & \begin{tabular}{|l|} 
Wholesale trade businesses \\
\end{tabular} & $1,098,465$ \\
\hline & \begin{tabular}{|l|} 
Sawmills and wood preservation \\
\end{tabular} & 999,750 \\
\hline & $\begin{array}{l}\begin{array}{l}\text { Construction of other new nonresidential } \\
\text { structures }\end{array} \\
\end{array}$ & 905,607 \\
\hline & \begin{tabular}{|l|} 
Private hospitals \\
\end{tabular} & 826,372 \\
\hline & Other animal food manufacturing & 731,267 \\
\hline \multirow[t]{10}{*}{3127 Plastics materials and resins } & Other plastics product manufacturing & $16,159,335$ \\
\hline & Electronic connector manufacturing & $4,734,266$ \\
\hline & $\begin{array}{l}\text { All other chemical product and } \\
\text { preparation manufacturing }\end{array}$ & $1,967,226$ \\
\hline & Mineral wool manufacturing & 530,622 \\
\hline & All other miscellaneous manufacturing & 110,795 \\
\hline & Stationery product manufacturing & 78,776 \\
\hline & Sign manufacturing & 19,975 \\
\hline & $\begin{array}{l}\text { Office furniture and custom architectural } \\
\text { woodwork and millwork manufacturing }\end{array}$ & 12,408 \\
\hline & $\begin{array}{l}\text { Personal and household goods repair and } \\
\text { maintenance }\end{array}$ & 9,440 \\
\hline & $\begin{array}{l}\text { Maintenance and repair construction of } \\
\text { nonresidential structures }\end{array}$ & 4.226 \\
\hline \multirow[t]{10}{*}{3315 Refined petroleum products } & Transport by truck & $4,996,427$ \\
\hline & $\begin{array}{l}\text { Construction of other new nonresidential } \\
\text { structures }\end{array}$ & $2,324,060$ \\
\hline & $\begin{array}{l}\begin{array}{l}\text { State and local government passenger } \\
\text { transit }\end{array} \\
\end{array}$ & $2,042,185$ \\
\hline & \begin{tabular}{|l} 
Dairy cattle and milk production \\
\end{tabular} & $1,806,379$ \\
\hline & $\begin{array}{l}\text { Other state and local government } \\
\text { enterprises }\end{array}$ & 915,765 \\
\hline & $\begin{array}{l}\text { Electric power generation, transmission, } \\
\text { and distribution }\end{array}$ & 905,602 \\
\hline & $\begin{array}{l}\text { All other chemical product and } \\
\text { preparation manufacturing }\end{array}$ & 731,704 \\
\hline & Services to buildings and dwellings & 713,576 \\
\hline & $\begin{array}{l}\text { Construction of new nonresidential } \\
\text { commercial and health care structures }\end{array}$ & 706,402 \\
\hline & Other plastics product manufacturing & 565,346 \\
\hline
\end{tabular}

Source: IMPLAN data and author calculations 
When making input purchase decisions, firms can buy locally or import the needed goods and services into the region. Table 12 and Table 13 help identify industries that are importing a large amount of product in terms of dollar value. Firms that import a large amount of their inputs and do not use local resources may do this for two reasons. First, no local industry that is able to supply the required inputs is considered a gap in the local economy. Second, there is a disconnect that occurs when a local industry exists that could supply the imported input but does not. There could be several reasons for a disconnect such as: a lack of knowledge between the purchasing and selling firms; the analysis is too limited and the industries are buying local and within the immediate region but outside the study area; and there may be a business explanation that is not readily apparent as to why the industries are not using local goods for production (Shields et al 2009).

Table 12 shows that the Stationary Product Manufacturing sector has both high levels of exports as well as high levels of employment and provides a relatively good wage for the region. It is interesting to note that while 159 million dollars worth of Stationary Product Manufacturing is exported into Huntingdon County, other industries import over 110 million dollars worth of this product. Why are there large amounts of Stationary Product manufacturing commodities being brought into Huntingdon County when the local industry produces and exports a large amount of the same commodities? A similar scenario occurs with other industries as well. The top three industries being imported into Huntingdon County, Stationary Product Manufacturing, Electronic Conductor Manufacturing, and Other Plastics Product Manufacturing, are also the top three industries being exported. This indicates that there is a disconnect within 
Huntingdon County in terms of the production of these commodities. A possible cause for this may be that the industries require a particular industrial commodity for production, specific for their industry, but they may not produce this good themselves. For example, the Electronic Conductor Manufacturing sector within Huntingdon County may produce some of the parts for an electronic conductor; however, they may need to import the rest of the specialized parts from the same sector outside the local area to complete production. This would explain why there are both high exports and high imports within these industries. It implies that import levels with the three industries are directly related to the need for production. There may be a gap in the regional economy where a part or electronic piece needed for production of electronic conductors, related to the manufacturing itself, is not produced within Huntingdon County.

Examining Table 13, the $2^{\text {nd }}$ ranked imported commodity, Paper from Pulp, is produced by the Paper and Paperboard Mill industries. This commodity is imported extensively by the highest exporter and a top employer within the region, the Stationary Product Manufacturing industry. According to 2009 IMPLAN data, there are no paperboard, paper, or pulp mills within Huntingdon County. The county may want to consider these industries for economic targeting. While the Shift Share analysis highlights the fact that the Manufacturing sector is declining, focusing efforts on specialized niche manufacturing may be a possibility for the county.

\section{Conclusion}

The Targeted Regional Economic Development (TRED) techniques used within this case study focus on descriptive quantitative analysis relating to the economic structure of Huntingdon County. The objective of this study is for understanding of the 
underlying economic situation in Huntingdon County. An integral part of planning is local input and consideration of community structure and economic standing in relation to local, state, and national economies. The analysis above was created with the purpose to inform and assist the planning process.

Summary of Findings and Planning Implications

While the results of the analysis are specific to Huntingdon County, the general implications hold true for many rural communities in the state. The changes taking place in Huntingdon County reflect a pattern that is consistent throughout rural Pennsylvania. The relevance of this case study is not limited to Huntingdon County but also reflects state trends in the rural economy. The objective of this case study is to represent a realistic view of Huntingdon County's economic situation using the techniques of Location Quotient, Shift Share, and Input-Output analysis. A description of each technique and analysis are explained within this paper. The discussion section for each technique provides the outcome and some possible economic directions that Huntingdon County may want to consider based on these results. While the outcome of this case study does not provide distinct direction for economic development some general policy implications and recommendations can be made.

Recent research shows that manufacturing continues to decline in rural Pennsylvania (Shields 2002). This case study certainly corroborates that information with analysis showing manufacturing job loss at $-16.6 \%$ from 2001-2009. Manufacturing has historically been a more dominant rural industry but the concentration of manufacturing has diminished over the last 30 years. Once a major driver of Pennsylvania rural economies, the manufacturing sector employed 1 in 3 rural workers in 
the late 1960’s. Now less than 1 in 5 rural jobs are within manufacturing. Manufacturing remains a strong basic industry despite both national and local trends of job loss throughout the last ten years. These job losses can be attributed partially to a concentration of employment in sectors that are experiencing sluggish growth at the national level (Huntingdon County 2007).

Huntingdon County’s manufacturing sector is also limited in its diversity $80 \%$ of employment within manufacturing industries are concentrated in five groups which are: Paper Manufacturing; Plastics and Rubber Production; Nonmetal Mineral Production; Fabricated Metal Production; and Computer and Other Electronics. These basic industries are the foundation of Huntingdon County's manufacturing sector which has weathered outsourcing, layoffs, and plant closures in recent years. While these sectors have a strong presence in the local economy, they are struggling to maintain a competitive position in the increasingly global marketplace and are considered mature sectors. Nationwide manufactures have responded to declining demand by limiting hiring and capital investments (Deller et al 2009). The recent recession highlights the importance of economic diversification to the future of the county. In addition, these sectors are typically dominated by a single firm, a situation that does not foster technology sharing, competition, or access to a skilled labor pool (Delta Development Group 2003; Bluestone and Harrison 1982).

A planning strategy that solely focuses upon the retention of the dominant companies fails to address the fundamental problem of many rural communities, dependence upon large organizations with external control as the primary engine for job creation. Instead Huntingdon County should focus on enhancing the local supply chain 
to build competitive advantage within these mature sectors. The supply chain is a network of buyers and suppliers that operate collectively to deliver an end-product to consumers and will vary greatly from industry to industry and between firms. By improving the supply chain the county will create an environment that supports technology transfer and competition (Deller and Goetz 2009). As there is currently no local dominant cluster of industries to model an economic plan, Huntingdon County will need to utilize localized knowledge present in the county's people and institutions as well as the academic and training centers available to be able to enhance the supply chain.

Economic changes such as outsourcing, mechanization, and foreign competition, have rapidly transformed the Pennsylvania rural economy from one centered on the Manufacturing sector to a dependence on the Service industries. As the trend of rural job loss in the manufacturing sector is projected to continue, the service and retail sectors are anticipated to keep posting job gains (Scott 2003). The county’s service sector has witnessed unprecedented growth over the last decade. Although it is still a non-basic sector, it has replaced manufacturing as the county’s top employer. Although many Service sector jobs are high-skill and pay well, some research points to the idea that rural areas may lack the density of population and infrastructure to attract those jobs. As a result, the rural service sector in these areas generates more low-skill jobs (Shields 2002). Because low-skill service jobs pay less on average than low-skill jobs in the manufacturing sector, workers would be worse off economically. Huntingdon County’s second top employment sector in 2009 is Food Services and Drinking Places that on average pay a wage of $\$ 14,914$ (Appendix B). An analysis of annual wages in 
Huntingdon County shows that for every dollar earned within the manufacturing sector, service sector jobs earned 65 cents (Huntingdon County 2003).

The top three industries for growth in rural Pennsylvania between 1990-2000 were all Service sector industries these are: Health Services, Educational Services, and Eating and Drinking places. Expansion within the Health Services sector presents the county's best opportunities for future growth. While there is significant local employment within the relatively well paying Health Services sector, the second highest employer in the county, Food Services and Drinking establishments, ranks 117 in terms of wage and salary for Huntingdon County. Input-Output analysis helped identify sectors that had higher wages and salary per job than state or national levels for that sector. Focus should center on the health care industry which directly will maintain and create jobs but also is a factor in economic development. The health care as a part of quality of life can be critical to a company's decision to locate within a particular community or be able to attract retirees. Statewide the health service industry is expected to have significant growth as an aging population requires increased levels of care (Huntingdon County 2007). Investment and development to retain and attract health care services would benefit Huntingdon County greatly. Huntingdon County’s health services, centered with the JC Blair Memorial Hospital are within close proximity to other regional healthcare facilities such as Altoona and State College (Huntingdon County 2007). The county can utilize these resources to enhance the area's rural health care services and to provide distance learning opportunities for health care professionals.

Overall industry analysis did not identify a strong concentration of industries that is necessary to support a cluster strategy described previously (Porter 2003). Instead a 
targeted strategy should focus on strengthening the county's labor market and diversify their economic base. As a rural community experiencing persistent high unemployment, Huntingdon County needs to utilize federal funding through programs offered by agencies such as USDA Rural Development and the Small Business Association to provide needed infrastructure such improved telecommunications and highway systems to attract prospective businesses as well as tourists. Huntingdon County may also want to focus on services to assist the Agricultural sector. It was identified by using the location quotient technique that the Agriculture sector is underserved with support services, Ag, Forestry, Fishing \& Hunting sector is a basic and is bringing consumers into the economy and expanding the market and support services would help promote growth and money that could be re-circulated within the economy may be lost as agricultural producers are forced to go outside the county for services.

\section{Limitations}

There are great benefits to the type of techniques and methods of economic analysis used for this paper. It is important to consider the limits of these tools when conducting analysis. Despite the popularity of Location Quotient and Shift Share, it is important to consider the limitations of these tools when conducting analysis. Comprehensive LQ analysis may be limited in smaller areas because of lack of data. Both Location Quotient and Shift Share Analysis provide only a snap shot of the time frames involved and may not give an entirely clear picture of the local and national economies because the results are sensitive to the time period chosen. Shift share is limited in that it can provide an overview of national, local, and industrial structure within the economy but it cannot explain the causes of each component. Shift Share 
analysis is a simple technique that fails to account for many factors such as business cycles, identification of why there is an industrial advantage or disadvantage relative to a base economy, and differences caused by industrial detail. When used for industry targeting, the strengths and weaknesses of Input-Output modeling also need to be considered. For instance Input-Output modeling does not recognize capacity constraints. An example of this would be a certain industry is at full capacity but there are constraints to further growth such as limited materials needed for production or a limited available workforce, making this particular industry a poor choice for targeting and development. Input Output would not capture these constraints for further growth within the model. Standard modeling also does not provide information on future growth paths of industrial sectors; they only provide a static view of the regional economy and only current industry growth. The Input-Output, used for industry targeting, is not to be considered an all telling authoritative tool, but instead meant to be used in combination with other methods and most importantly with guidance and information from locals. Information from local developers, citizens, politicians, and business owners will enhance the outcome of industry targeting and help produce worthwhile data from the Input-Output modeling. While there are limitations to Location Quotient, Shift Share, and Input-Output modeling as there are many positives to using these methods for industry targeting. These techniques offer simple, straightforward approaches to understanding the structure of the economy. In order to minimize the effect of the limitations, these techniques should be used in conjunction with other regional analysis techniques and community input in order to develop a more complete representation of the local economy. 


\section{Conclusion}

The methods and techniques of Location Quotient, Shift Share, and Input-Output analysis utilized for this case study provided county specific information on local employment relative to state and national employment, job growth, industry wages and salary, output, total income, and industry imports and export. Since the techniques provide a snapshot in time of the local economy the tools and methods will have to be updated at certain intervals in the future to insure that the representation of Huntingdon County's economy is accurate. The findings derived from the analysis were meant to provide a practical picture of Huntingdon County's economy. These findings can be used in conjunction with community input, direction from economists and planners, and further research to help Huntingdon County reach their economic development goals. 


\section{Work Cited:}

Blakely, E. (1994) Planning Local Economic Development: Theory and Practice Thousand Oaks, California: Sage Publications.

Chapin, T. (2004) Forecasting for Plan Development. Florida State University Department of Urban and Regional Planning. Tallahassee, Florida.

Deller, S. (2009) Import substitution and the analysis of gaps and disconnects. Targeting Regional Economic Development, S. Goetz, S. Deller, and T. Harris (eds) New York: Routledge.

Deller, S., and Goetz, S. (2009) Historical description of economic development policy. Targeting Regional Economic Development, S. Goetz, S. Deller, and T. Harris (eds) New York: Routledge.

Deller S., Leatherman J., and Shields, M. (2009) TRED and an educational tool.

Targeting Regional Economic Development, S. Goetz, S. Deller, and T. Harris (eds) New York: Routledge.

Delta Development Group Inc. and Gannet Fleming (2003) A Comprehensive Economic Analysis for Huntingdon County. Delta Development Group.

Goetz, S., Deller, S., Harris, T. (2009) Introduction and Overview. Targeting Regional Economic Development, S. Goetz, S. Deller, and T. Harris (eds) New York: Routledge.

Huntingdon County (2007) Update of Comprehensive Plan. Huntingdon County, Pennsylvania.

Huntingdon County (2003) Summary of Comprehensive Economic Analysis Summary Report. Huntingdon County, Pennsylvania.

Huntingdon County Business and Industry (2011) Top Ten County Industries for 2010. Huntingdon County Chamber of Commerce.

MIG, Inc., IMPLAN System. (2011) Pennsylvania 2009 Data. Hudson, WI . Online. Available. Http: www.implan.com

Porter, M. (2003) The Economic Performance of Regions. Regional Studies, 37 (6-7): 549-578.

Porter, M. (1998) Clusters and The New Economics of Competition. Harvard Business Review, 76 (6): 77-90. 
Romanelli, E. and Khessina, M. (2005) Regional Industrial Identity. Organization Science 16 (4): 344-358.

Scott, R. (2003) The high price of "free” trade. NAFTA's failure has cost the United States jobs across the nation. Economic Policy Institute.

Shaffer, W. (1999) Regional Impact Models in The Web Book of Regional Science, edited by Scott Loveridge. The Regional Research Institute, West Virginia University. Online. Available. Http://www.wvu.edu/ regional/regscweb

Shields, M., Barkley, D., and Emery, M. (2009) Industry Clusters and industry targeting. Targeting Regional Economic Development, S. Goetz, S. Deller, and T. Harris (eds) New York: Routledge.

Shields, M. (2002) Pennsylvania's Rural Economy: An Analysis of Recent Trends. College of Agricultural Sciences Agricultural Research and Cooperative Extension. Pennsylvania State University. State College, Pennsylvania

Shields, M. (2004) Using Employment Data to Better Understand Your Local Economy. College of Agricultural Sciences Agricultural and Cooperative Extension. Pennsylvania State University. State College, Pennsylvania.

Stonehouse, G. and Snowdon, B. (2007) Competitive Advantage Revisited: Michael Porter on Strategy and Competitiveness. Journal of Management Inquiry 16: 256-273.

U.S. Department of Commerce, Bureau of the Census (2010). Decennial Census Generated by Amanda Krugh. www.census.gov (files generated March 2011)

U.S. Department of Labor, Bureau of Labor Statistics (2011). Unemployment Statistics. Generated by Amanda Krugh. www.bls.gov (files generated March 2011)

Wisconsin Madison Extension. (2004) N.E.W. Economic Opportunity Study Subrgeional Report: 1-43 Corridor. University of Wisconsin, Madison Wisconsin. 


\section{Chapter 3.}

This chapter was completed in a style specified by the Community Development Journal.

\section{The Social Embeddedness of Rural Economic Restructuring: Impacts of Economic Change on Rural Households.}

\section{Introduction}

Economic restructuring linked to global outsourcing of labor and industrial decline have had major impacts on the lives of rural Americans. Transition away from resource-based economies to service-based economies has impacted many rural communities. Due to this economic restructuring, many rural areas today are dominated by low wage jobs, underemployment, and lack of employment opportunities (Slack 2007). Economic action in response to these economic changes is socially embedded and involves social relations, norms, gendered relations, power, and family dynamics. Social relations shape how local economic restructuring is perceived, experienced, and responded to by individuals and households. Locational context, or an individual's locality, is a major component of social embeddedness and is important to the understanding of how rural people are affected by economic change. The locational context of an area involves the historical economic roots, culture, and practices of a community that impact the employment and occupational opportunities, resources, and income levels of households. This paper uses the social embeddedness and locational context perspectives to better understand the meaning of economic restructuring in the lives of rural households. Interview data from a rural Pennsylvanian community affected by economic restructuring is analyzed using these perspectives to examine what economic and social adjustments and strategies are made in response to economic change. 
The second section discusses the locational context and social embeddedness concepts used within this paper. How economic change is experienced by households and individuals is influenced by the locational context which involves local historical economic structure, resource potential, and occupational opportunities. The social embeddedness perspective understands that economic and social actions are not mutually exclusive, economic relations have social content. Background information on the case study area, interview participants, and interview methodology is provided in the third section. The interviews conducted center on interpretation of local economic change and the cost of these changes on household and individual livelihoods. The fourth section of the paper explains the importance of locality to social relationships and economic decisions. This paper studies how the location context of employment options, resources, and labor market characteristics influence the response households make to economic change. Statements, opinions, and personal experiences shared by interview participants highlight how the participants perceive their local economic options, why many remain in the area regardless of economic opportunity, and how their rural location impacts their livelihoods. Discussion of community development and planning implications are provided.

The fifth section of the paper focuses on the perceptions, understanding, and response of the interviewees to economic change. Livelihood strategies are then discussed relating to formal and informal employment. The importance of social relationships for household economic strategies is examined. The emphasis of this work is on the social relations such as kinship, gendered roles, and community support that influence the aspects of making a living. In addition, policy implications and community 
development recommendations are discussed given the economic strategies of the interview participants. Finally, the conclusion summarizes the findings of this paper. The outcomes of the interviews and the significance of this research to both rural research and Huntingdon County are discussed.

\section{Locational Context and Social Embeddedness}

Locational context, or an individual's locality, is a major component of social embeddedness and is important to the understanding of how rural people are affected by economic change. Linda Lobao defines localities as "settings of social interaction, specific to time and place, where structures and institutions shape and are shaped by the activity of their inhabitants” (Lobao 1993 p 25). Locational context influences the economic options and decisions of households through the availability of economic opportunity, quality of life features, and social and historic ties that attract people to live there. For this paper locational context refers to the features of a particular place that affect the employment and quality of life of the households interviewed. These economic social relations are spatially defined, often at the local scale.

This paper also uses the social embeddedness perspective to analyze how social relations have influenced economic decisions of the households interviewed. This approach recognizes that economic action is constrained and facilitated by ongoing social relationships. No economic action is purely decided by maximum cost benefit, instead they involve social relations that influence action. Embeddedness, brought to the forefront of rural economic studies by Mark Granovetter’s 1985 work aims to explain how economic transactions become embedded in social relations that differentially affect and influence the distribution and value of resources (Granovetter 1985). By emphasizing 
the social embeddedness of economic action, researchers seek to end the idea of separate realms of understanding action as either economic or social. Instead, it should be recognized that economic and social actions are not mutually exclusive, economic relations have social content and social relations and dynamics have economic content. This understanding can be used to examine the social context of economic restructuring on household economic and social action. Tigges et al (1998 p 204) explains that "The restructuring of places both leads to and is defined by the restructuring of social relationships in places." This paper uses the embeddedness perspective to better understand how social relationships are involved in times of economic change and influence people's understanding of their situations and options.

\section{Case Study Area and Methods of Research} Huntingdon County

The case study area for this paper is Huntingdon County, within rural Central Pennsylvania (Figure 1). Household interviews were conducted in the rural localities of Huntingdon County within the communities of Mount Union, Shade Hill, and Orbisonia. Huntingdon County was selected because of its current economic situation. This rural county has experienced recent consistent high unemployment, job loss, low wages, and weak economic performance in relation to the state and nation due to economic restructuring in the last three decades. Similar to many rural areas in the nation, Huntingdon County's transition from a resource-based economy to a service-based economy has impacted the economic base of this region. 
Figure 1. Case Study Area

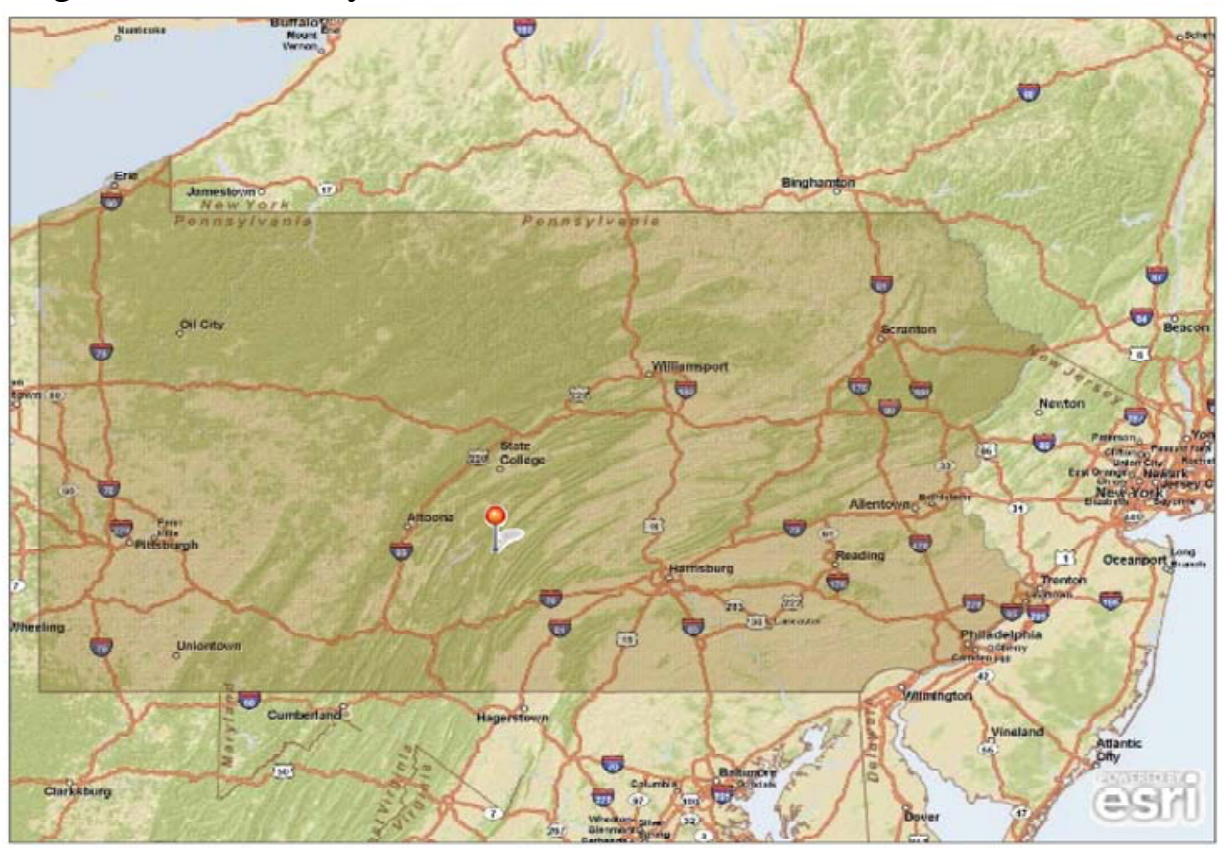

Interviews

For this research semi-structured interviews were conducted to allow for ordered but flexible questioning. This style allows the researcher to ask content focused questions but also permits new topics and questions to emerge (Bradshaw and Stratford 2005). The interviews were transcribed and analyzed using Nvivo Qualitative computer analysis to code the transcriptions and highlight patterns and relationships. Twenty two people were interviewed for this study. Six of the interviews involved two people of various relationships and the other ten household interviews were conducted on an individual basis. One of the criterions for selection to participate in this study was residence in the Huntingdon County. Purposive sampling was used with the intent to have a representative group of age, income, occupations and genders. Ages of the participants ranged from 22-80 with nine women and thirteen men. All but two of the participants currently lived within the community surrounding the Mount Union, Shade Hill, and Orbisonia area. All of the participants had at one time worked within the local workforce 
and were either currently employed, retired, and one was both in school and working. Of the thirteen men, ten were retired from or were currently employed in blue collar positions. All of the women had at sometime worked within the workforce and outside of the home. The majority of participants are considered low income. The table below provides an overview of the participant's age, occupation, income, education, and marital status. The names of the participants have been changed.

Figure 2 Participant Information

\begin{tabular}{|c|c|c|c|c|c|c|}
\hline$\frac{\text { Participant First }}{\text { Name - }}$ & Age Range & Income Range & Occupation & Relationship Status & Education & Retired \\
\hline Jack & $66-75$ & $\$ 19,000-\$ 25,000$ & Postal Service & Married & Some College & $Y$ \\
\hline Jen & $66-75$ & $\$ 19,000-\$ 25,000$ & $\begin{array}{l}\text { Sewing Factory, } \\
\text { School Attendant }\end{array}$ & Married & High School & $\mathrm{N}$ \\
\hline Bob & $76+$ & $\$ 10,000-\$ 19,000$ & Farmer & Married (widowed) & Some High School & $\mathrm{Y}$ \\
\hline Brad & $50-65$ & $\$ 10,000-\$ 19,000$ & Barber & Married & Technical School & $\mathrm{N}$ \\
\hline Chris & $66-75$ & $\$ 35,001-\$ 45,000$ & $\begin{array}{c}\text { Manufacturing } \\
\text { Contractor, Farmer }\end{array}$ & Married & $\begin{array}{c}\text { High School } \\
\text { Technical School }\end{array}$ & $\mathrm{N}$ \\
\hline Doug & $50-65$ & $\$ 10,000-\$ 19,000$ & Dairy Farmer & Divorced & Some College & $\mathrm{N}$ \\
\hline Greg & $76+$ & $\$ 19,000-25000$ & Barber & Married & $\begin{array}{c}\text { High School Formal } \\
\text { Job Training }\end{array}$ & \\
\hline Rob Jr & $18-25$ & $\$ 45,000-\$ 50,000$ & $\begin{array}{l}\text { Heavy Equipment } \\
\text { Operator }\end{array}$ & Single & High School & $\mathrm{N}$ \\
\hline Rob & $36-49$ & $\$ 10,000-\$ 19,000$ & Excavating & Married & High School & $\mathrm{N}$ \\
\hline Howard & $50-65$ & $\$ 80,000-\$ 10,0000$ & Lawyer & Divorced & Graduate Degree & $\mathrm{N}$ \\
\hline Justin & $50-65$ & $\$ 45,000-\$ 50,000$ & Farming, Trucking & Married & High School & $\mathrm{N}$ \\
\hline Helen & $18-25$ & $\underline{\$} 10,000-\$ 19,000$ & $\begin{array}{c}\text { Nursing Student, } \\
\text { Farming }\end{array}$ & Single & Some College & $\mathrm{N}$ \\
\hline Tammi & $18-25$ & $\$ 10,000-\$ 19,000$ & Student, Farming & Single & Some College & $\mathrm{N}$ \\
\hline Ann & $50-65$ & $\$ 50,000-\$ 60,000$ & Healtheare & Married & Graduate Degree & $\mathrm{N}$ \\
\hline Jason & $36-49$ & $\$ 19,000-\$ 25,000$ & $\begin{array}{l}\text { PennDot, farmer, } \\
\text { Butcher }\end{array}$ & Married & High School & $\mathrm{N}$ \\
\hline Mary & $36-49$ & $\$ 45,000-\$ 50,000$ & $\begin{array}{c}\text { Baybsit } \\
\text { Grandchildren }\end{array}$ & Married & Some College & $\mathrm{N}$ \\
\hline Christy & $76+$ & $\$ 19,000-\$ 25,000$ & Dairy Farmer & Widowed & Some College & $Y$ \\
\hline Barb & $66-75$ & $\$ 35,000-\$ 45,000$ & Hair dresser & Married & Technical School & $\mathrm{Y}$ \\
\hline Aaron & $66-75$ & $\$ 35,001-\$ 45,000$ & Newspaper Farmer & Married & College Degree & $\overline{\mathrm{N}}$ \\
\hline Frank & $36-49$ & $\$ 50,000-\$ 60,000$ & Planner & Married & College Degree & $Y$ \\
\hline Beth & $50-65$ & $\$ 80,000-\$ 10,0000$ & Healthcare & Marreid & College Degree & $\mathrm{Y}$ \\
\hline Amy & $76+$ & $\$ 110,000-\$ 19,000$ & Manufacturing & Widowed & Technical School & $\mathrm{N}$ \\
\hline
\end{tabular}

\section{Locational Context: Rootedness and Quality of Life}

While the case study area is a set spatial county boundary, the locality of the interview participants is not precisely defined. The case study was chosen because of the economic decline, limited population growth, and unemployment rates of the entire county and how it impacts household decisions. However in the interviews, participants regarded "home" as a more local setting then the county level. All of the participants 
were from rural towns and villages with similar demographics and economic situations within Huntingdon County.

\section{Rootedness}

This study includes the embeddedness of a household within the local community or area and examines the topics of rootedness, attachment, and perceived quality of life of the interview participants. One measure of social embeddedness and influence by locational context is being rooted to an area with physical or social ties that cause a household to remain in a specific place (Hanson and Pratt 1995). For this study I look at rootedness by households that obtained land or homes, or local businesses through connections with a family member. By inheriting land, property, or occupations, these participants were locally rooted. Nine of the interviewees were provided land or homes by family members. Eight of the participants were trained and inherited local family businesses or farms through social relationships. This rootedness influences the economic decisions of households in various ways. For one, the effect of inheriting housing is that housing costs are likely lower, requiring less income to purchase and maintain the household. Inheriting the family business or farm does provide employment however the occupation is often associated or tied to local need or resources so it may be limiting in income or growth possibilities. Another impact is that the household is now tied to the locality because of the physical location of the housing or business (Hanson and Pratt 1995).

Doug, a dairy farmer, was given the farm he currently operates from his mother and father. His mother and father were handed down the farm from their parents. Doug, and his mother Christy, explain how the farm was passed on from generation to generation. 
Doug: $\quad$ Dairy farming for 36 years. My mom and dad had it before me.

Christy: $\quad$ But, then my father decided to sell this farm - it was my father's farm. Well my father lived here - this was my grandmother's house. It goes back all those generations.

Doug: $\quad$ It certainly helped me get started - buying from mom and dad.

Doug and his mother show how the farm property, both a business and home, helped both families get started.

Quality of Life

A majority of the participants explained that quality of life, and family relations were important considerations in their decision to stay in the area regardless of the economic opportunities. Community attachment and satisfaction has been the topic of many rural studies. Huntingdon County's comprehensive plan states that $86 \%$ of residents surveyed considered their communities within the county very desirable citing family ties and the rural setting as reasons for living in the area (Huntingdon County 2007). Factors found to be related positively to community attachment include duration of local residence and home ownership (Theordori 2001). All of the participants had lived the majority of their lives in the same community. None of the participants rented their homes but instead owned or lived with family members who owned their homes. The characteristics are consistent with the wider community, in a Quality of Life Survey (QOL) conducted within the County as part of the Huntingdon County Comprehensive Plan in over $85 \%$ of survey respondents in the case study community had lived in the area over 20 years and 86\% owned their own homes (Huntingdon County 2007). According to the U.S. Census, Huntingdon County’s home ownership rates were at $77.3 \%$, over $10 \%$ higher than the homeownership rates for Pennsylvania or the nation (Census 2010). For both the QOL survey and participant interviews conducted for his project, attachment to 
the community and perceived quality of life were main reasons given for staying in the area. Howard, a lawyer in his 50's that owns his own practice, describes why he stayed regardless of the economic impact it may have had for his household.

Well it's like, you know, a lot of times I think that I could have probably done better financially had I not come back here. But, I liked the area and I'm not, I hope the kids aren't disappointed that I came back here, but, I'm not sure if the grass on the other side of the street is any greener and I'm not sure that I would even like the rat race.

Howard's prioritized the quality of life over income. To him, remaining in a rural area, one he grew up in, was more important than the job opportunities he may have had elsewhere. Overwhelmingly, the participants were very satisfied with their quality of life base on their locality. Family and historical ties were prominent in discussions on why they chose to stay in the area.

Classic economic understanding would expect individuals and households facing unemployment, low wages, and limited economic opportunity to move to areas with better economic conditions. However, social relationships play a vital role in housing decisions. Residential relocation is a complex decision frequently motivated more by social relations and quality of life decisions than a rational decision based on employment or perceived cost of living advantages. The decision on where to live is affected by history, relationships with family and friends, and lifestyle preferences, and not solely affected by economic cost and benefit analysis. Relocation has social costs that outweigh the economic cost for many households, and many people choose to remain in their locality despite poor economic conditions (Ziebarth and Tigges 2003). Of the twentytwo interview participants, $90 \%$ had chosen to stay in the area and have developed varied livelihood strategies in order to be able to financially survive. The following section focuses on these households and strategies which include long commutes, two family 
incomes, and self provisioning, actions that often require the help of social relations and family ties.

\section{Household Perception of and Response to Economic Change}

People's views on their local economy and the economic and social changes they have seen in their area over time provide some insight about how locality and social relations impact their economic decisions and livelihoods. In this section, I present the perceptions, knowledge, and understanding participants have on the past and present local economy.

Huntingdon County has a rich industrial history tied to the brick refractories industry, which was the economic backbone of this rural area for decades starting in the late $19^{\text {th }}$ century. Three companies produced silica brick products in the area. Regional production and employment within this industry peaked in the late 1940s. The three companies, following national and state industry economic trends, continuously declined until the late 1980s and early 1990s when the companies closed and the industry left the area (National Park Service 1990). The sewing factory was the one other additional industry mentioned numerous times regarding main employers of the past. The Greif Brothers, a suit manufacturer in Mount Union, and the Arrow Shirts factory in Huntingdon, known as simply as the sewing factories, were large employers of women within this area for decades (Keiser 1994, National Park Service 1990). The two factories were closed by the late 1980s. Justin, a truck driver in his 50's remembers the different industries from when he was growing up.

In 1965, we had 3 brickyards in Mount Union. We had a sewing factory in Mount Union. We had a shoe factory in Mount Union. Right now today, their all gone. Our little town was booming Friday and Saturday nights, you couldn’t walk down the sidewalk. 
Christy, a former dairy farmer in her late 80s, describes who was a main employer in the region when she was growing up in the 1920s.

There were a lot of people that worked at the brickyard. And I think it was the main business ....for a long time. That and the sewing factory.

Rob Jr., a 25 year old excavator, remembers the brickyards as a main industry as well.

Brickyards (were the main employer) I would say. There were three brickyards in Mount Union. I would say that was your main place of employment around here. They shut down his and then Harbison-Walker was right after that. That's why it is the way it is (the region). It used to be decent now it's terrible.

The importance of the brickyards and sewing factory to the economic identity of this community spans generations. Justin, Rob, and Christy are different ages and grew up at different times; however, they all identified the brickyards as the main employer. It is interesting to note that employment in the brickyard industries peaked in this area in the late 1940s with almost 1500 employees within Huntingdon County. Twenty years later the employment had declined to 600 employees and by 1980 the brickyards employed only 335 workers countywide. When the brickyards closed in the 1990s there were less than 75 workers county wide within this industry (National Park Service 1990). While the interview participant's perspective the local economy during their childhood may not be entirely accurate it reflects the significance of the brickyards to how the participant's identify with their community.

Overall, participants associated regional economic change with the decline of jobs, local population, services, employment and general economic and social health of the region. Rob Jr. and Chris talk about the limited employment in the area. Rob Jr., 25, is an excavator and due to lack of local job opportunities and lagging construction work in the area he travels away from the community five days a week for employment. Chris, 
in his 60s, was working at a production plant that closed last year due to outsourcing; he currently is working on his family farm.

Rob Jr.: $\quad$ It's hard to go to work - like if I was to get laid off - I'd make $\$ 600.00$ a week on unemployment ......sitting here doing nothing. It's hard for me to go to work for $\$ 10.00$ an hour and only make $\$ 400.00$ And you can't do that .You're losing money to work that's not ... That doesn't make sense. That's what the problem is here. Everyone had a good job - well now they are all gone all the good jobs are gone.

Chris: $\quad$ No quality jobs for quality people. There are jobs here but not a gross amount of them for people that don't want to put any extra effort - that's not saying it nicely, but that's fact. We need to entice manufacturing - manufacturing jobs is one of the best livelihoods that is consistent. If you get a manufacturing facility going, if you have got a good product, it just keeps, you know, sell the product, and you need raw material and so on.

Rob Jr. and Chris both emphasize that quality employment, with reasonable wages and stable employment have left the region. They also both associate these good jobs with the social structure of the community. Beth, in her 50s who lives outside the area now explains how the economic restructuring and changes impacted the local community's youth and the people living there.

Beth: Mount Union I think is just dying. Those brickyards closed down in the 70's, maybe early 80's,- young kids don't stay. I mean, I was a typical example, I moved away.......If we had two large factories come in, I think it would go back to its boom days.

Beth illustrates the perspective of many of the participants, that the economic restructuring in this area is directly connected with social decline in the community. The impacts are not simply "economic” but affect how the community identifies and feels about the locality they live in. As did a majority of the participants, Chris and Beth both identify that bringing manufacturing plants into the community will revitalize both the economy and social structure of the community. The social relationships and dynamics that the interview participants associate with their locality are embedded in the economics 
of the community, how they identify their community through the historical manufacturing roots, and how they see the social structure of the community impacted by economic decline. Social embeddedness influences how individuals understand and perceive change.

Community Development Planning Implications and Recommendations: Household Perceptions and Understanding of Economic Change

Community identity is vital to the development of both economic and social capital. Work is a major component of how a community defines itself. Community is the setting for social action and work is an integral part of what forms a community (Falk et al 2003). The majority of participants identify their community with the historical brickyard industry of the area, and the manufacturing work of that industry. Work is embedded in relationships and structures, and set in communities with their own histories geographies, and social relations. With an identity tied to manufacturing, participant perception of ideal job production and economic development focuses on bringing in similar manufacturing industries for work. The participant's opinions and sentiments are consistent with the overall region. The QOL Survey showed that when asked about job production and economic development, the county citizens identified attracting outside employers and industries with incentives such as tax breaks as the top way to create jobs (Huntingdon County 2007). A focus on manufacturing, although historically and culturally significant to the community, may not be the most productive or viable choice for economic development.

Manufacturing employment, once historical mainstays in rural communities, are especially vulnerable to outsourcing, low wages, and cyclical employment (Tickamyer and Duncan 1990). During the 1960s and 1970s, manufacturing and resource extraction 
brought some stability to rural regions but economic structural changes in the 1980s left many rural areas with higher unemployment, lower wages, and less opportunities than their urban counterparts (Slack 2010). Growing international competition for product markets and cheap labor during the 1980s affected rural areas in particular, especially those dependent on a few key industries (Lichter and McLaughlin 1995). Huntingdon County and the rural localities of the interview participants followed these rural economic trends. In 1990, the manufacturing sector in Huntingdon County employed nearly $25 \%$ of the county's workforce, but only within a few employers. As several of these manufacturing industries downsized and left the area, the unemployment rate in the region reached $13 \%$. Manufacturing, declining locally and nationally may prove to be a poor choice for economic focus in the region.

Director of Huntingdon County Planning and Development Department, Richard Stahl has a different perspective of economic development than many community members.

\footnotetext{
'we are at a disadvantage for attracting multi-national chains.... to support our large firms. It's sort of the luck of the draw, you know, and of course, they go as quickly as they can come... ...In this day and age with a lot of jobs being exported, mechanization can occur in foreign countries as well as here I think that there is a strong belief - and my personal belief, is that rural communities to really rely on entrepreneurial initiatives In rural communities, I think we are much better off developing local homegrown industries and helping those folks grow.' But there are people that continue to chase smoke stacks long after the smoke stacks are gone.
}

The social relationships and dynamics that the interview participants associate with their locality are embedded in the economic identity and work of the community. Planning and economic development agencies need to promote a different idea of economic development to the community, and inform citizens of other options such as small business incubators, technology development, and regional collaborations for economic 
development in order for communities to be invested in new ideas and perspectives outside their "manufacturing” identity.

\section{Household Economic and Livelihood Strategies: Commuting, Dual Income Households, and Informal Work.}

The embeddedness perspective contends that economic action is both controlled and facilitated by social relationships (Falk et al 2003, Granovetter 1985). Among those households that choose not to relocate, many have relied on strategies that are embedded in the local context and social relationships within the community to improve their financial situation. Some of the strategies used by the interview participants include commuting long distances; having dual income household; and engaging in informal work to supplement income. These strategies involve household economic decisions and actions that are heavily weighed by social considerations. Community development and planning implications of each livelihood strategy are discussed.

\section{Commuting as a Livelihood Strategy}

A common household strategy to minimize limited local employment opportunities and low wages is by commuting to other areas for work. The average commuting time for the study area municipalities is 33 minutes compared to the state average of 25 minutes to work (United States Department of Commerce 2010). There were several participants that had over an hour drive each way to work and three of the participants worked away from home during the week. Beth, a nurse, describes her daily commute.

50 miles each way. I work in Bedford. I would like to not have to travel so far.

Chris and Jen, a retired couple in their 60s, describe that travel is involved in most activates in addition to employment because of the limited resources in the area. 
Other than banks and grocery stores, you can't buy anything in Mt. Union anymore. I'm sure that's prevalent in most rural areas if you want to do any shopping to amount to anything you have to drive.

Similar to many rural areas, many goods and services are not readily available within the Mount Union area. Chris and Jen find that travel is required for most activities. While the strategy of commuting allows for individuals and households to avoid relocating for income or work purposes, it can have significant social and economic costs. Commuting long distances takes time away from family other social connections, physically and socially distances the commuter from the locality, and requires gas and car maintenance expenses.

Community Development and Planning Implications and Recommendations: Commuting as a Livelihood Strategy

The time spent commuting to work has become a major concern of policymakers and the public in recent years with increased attention to rural regions. As indicated with the responses of the interview participants, commuting has become an integral part of rural Pennsylvanian life. According to the QOL survey over 20\% of workers surveyed were employed outside of the County (Huntingdon County 2007). While many reasons can contribute to an area's high level of commuting, lack of local job opportunities is a primary cause. Commuting long distances for work has both economic and social implications for the individual such as uncompensated costs of fuel, vehicle maintenance, and auto insurance and increased time away from home and lack of community connectedness and diminished social capital of a community (Stomes and Brown 2002). Community impact of separation of work and residence may leave many rural areas with higher levels of residents, requiring services and facilities, but without access to the tax base of the employment center to fund or supply the needed services. 
As commuting as an economic strategy in rural areas continues, communities will need to adapt. Planning collaborations and adoption of concepts of economic development that center on a regional network of employment and housing options can aid communities (Sheilds et al 2009). Regional alliances can bolster local economies, help pool funds to maintain public services, and increase economic opportunities. The concept of regional economic development is not new, but application to struggling rural areas has been somewhat limited and development plans have focused on a singular sector or on certain segments of the population. In contrast, a regional approach focuses on pooling resources and develops a diverse range of economic opportunities.

\section{Dual Income Households as a Livelihood Strategy}

Another common household strategy to maximize income is to have dual incomes. The restructuring of employment relations in men's jobs is associated with women’s increasing labor participation (Haynie and Gorman 1999). In rural areas, women traditionally have had lower rates of labor force participation but a decrease in men’s earnings and employment has been changing this dynamic. Shifting job opportunities such as the loss of male-dominated industries of manufacturing and resource extraction and the increase of female dominated service jobs have impacted households and communities (Oberhauser 1995). Due to these factors, many households find themselves dependent on more than one income. Traditional gender roles and division of household labor are affected by this shift (Oberhauser 1995, Hanson and Pratt 1995).

Gender relations play a center role in the economic structure of rural communities and economic decisions of households. Jen discusses below the necessity for many 
families, due to job loss and unemployment, to have the woman work outside the home, a decision that went outside normal gender roles.

It used to be you thought of the man as sole provider but a lot of ladies had to work to keep their families going. That's why I went because we needed to - it wasn't that I wanted to.

Jen discusses the necessity for many families, due to job loss and unemployment, to have the woman work outside the home, a decision that went outside normal gender roles. She continued with the discussion on working and highlights the difficulty many women experience with their duel responsibilities as caregiver and income provider. The social relations and dynamic of women working outside the home are made clear by Jen and her husband Chris in the discussion below.

Jen: $\quad$ And it wasn't that I was against working, I just wanted to stay home with my baby. If she had been a little older it would have been different.

Chris: Necessity is the mother of invention.

Jen: I went in and applied. It was only a little bit till I was hired.

Chris: I drove her in and told her she was going to apply for a job and she cried then she got out of the car. She would never let me forget it.

Jen: $\quad$ She was just a little over year old. I can’t take credit for potty training her - Blanche and Jason did that because she was with them more than with me. I'd get her up in the morning and dress her and take her across the road. I wouldn't see her until late afternoon, then I'd feed her, bathe her, and put to bed. I felt I only saw on the weekends.

Jen recalls how her husband Chris insisted that she take the job even though she wanted to stay home with her children. While it is generally both members of a couple who adopt that family's gender strategy, various research suggest that it is typically the men whose ideologies ultimately direct it (Sherman 2009). Despite increases in women's labor force participation, traditional gender relations within the home often persist (Hanson and Pratt 1995). The social relations and responsibilities Jen felt for her children caused stress as she worked outside the home because of economic need. As described in Jen's interview the traditional gender roles, while changing, still center women as the traditional childcare provider. 
Community Development and Planning Implications and Recommendations: Dual Income as a Livelihood Strategy

Rural families are challenged by changes associated with the restructuring of the rural economy. Restructuring has increased the likelihood that married women will enter the labor market due to economic necessity. Job loss in male-dominated industries of manufacturing and resource extraction and an increase of female dominated low wage service jobs have resulted in many rural families reliant on two incomes (Hanson and Pratt 1995). This dynamic provides a structure that supports the continuation and growth of an economy dominated by low wage service sector jobs. The labor market seeks employees that accept lower wages. With more women needing to work, employers can count on a dependable workforce that will accept lower wages as long their labor is required to support their families. Despite increasing labor force participation, traditional gender roles continue and rural mothers are increasingly asked to balance the demands of the labor market and their responsibility for much of the household work. (Struthers and Bokemier 2003).

Huntingdon County needs to focus on bringing quality positions to the region. Economic changes such as outsourcing, mechanization, and foreign competition, have rapidly transformed the Pennsylvania rural economy from one centered on the manufacturing sector to a dependence on the service industries. The service sector has replaced manufacturing in the case study area as the top employer. To assist dual family incomes and increase woman's standing in regard to income and power within the labor market economy, development initiatives should focus on increasing the quality of positions with the service sector. Specifically, for the case study area, investment and 
development in the health service industry is recommended. Statewide the health service industry is expected to have significant growth as an aging population requires increased levels of care (Huntingdon County 2007). Investment and development to retain and attract health care services would benefit Huntingdon County greatly. Huntingdon County’s health services, centered with the JC Blair Memorial Hospital are within close proximity to other regional healthcare facilities such as Altoona and State College (Huntingdon County 2007). The county can utilize these resources to enhance the area's rural health care services.

\section{Informal Work as a Livelihood Strategy}

Households are often motivated by social and economic necessity to generate additional income or find ways of self provisioning. The decisions of how to expand income or control expenses reflect the availability of resources and social connections. Paid work in many rural areas is not limited to formal employment and many use informal work to supplement their household income (Jensen et al 1995). Informal work can be compensated in many different ways making it difficult to categorize and define what constitutes the informal economy (Slack 2007). For the purpose of this study, in order to examine the presence of informal work within individual and household livelihood strategies, informal work is defined beyond activities that solely generate revenue to include unregulated work that provide payment in terms of cash or in-kind, bartering, and self-provisions (Edgcomb and Thetford 2004). Social relations are central to the facilitation of informal work. Social connections are utilized to find work opportunities and to maintain relations and trust necessary for bartering, or in-kind reciprocity. 
Current research indicates that the informal economy in rural areas has a larger presence and is more fundamental to the local economy than previously realized (Slack 2007). The informal economy is not unique to rural areas however there are a variety of reasons that the informal activities are an important component of the livelihood strategies of many rural households. Rural workers earn lower wages, have less formal employment opportunities, and less services and resources available than their urban counterparts (Slack 2010). In this study, Bob describes his struggles as a dairy farmer and how he used side work in order to pay his mortgage before he retired a couple years ago.

When the end of the month came and everything was divided, it wasn't hardly a living. I had other ways of making money. I sold things off the farm. That's how I paid (for my farm) mostly. The price of dairying was give and take. When I was done at the end of the month, I had hardly made a living. That's the way farming is now. I had other ways of making money. I sold things off the farm and turned it back onto the farm.

Bob describes how his economic situation was often unstable. He was able to supplement his income by selling produce and timber from the farm.

For others social and family obligations are the primary source of informal work. This is especially the case for work associated with women such as babysitting or healthcare. While men's informal work is often equated with market values and can be compensated, women's work is often naturalized and encouraged to be exchanges for like services rather than monetary payment. While these agreements are key to providing services that may be unaffordable or unavailable in the area such as childcare or healthcare, the market value and worth of this "women's work" is slighted (Nelson and Smith 1998). Three of the women I interviewed babysat as either a familial or social obligation. Mary explains how often she babysits for her grandchildren.

I will be watching them for part-time for two and the other two I watch - one is in school and the other is in pre-school three days a week. 
Mary's family relationships are the reasons for watching her grandchildren, as her daughter works full time. This social obligation is assumed to fall on Mary, because she is a woman and childcare is naturalized and assumed to be women's work. Mary's work as a babysitter is embedded in the social relationship she has with her daughter and it is also embedded in the gender roles of her family. While informal work takes various forms it constitutes an important part of rural living. For this study, $45 \%$ of participants had some involvement in the informal economy. The experiences of these individuals provide some insight into how informal work is used by rural residents to supplement income, assist family, or save money as part of their livelihood strategy. The experiences also highlight the important role of social relationships used to facilitate informal work.

\section{Community Development and Planning Implications and Recommendations: Informal} Work as a Livelihood Strategy

People engage in informal work for a variety of reasons. For some it is an economic necessity and others are involved for personal fulfillment, social obligation, or as a means to supplement the primary income (Tickamyer and Woods 2003). The interview participants engaged in informal work to supplement their primary job and to meet the needs of family for childcare. Communities face a challenge when addressing the informal economy. Since informal work is outside the regulatory control of the local government it can be seen as a threat to the environmental, safety, and labor standards of the region (Aspen Institute 2003). However in rural regions the informal economy provides households with extra income or services such as childcare that may be otherwise unaffordable or inaccessible. 
Development initiatives to encourage micro-entrepreneurship and formalize some side businesses may be a feasible strategy for job creation in communities that have lost jobs and economic opportunities due to economic restructuring. The key to this type of initiative is to identify informal workers that are appropriate targets for microentrepreneurship assistance (Slack 2007). Within the informal economy there are a range of participant types, these include informal workers that sell their labor either regularly or erratically; informal entrepreneurs who see their enterprise as a sideline business used to provide additional household income or meets a familial obligation; and informal entrepreneurs who strive to grow their enterprise or are considering it (Aspen Institute 2003). The latter group is the most eligible group to target with programs aimed to encourage micro-entrepreneurship. These programs should aim to assist microentrepreneurs to overcome barriers to legitimize their small businesses through technical assistance, low interest loans, and grant application assistance.

\section{Conclusion}

This paper examines the variety of perspectives and strategies utilized by rural households in a community affected by economic restructuring. The focus of this study is the ways in which social relationships and local economic context are embedded in the rural household decision-making in response to economic change (Ziebarth and Tigges 2003). Economic and social actions are not mutually exclusive, economic relations have social content (Falk et al 2003). The importance of social relationships for job training, informal work and bartering, and rootedness strategies used by households to "make a living” are made apparent throughout the interviews. The location context of employment options, resources, and labor market characteristics also are critical to the 
responses households make to economic change (Lobao 1993). In particular, the majority of the interviewees commuted considerable distances for employment; some held multiple low-paying jobs to make ends meet due to the constraints of employment opportunities and industrial structure of the case study area.

This research provides a snapshot of the ways in which rural households construct their lives and earn a living in the context of economic restructuring. Beyond the Huntingdon County households interviewed for this study, this case illustrates how the economic decisions, perceptions, and response of rural households to restructuring are embedded in social relations. Understanding of the social relation and local context of household economic action is valuable to rural studies (Falk et al 2003). With many rural households implementing one or more strategies to make ends meet such as commuting, two incomes, multiple jobs it is clear that if the economy in these areas continues to decline that these individual will be stretched beyond their limits (Sherman 2009). This study also provides discussion of community development and planning implications and recommendations for these communities as they plan for economic change. Planners, businesses, or community development authorities can utilize the information on the affect of limited local employment opportunities and rural household strategies to help promote job growth within the community and provide resources to assist these households. 


\section{Work Cited:}

Aspen Institute (2003). The Informal Economy and Microenterprise in the United States. Field Forum. 14: pp 1-6

Bokemeier, J. (1997) Rediscovering Families and Households: Restructuring Rural Society and Rural Sociology. Rural Sociology 62: pp 1-20

Bradshaw, M and Stratford, E. (2005) Qualitative Research Design and Rigor. Iain Hay (eds) Qualitative Research Methods in Human Geography. Second Addition. Oxford University Press. pp 37-49.

Dunn, K. (2005) Doing Qualitative Research in Human Geography. Iain Hay (eds).Qualitative Research Methods in Human Geography. Second Addition. Oxford University Press. pp 50-81.

Edgcomb, E. and Thetford, T. (2004) The Informal Economy: Making It In Rural America. Washington D.C: The Field Institute.

Falk, W, Schulman, M, and Tickamyer, A. (2003). Communities of Work: Rural Restructuring in Local and Global Contexts. Athens, OH: Ohio University Press.

Granovetter, M. (1985) Economic Action and Social Structure: the Problem of Embeddedness. American Journal of Sociology. 91: pp 481-93

Jensen, L., Cornwell, G. T. and Findeis, J. L. (1995) Informal Work in Nonmetropolitan Pennsylvania. Rural Sociology. 60: pp 91-107

Huntingdon County (2003) Summary of Comprehensive Economic Analysis Summary Report.Huntingdon County, Pennsylvania.

Huntingdon County (2007) Update of Comprehensive Plan. Huntingdon County, Pennsylvania.

Hanson, S. and Pratt, G. (1995) Gender, Work, and Space. New York: Routledge.

Haynie, D. and Gorman, B. (1999) A Gendered Context of Opportunity: Determinants of Poverty Across Urban and Rural Labor Markets. The Sociological Quarterly. 40: pp 177197.

Kieser, J. (1994) The Mount Union Manufacturing Company. Huntingdon County Historical Society.

Lichter, D. and McLaughlin, D. (1995) Changing Linkages between work and Poverty in Rural America. Rural Sociology. 59: pp 395-415. 
Lobao, L. (1993) The Renewed Significance of Space in Social Research: Implications for Labor Market Studies. In Inequalities in Labor Market Areas. Edited by Joachim Singelmann and Forrest Deseran. Boulder, CO: Westview Press. pp 11-31.

McLaughlin, D. (2002) Changing Income Inequality in Nonmetropolitan Counties, 19802000. Rural Sociology. 67: pp 512-513.

National Park Service. (1990) Historic American Buildings Survey Refractories Company Towns HABS No. PA-5547. U.S. Department of the Interior. Washington D.C.

Nelson, M. and Smith, J. (1998). Working Hard and Making Do. Surviving in Small town America. Berkley, CA. University of California Press.

Oberhauser, A. (1995).Towards a Gendered Regional Geography: Women and Work in Rural Appalachia. Growth and Change. 26: pp 219-246.

Scott, R. (2003) The high price of "free” trade. NAFTA's failure has cost the United States jobs across the nation. Economic Policy Institute.

Sherman, J. (2009). Bend to Avoid Breaking: Job Loss, Gender Norms, and Family Stability in Rural America. Social Problems. 56: pp 599-620.

Shields, M., Barkley, D., and Emery, M. (2009) Industry Clusters and Industry Targeting. Targeting Regional Economic Development, S. Goetz, S. Deller, and T. Harris (eds) New York: Routledge.

Slack, T. (2007) The Contours and Correlates of Informal Work in Rural Pennsylvania. Rural Sociology. 72: pp 69-89.

Slack, T. (2010). Working Poverty across the Metro-Nonmetro Divide: A Quarter-Century in Perspective, 1979-2003. Rural Sociology. 75: pp 362-386.

Slack, Tim. (2007) Work, Welfare, and the Informal Economy: Toward an Understanding of Household Livelihood Strategies. Community Development. 38: pp 2642.

Slack T. and Jensen L. (2002) Race, Ethnicity, and Underemployment in Nonmetropolitan America: A 30 year Profile. Rural Sociology. 67: pp 208-233.

Stomes, E. and Brown, D. (2002) Transportation in rural America: Issues for the $21^{\text {st }}$ Century. Rural America. 16: pp1-10

Struthers, C. and Bokemeier, J. (2003). Stretched to Their Limits: Rural Nonfarm Mothers and the "New" Rural Economy. Communities of Work: Rural Restructuring in Local and Global Contexts, Falk, W, Schulman, M, and Tickamyer, A (eds) Ohio: Center for International Studies. pp 291-315. 
Theodori, G. (2001) Examining the Effects of Community Satisfaction and Attachment on Individual Well-Being. Rural Sociology. 66 pp 618-628.

Tickamyer, A. and Wood, T. (2003).The Social and Economic Context of Informal Work. Communities of Work: Rural Restructuring in Local and Global Contexts, Falk, W; Schulman, M; and Tickamyer, A (eds) Ohio: Center for International Studies. pp 394415

Tickamyer, A. and Duncan, C. (1990) Poverty and Opportunity Structure in Rural America. Annual Review of Sociology. 16 pp 67-86.

Tigges, L., Ziebarth, A., and Farnham, J. (1998) Social Relationships in Locality and Livelihood: The Embeddedness of Rural Economic Restructuring. Journal of Rural Studies. 14 pp 203-219.

United States Department of Commerce, Bureau of the Census (2010). Decennial Census Generated by Amanda Krugh. www.census.gov (files generated March 2011).

Ziebarth, A. and Tigges, L. (2003) Earning a Living and Building a Life: IncomeGenerating and Income-Saving Strategies of Rural Wisconsin Families. Communities of Work: Rural Restructuring in Local and Global Contexts, Falk, W; Schulman, M; and Tickamyer, A (eds) Ohio: Center for International Studies. pp 315-338 
Location Quotient and Basic Sector

\begin{tabular}{|c|c|c|c|c|}
\hline Description & $\begin{array}{l}\text { Employment } \\
\text { Huntingdon } \\
\text { County } 2009\end{array}$ & $\begin{array}{c}\text { Employment } \\
\text { National } \\
2009\end{array}$ & $\begin{array}{l}\text { Location } \\
\text { Quotient }\end{array}$ & $\begin{array}{l}\text { Basic Sector } \\
\text { Employment }\end{array}$ \\
\hline Total & 17360 & 172400746 & & \\
\hline Ag, Forestry, Fish \& Hunting & 915 & 3385667 & 2.68 & 574 \\
\hline 111 Crop Farming & 206 & 1633893 & 1.25 & 41 \\
\hline 112 Livestock & 635 & 935055 & 6.75 & 541 \\
\hline 113 Forestry \& Logging & 27 & 123292 & 2.21 & 15 \\
\hline 114 Fishing- Hunting \& Trapping & 7 & 97928 & 0.70 & -3 \\
\hline 115 Ag \& Forestry Svcs & 40 & 595498 & 0.67 & -20 \\
\hline Mining & 99 & 1056578 & 0.93 & -8 \\
\hline 211 Oil \& gas extraction & 8 & 477091 & 0.16 & -40 \\
\hline 213 Mining services & 0 & 318571 & 0.00 & -32 \\
\hline Utilities & 71 & 575680 & 1.22 & 13 \\
\hline 221 Utilities & 71 & 575680 & 1.22 & 13 \\
\hline Construction & 1222 & 9872194 & 1.23 & 228 \\
\hline 230 Construction & 1222 & 9872194 & 1.23 & 228 \\
\hline Manufacturing & 1988 & 12037058 & 1.64 & 776 \\
\hline 311 Food products & 46 & 1476784 & 0.31 & -103 \\
\hline 312 Beverage \& Tobacco & 14 & 195657 & 0.73 & -5 \\
\hline 313 Textile Mills & 18 & 254035 & 0.69 & -8 \\
\hline 314 Textile Products & 0 & 203817 & 0.00 & -21 \\
\hline 316 Leather \& Allied & 0 & 31213 & 0.00 & -3 \\
\hline 321 Wood Products & 240 & 398183 & 5.98 & 200 \\
\hline 322 Paper Manufacturing & 566 & 396122 & 14.19 & 526 \\
\hline 323 Printing \& Related & 54 & 562877 & 0.95 & -3 \\
\hline 324 Petroleum \& coal prod & 0 & 113187 & 0.00 & -11 \\
\hline 325 Chemical Manufacturing & 22 & 793976 & 0.27 & -58 \\
\hline 326 Plastics \& rubber prod & 277 & 631618 & 4.35 & 213 \\
\hline 327 Nonmetal mineral prod & 88 & 395057 & 2.21 & 48 \\
\hline 331 Primary metal mfg & 0 & 362218 & 0.00 & -36 \\
\hline 332 Fabricated metal prod & 32 & 1316697 & 0.24 & -101 \\
\hline 333 Machinery Mfg & 0 & 1027592 & 0.00 & -103 \\
\hline 334 Computer \& oth electron & 505 & 1090243 & 4.60 & 396 \\
\hline 335 Electircal eqpt \& appliances & 54 & 370390 & 1.44 & 16 \\
\hline 336 Transportation eqpmt & 0 & 1333063 & 0.00 & -134 \\
\hline 337 Furniture \& related prod & 51 & 402426 & 1.25 & 10 \\
\hline 339 Miscellaneous mfg & 23 & 681904 & 0.33 & -46 \\
\hline Wholesale Trade & 301 & 5889220 & 0.51 & -292 \\
\hline 42 Wholesale Trade & 301 & 5889220 & 0.51 & -292 \\
\hline Retail trade & 1675 & 17684816 & 0.94 & -106 \\
\hline 441 Motor veh \& parts dealers & 170 & 1841545 & 0.92 & -15 \\
\hline 442 Furniture \& home furnishings & 12 & 519262 & 0.23 & -40 \\
\hline
\end{tabular}




\begin{tabular}{|c|c|c|c|c|}
\hline $\begin{array}{l}443 \text { Electronics \& appliances } \\
\text { stores }\end{array}$ & 22 & 526664 & 0.42 & -31 \\
\hline $\begin{array}{l}\text { 444 Bldg materials \& garden } \\
\text { dealers }\end{array}$ & 119 & 1222563 & 0.97 & -4 \\
\hline 445 food \& beverage stores & 403 & 2952521 & 1.36 & 106 \\
\hline 446 Health \& personal care stores & 131 & 1165033 & 1.12 & 14 \\
\hline 447 Gasoline stations & 156 & 853428 & 1.82 & 70 \\
\hline 448 Clothing \& accessories stores & 20 & 1561153 & 0.13 & -137 \\
\hline $\begin{array}{l}451 \text { Sports- hobby- book \& music } \\
\text { stores }\end{array}$ & 41 & 777133 & 0.52 & -37 \\
\hline 452 General merch stores & 334 & 2988235 & 1.11 & 33 \\
\hline 453 Misc retailers & 167 & 1576367 & 1.05 & 8 \\
\hline 454 Non-store retailers & 99 & 1700913 & 0.58 & -72 \\
\hline Transportation \& Warehousing & 472 & 5551418 & 0.84 & -87 \\
\hline 481 Air transportation & 3 & 470437 & 0.06 & -44 \\
\hline 482 Rail Transportation & 8 & 179037 & 0.46 & -10 \\
\hline 483 Water transportation & 0 & 72022 & 0.00 & -7 \\
\hline 484 Truck transportation & 288 & 1979490 & 1.44 & 88 \\
\hline 485 Transit \& ground passengers & 117 & 672326 & 1.73 & 49 \\
\hline 486 Pipeline transportation & 2 & 40771 & 0.45 & -2 \\
\hline 487 Sightseeing transportation & 8 & 651933 & 0.12 & -58 \\
\hline 492 Couriers \& messengers & 1 & 807132 & 0.01 & -80 \\
\hline 493 Warehousing \& storage & 46 & 678271 & 0.67 & -22 \\
\hline Information & 145 & 3359208 & 0.43 & -194 \\
\hline 511 Publishing industries & 67 & 904928 & 0.74 & -24 \\
\hline $\begin{array}{l}512 \text { Motion picture \& sound } \\
\text { recording }\end{array}$ & 13 & 431674 & 0.31 & -30 \\
\hline 515 Broadcasting & 31 & 1439051 & 0.22 & -114 \\
\hline 518 Internet $\&$ data process svcs & 33 & 583555 & 0.56 & -26 \\
\hline $\begin{array}{l}\text { Real estate \& rental, Finance } \\
\text { and insurance }\end{array}$ & 633 & 16612060 & 0.38 & -1040 \\
\hline 521 Monetary authorities & 208 & 1889110 & 1.09 & 17 \\
\hline 522 Credit inmediation \& related & 9 & 903255 & 0.10 & -82 \\
\hline 523 Securities \& other financial & 12 & 2554750 & 0.05 & -245 \\
\hline 524 Insurance carriers \& related & 290 & 2765497 & 1.04 & 11 \\
\hline 525 Funds- trusts $\&$ other finan & 0 & 403123 & 0.00 & -41 \\
\hline 531 Real estate & 71 & 7298913 & 0.10 & -664 \\
\hline 532 Rental \& leasing svcs & 44 & 736648 & 0.59 & -31 \\
\hline $\begin{array}{l}533 \text { Lessor of nonfinance intang } \\
\text { assets }\end{array}$ & 0 & 60764 & 0.00 & -6 \\
\hline Service Sector & 6073 & 71420654 & 0.84 & -1119 \\
\hline $\begin{array}{l}541 \text { Professional- scientific \& tech } \\
\text { svcs }\end{array}$ & 347 & 12123904 & 0.28 & -874 \\
\hline 551 Management of companies & 41 & 1873182 & 0.22 & -147 \\
\hline
\end{tabular}




\begin{tabular}{|l|c|c|c|c|}
\hline 561 Admin support svcs & 182 & 9477591 & 0.19 & -772 \\
\hline $\begin{array}{l}562 \text { Waste mgmt \& remediation } \\
\text { svcs }\end{array}$ & 44 & 376699 & 1.17 & 6 \\
\hline 611 Educational svcs & 646 & 3640961 & 1.76 & 279 \\
\hline 621 Ambulatory health care & 526 & 7087680 & 0.74 & -187 \\
\hline 622 Hospitals & 430 & 4526887 & 0.94 & -26 \\
\hline 623 Nursing \& residential care & 549 & 3121963 & 1.75 & 235 \\
\hline 624 Social assistance & 535 & 3686211 & 1.44 & 164 \\
\hline $\begin{array}{l}\text { 711 Performing arts \& spectator } \\
\text { sports }\end{array}$ & 41 & 1655565 & 0.24 & -126 \\
\hline 712 Museums \& similar & 15 & 111627 & 1.37 & 4 \\
\hline $\begin{array}{l}713 \text { Amusement- gambling \& } \\
\text { recreation }\end{array}$ & 159 & 1874372 & 0.84 & -29 \\
\hline 721 Accomodations & 176 & 1344773 & 1.30 & 40 \\
\hline 722 Food svcs \& drinking places & 930 & 10428660 & 0.89 & -120 \\
\hline 811 Repair \& maintenance & 263 & 2327653 & 1.12 & 29 \\
\hline 812 Personal \& laundry svcs & 184 & 2189909 & 0.84 & -36 \\
\hline $\begin{array}{l}\text { 813 Religious- grantmaking- \& } \\
\text { similar orgs }\end{array}$ & 650 & 3142664 & 2.05 & 334 \\
\hline 814 Private households & 352 & 2430353 & 1.44 & 107 \\
\hline Government \& non NAICs & $\mathbf{3 7 6 6}$ & $\mathbf{2 4 9 5 6 1 9 2}$ & $\mathbf{1 . 5 0}$ & $\mathbf{1 2 5 3}$ \\
\hline 92 Government \& non NAICs & 3766 & 24956192 & 1.50 & 1253 \\
\hline Total & 17360 & 172400746 & & \\
\hline
\end{tabular}


National Growth Share

\begin{tabular}{|c|c|c|c|}
\hline Aggregated Sector & \begin{tabular}{|c|} 
Huntingdon \\
County \\
Employment \\
2001 \\
\end{tabular} & \begin{tabular}{|c|} 
National \\
Employment \\
Growth Rate
\end{tabular} & $\begin{array}{c}\text { National } \\
\text { Growth } \\
\text { Share by } \\
\text { Industry }\end{array}$ \\
\hline Total & 17845 & 0.02 & 386.8 \\
\hline Ag, Forestry, Fish \& Hunting & 1152 & 0.02 & 24.97 \\
\hline 111 Crop Farming & 336 & 0.02 & 7.3 \\
\hline 112 Livestock & 736 & 0.02 & 16.0 \\
\hline 113 Forestry \& Logging & 67 & 0.02 & 1.5 \\
\hline 114 Fishing- Hunting \& Trapping & 0 & 0.02 & 0.0 \\
\hline 115 Ag \& Forestry Svcs & 12 & 0.02 & 0.3 \\
\hline Mining & 24 & 0.02 & 0.53 \\
\hline 211 Oil \& gas extraction & 0 & 0.02 & 0.0 \\
\hline 212 Mining & 23 & 0.02 & 0.5 \\
\hline 213 Mining services & 1 & 0.02 & 0.0 \\
\hline Utilities & 101 & 0.02 & 2.19 \\
\hline 221 Utilities & 101 & 0.02 & 2.2 \\
\hline Construction & 1337 & 0.02 & 28.98 \\
\hline 230 Construction & 1337 & 0.02 & 29.0 \\
\hline Manufacturing & 2385 & 0.02 & 51.70 \\
\hline 311 Food products & 9 & 0.02 & 0.2 \\
\hline 312 Beverage \& Tobacco & 0 & 0.02 & 0.0 \\
\hline 313 Textile Mills & 0 & 0.02 & 0.0 \\
\hline 314 Textile Products & 92 & 0.02 & 2.0 \\
\hline 316 Leather \& Allied & 2 & 0.02 & 0.0 \\
\hline 321 Wood Products & 220 & 0.02 & 4.8 \\
\hline 322 Paper Manufacturing & 286 & 0.02 & 6.2 \\
\hline 323 Printing \& Related & 49 & 0.02 & 1.1 \\
\hline 324 Petroleum \& coal prod & 52 & 0.02 & 1.1 \\
\hline 325 Chemical Manufacturing & 0 & 0.02 & 0.0 \\
\hline 326 Plastics \& rubber prod & 223 & 0.02 & 4.8 \\
\hline 327 Nonmetal mineral prod & 514 & 0.02 & 11.1 \\
\hline 331 Primary metal mfg & 0 & 0.02 & 0.0 \\
\hline 332 Fabricated metal prod & 361 & 0.02 & 7.8 \\
\hline 333 Machinery Mfg & 0 & 0.02 & 0.0 \\
\hline 334 Computer \& oth electron & 568 & 0.02 & 12.3 \\
\hline 335 Electircal eqpt \& appliances & 0 & 0.02 & 0.0 \\
\hline 336 Transportation eqpmt & 0 & 0.02 & 0.0 \\
\hline 337 Furniture \& related prod & 5 & 0.02 & 0.1 \\
\hline 339 Miscellaneous mfg & 5 & 0.02 & 0.1 \\
\hline Wholesale Trade & 339 & 0.02 & 7.34 \\
\hline 42 Wholesale Trade & 339 & 0.02 & 7.3 \\
\hline Retail trade & 1984 & 0.02 & 43.00 \\
\hline 441 Motor veh \& parts dealers & 268 & 0.02 & 5.8 \\
\hline 442 Furniture \& home furnishings & 16 & 0.02 & 0.4 \\
\hline $\begin{array}{l}443 \text { Electronics \& appliances } \\
\text { stores }\end{array}$ & 18 & 0.02 & 0.4 \\
\hline $\begin{array}{l}\text { 444 Bldg materials \& garden } \\
\text { dealers }\end{array}$ & 168 & 0.02 & 3.6 \\
\hline 445 food \& beverage stores & 530 & 0.02 & 11.5 \\
\hline 446 Health \& personal care stores & 124 & 0.02 & 2.7 \\
\hline
\end{tabular}




\begin{tabular}{|c|c|c|c|}
\hline 447 Gasoline stations & 208 & 0.02 & 4.5 \\
\hline 448 Clothing \& accessories stores & 18 & 0.02 & 0.4 \\
\hline $\begin{array}{l}451 \text { Sports- hobby- book \& music } \\
\text { stores }\end{array}$ & 52 & 0.02 & 1.1 \\
\hline 452 General merch stores & 122 & 0.02 & 2.6 \\
\hline 453 Misc retailers & 205 & 0.02 & 4.5 \\
\hline 454 Non-store retailers & 252 & 0.02 & 5.5 \\
\hline Transportation \& Warehousing & 399 & 0.02 & 8.65 \\
\hline 481 Air transportation & 0 & 0.02 & 0.0 \\
\hline 482 Rail Transportation & 0 & 0.02 & 0.0 \\
\hline 483 Water transportation & 0 & 0.02 & 0.0 \\
\hline 484 Truck transportation & 161 & 0.02 & 3.5 \\
\hline 485 Transit \& ground passengers & 220 & 0.02 & 4.8 \\
\hline 486 Pipeline transportation & 1 & 0.02 & 0.0 \\
\hline 487 Sightseeing transportation & 9 & 0.02 & 0.2 \\
\hline 492 Couriers \& messengers & 0 & 0.02 & 0.0 \\
\hline 493 Warehousing \& storage & 8 & 0.02 & 0.2 \\
\hline Information & 166 & 0.02 & 3.60 \\
\hline 511 Publishing industries & 75 & 0.02 & 1.6 \\
\hline $\begin{array}{l}512 \text { Motion picture \& sound } \\
\text { recording }\end{array}$ & 13 & 0.02 & 0.3 \\
\hline 515 Broadcasting & 70 & 0.02 & 1.5 \\
\hline 518 Internet $\&$ data process svcs & 8 & 0.02 & 0.2 \\
\hline $\begin{array}{l}\text { Real estate \& rental, Finance } \\
\text { and insurance }\end{array}$ & 934 & 0.02 & 20.24 \\
\hline 521 Monetary authorities & 304 & 0.02 & 6.6 \\
\hline 522 Credit inmediation \& related & 6 & 0.02 & 0.1 \\
\hline 523 Securities \& other financial & 23 & 0.02 & 0.5 \\
\hline 524 Insurance carriers \& related & 289 & 0.02 & 6.3 \\
\hline 525 Funds- trusts \& other finan & 0 & 0.02 & 0.0 \\
\hline 531 Real estate & 106 & 0.02 & 2.3 \\
\hline 532 Rental \& leasing svcs & 205 & 0.02 & 4.4 \\
\hline $\begin{array}{l}\text { 533 Lessor of nonfinance intang } \\
\text { assets }\end{array}$ & 0 & 0.02 & 0.0 \\
\hline Service Sector & 6043 & 0.02 & 131.00 \\
\hline $\begin{array}{l}541 \text { Professional- scientific \& tech } \\
\text { svcs }\end{array}$ & 427 & 0.02 & 9.3 \\
\hline 551 Management of companies & 0 & 0.02 & 0.0 \\
\hline 561 Admin support svcs & 360 & 0.02 & 7.8 \\
\hline $\begin{array}{l}562 \text { Waste mgmt \& remediation } \\
\text { svcs }\end{array}$ & 53 & 0.02 & 1.2 \\
\hline 611 Educational svcs & 1499 & 0.02 & 32.5 \\
\hline 621 Ambulatory health care & 206 & 0.02 & 4.5 \\
\hline 622 Hospitals & 240 & 0.02 & 5.2 \\
\hline 623 Nursing \& residential care & 335 & 0.02 & 7.3 \\
\hline 624 Social assistance & 104 & 0.02 & 2.3 \\
\hline $\begin{array}{l}711 \text { Performing arts \& spectator } \\
\text { sports }\end{array}$ & 39 & 0.02 & 0.8 \\
\hline 712 Museums \& similar & 4 & 0.02 & 0.1 \\
\hline
\end{tabular}




\begin{tabular}{|l|c|c|c|}
\hline $\begin{array}{l}\text { 713 Amusement- gambling \& } \\
\text { recreation }\end{array}$ & 153 & 0.02 & 3.3 \\
\hline 721 Accomodations & 160 & 0.02 & 3.5 \\
\hline 722 Food svcs \& drinking places & 992 & 0.02 & 21.5 \\
\hline 811 Repair \& maintenance & 558 & 0.02 & 12.1 \\
\hline 812 Personal \& laundry svcs & 186 & 0.02 & 4.0 \\
\hline $\begin{array}{l}\text { 813 Religious- grantmaking- \& } \\
\text { similar orgs }\end{array}$ & 590 & 0.02 & 12.8 \\
\hline 814 Private households & 137 & 0.02 & 3.0 \\
\hline Government \& non NAICs & $\mathbf{2 9 8 1}$ & $\mathbf{0 . 0 2}$ & $\mathbf{6 4 . 6 1}$ \\
\hline 92 Government \& non NAICs & 2981 & 0.02 & 64.6 \\
\hline Total & 17845 & 0.02 & 386.8 \\
\hline
\end{tabular}


Industry Mix Share

\begin{tabular}{|c|c|c|c|c|}
\hline Description & $\begin{array}{c}\text { National } \\
\text { Growth Rate } \\
\text { by Industry }\end{array}$ & \begin{tabular}{|c|} 
National \\
Growth Rate \\
all \\
Industries
\end{tabular} & \begin{tabular}{|l|} 
Employment \\
Huntingdon \\
County 2001
\end{tabular} & $\begin{array}{c}\text { Industry } \\
\text { Mix } \\
\text { Huntingdon } \\
\text { County }\end{array}$ \\
\hline Total & 0.02 & 0.02 & 17845 & 0.0 \\
\hline Ag, Forestry, Fish \& Hunting & -0.13 & 0.02 & 1152 & -175.81 \\
\hline 111 Crop Farming & -0.06 & 0.02 & 336 & -27.1 \\
\hline 112 Livestock & -0.27 & 0.02 & 736 & -213.9 \\
\hline 113 Forestry \& Logging & -0.13 & 0.02 & 67 & -10.5 \\
\hline 114 Fishing- Hunting \& Trapping & -0.17 & 0.02 & 0 & 0.0 \\
\hline 115 Ag \& Forestry Svcs & -0.04 & 0.02 & 12 & -0.8 \\
\hline Mining & 0.37 & 0.02 & 24 & 8.62 \\
\hline 211 Oil \& gas extraction & 0.50 & 0.02 & 0 & 0.0 \\
\hline 212 Mining & 0.07 & 0.02 & 23 & 1.2 \\
\hline 213 Mining services & 0.53 & 0.02 & 1 & 0.6 \\
\hline Utilities & -0.01 & 0.02 & 101 & -3.28 \\
\hline 221 Utilities & -0.01 & 0.02 & 101 & -3.3 \\
\hline Construction & -0.10 & 0.02 & 1337 & -161.49 \\
\hline 230 Construction & -0.10 & 0.02 & 1337 & -161.5 \\
\hline Manufacturing & -0.27 & 0.02 & 2385 & -705.17 \\
\hline 311 Food products & -0.10 & 0.02 & 9 & -1.0 \\
\hline 312 Beverage \& Tobacco & -0.05 & 0.02 & 0 & 0.0 \\
\hline 313 Textile Mills & -0.22 & 0.02 & 0 & 0.0 \\
\hline 314 Textile Products & -0.68 & 0.02 & 92 & -65.1 \\
\hline 316 Leather \& Allied & -0.48 & 0.02 & 2 & -1.0 \\
\hline 321 Wood Products & -0.35 & 0.02 & 220 & -82.8 \\
\hline 322 Paper Manufacturing & -0.30 & 0.02 & 286 & -92.9 \\
\hline 323 Printing \& Related & -0.30 & 0.02 & 49 & -15.8 \\
\hline 324 Petroleum \& coal prod & -0.06 & 0.02 & 52 & -4.2 \\
\hline 325 Chemical Manufacturing & -0.14 & 0.02 & 0 & 0.0 \\
\hline 326 Plastics \& rubber prod & -0.30 & 0.02 & 223 & -72.7 \\
\hline 327 Nonmetal mineral prod & -0.27 & 0.02 & 514 & -149.2 \\
\hline 331 Primary metal mfg & -0.36 & 0.02 & 0 & 0.0 \\
\hline 332 Fabricated metal prod & -0.21 & 0.02 & 361 & -84.5 \\
\hline 333 Machinery Mfg & -0.24 & 0.02 & 0 & 0.0 \\
\hline 334 Computer \& oth electron & -0.36 & 0.02 & 568 & -218.2 \\
\hline 335 Electircal eqpt \& appliances & -0.32 & 0.02 & 0 & 0.0 \\
\hline 336 Transportation eqpmt & -0.30 & 0.02 & 0 & 0.0 \\
\hline 337 Furniture $\&$ related prod & -0.42 & 0.02 & 5 & -2.4 \\
\hline 339 Miscellaneous mfg & -0.12 & 0.02 & 5 & -0.7 \\
\hline Wholesale Trade & -0.04 & 0.02 & 339 & -19.56 \\
\hline 42 Wholesale Trade & -0.04 & 0.02 & 339 & -19.6 \\
\hline Retail trade & -0.03 & 0.02 & 1984 & -112.17 \\
\hline 441 Motor veh \& parts dealers & -0.10 & 0.02 & 268 & -32.8 \\
\hline 442 Furniture \& home furnishings & -0.16 & 0.02 & 16 & -3.0 \\
\hline $\begin{array}{l}443 \text { Electronics \& appliances } \\
\text { stores }\end{array}$ & -0.14 & 0.02 & 18 & -3.0 \\
\hline $\begin{array}{l}444 \text { Bldg materials \& garden } \\
\text { dealers }\end{array}$ & 0.00 & 0.02 & 168 & -4.4 \\
\hline 445 food \& beverage stores & -0.06 & 0.02 & 530 & -42.6 \\
\hline
\end{tabular}




\begin{tabular}{|c|c|c|c|c|}
\hline 446 Health \& personal care stores & 0.06 & 0.02 & 124 & 4.8 \\
\hline 447 Gasoline stations & -0.13 & 0.02 & 208 & -30.9 \\
\hline 448 Clothing \& accessories stores & 0.06 & 0.02 & 18 & 0.8 \\
\hline $\begin{array}{l}451 \text { Sports- hobby- book \& music } \\
\text { stores }\end{array}$ & -0.12 & 0.02 & 52 & -7.3 \\
\hline 452 General merch stores & 0.03 & 0.02 & 122 & 0.9 \\
\hline 453 Misc retailers & 0.01 & 0.02 & 205 & -1.4 \\
\hline 454 Non-store retailers & -0.05 & 0.02 & 252 & -19.2 \\
\hline Transportation \& Warehousing & -0.11 & 0.02 & 399 & -51.60 \\
\hline 481 Air transportation & -0.25 & 0.02 & 0 & 0.0 \\
\hline 482 Rail Transportation & 0.00 & 0.02 & 0 & 0.0 \\
\hline 483 Water transportation & 0.23 & 0.02 & 0 & 0.0 \\
\hline 484 Truck transportation & 0.22 & 0.02 & 161 & 31.9 \\
\hline 485 Transit \& ground passengers & -0.21 & 0.02 & 220 & -52.0 \\
\hline 486 Pipeline transportation & -0.08 & 0.02 & 1 & -0.1 \\
\hline 487 Sightseeing transportation & 0.07 & 0.02 & 9 & 0.4 \\
\hline 492 Couriers \& messengers & 0.02 & 0.02 & 0 & 0.0 \\
\hline 493 Warehousing \& storage & 0.20 & 0.02 & 8 & 1.4 \\
\hline Information & -0.14 & 0.02 & 166 & -26.14 \\
\hline 511 Publishing industries & -0.18 & 0.02 & 75 & -15.4 \\
\hline $\begin{array}{l}512 \text { Motion picture \& sound } \\
\text { recording }\end{array}$ & 0.03 & 0.02 & 13 & 0.1 \\
\hline 515 Broadcasting & -0.20 & 0.02 & 70 & -15.6 \\
\hline 518 Internet \& data process svcs & 0.05 & 0.02 & 8 & 0.2 \\
\hline $\begin{array}{l}\text { Real estate \& rental, Finance } \\
\text { and insurance }\end{array}$ & 0.22 & 0.02 & 934 & 185.82 \\
\hline 521 Monetary authorities & 0.07 & 0.02 & 304 & 14.1 \\
\hline 522 Credit inmediation \& related & 0.07 & 0.02 & 6 & 0.3 \\
\hline 523 Securities \& other financial & 0.10 & 0.02 & 23 & 1.9 \\
\hline 524 Insurance carriers \& related & 0.04 & 0.02 & 289 & 6.6 \\
\hline 525 Funds- trusts \& other finan & 0.41 & 0.02 & 0 & 0.0 \\
\hline 531 Real estate & 0.59 & 0.02 & 106 & 60.2 \\
\hline 532 Rental \& leasing svcs & -0.34 & 0.02 & 205 & -75.1 \\
\hline $\begin{array}{l}533 \text { Lessor of nonfinance intang } \\
\text { assets }\end{array}$ & 0.92 & 0.02 & 0 & 0.0 \\
\hline Service Sector & 0.10 & 0.02 & 6043 & 468.13 \\
\hline $\begin{array}{l}541 \text { Professional- scientific \& tech } \\
\text { svcs }\end{array}$ & 0.10 & 0.02 & 427 & 32.8 \\
\hline 551 Management of companies & 0.07 & 0.02 & 0 & 0.0 \\
\hline 561 Admin support svcs & 0.03 & 0.02 & 360 & 2.2 \\
\hline $\begin{array}{l}562 \text { Waste mgmt \& remediation } \\
\text { svcs }\end{array}$ & 0.12 & 0.02 & 53 & 5.1 \\
\hline 611 Educational svcs & 0.37 & 0.02 & 1499 & 515.4 \\
\hline 621 Ambulatory health care & 0.29 & 0.02 & 206 & 54.4 \\
\hline 622 Hospitals & 0.10 & 0.02 & 240 & 19.7 \\
\hline 623 Nursing \& residential care & 0.11 & 0.02 & 335 & 29.7 \\
\hline 624 Social assistance & 0.36 & 0.02 & 104 & 35.3 \\
\hline
\end{tabular}




\begin{tabular}{|l|c|c|c|c|}
\hline $\begin{array}{l}711 \text { Performing arts \& spectator } \\
\text { sports }\end{array}$ & 0.08 & 0.02 & 39 & 2.3 \\
\hline 712 Museums \& similar & 0.12 & 0.02 & 4 & 0.3 \\
\hline $\begin{array}{l}\text { 713 Amusement- gambling \& } \\
\text { recreation }\end{array}$ & 0.14 & 0.02 & 153 & 18.7 \\
\hline 721 Accomodations & -0.04 & 0.02 & 160 & -9.2 \\
\hline 722 Food svcs \& drinking places & 0.03 & 0.02 & 992 & 10.2 \\
\hline 811 Repair \& maintenance & -0.34 & 0.02 & 558 & -201.5 \\
\hline 812 Personal \& laundry svcs & 0.11 & 0.02 & 186 & 16.9 \\
\hline $\begin{array}{l}\text { 813 Religious- grantmaking- \& } \\
\text { similar orgs }\end{array}$ & 0.14 & 0.02 & 590 & 69.8 \\
\hline 814 Private households & 0.34 & 0.02 & 137 & 43.3 \\
\hline Government \& non NAICs & $\mathbf{0 . 0 9}$ & $\mathbf{0 . 0 2}$ & $\mathbf{2 9 8 1}$ & $\mathbf{2 1 3 . 0 6}$ \\
\hline 92 Government \& non NAICs & 0.05 & 0.02 & 2981 & 93.5 \\
\hline Total & 0.02 & 0.02 & 17845 & 0.0 \\
\hline
\end{tabular}


Local Share

\begin{tabular}{|c|c|c|c|c|}
\hline Description & $\begin{array}{c}\text { Huntingdon } \\
\text { County } \\
\text { Growth Rate }\end{array}$ & $\begin{array}{c}\text { National } \\
\text { Growth Rate } \\
\end{array}$ & $\begin{array}{l}\text { Employment } \\
\text { Huntingdon } \\
\text { County } 2001 \\
\text { by Industry } \\
\end{array}$ & \begin{tabular}{|c} 
Competitive \\
Advantage \\
by \\
Huntingdon \\
Couny \\
Industry \\
\end{tabular} \\
\hline Total & & 0.02 & 17845 & -386.8 \\
\hline Ag, Forestry, Fish \& Hunting & -0.21 & -0.13 & 1152 & -86.04 \\
\hline 111 Crop Farming & -0.39 & -0.06 & 336 & -110.6 \\
\hline 112 Livestock & -0.14 & -0.27 & 736 & 96.8 \\
\hline 113 Forestry \& Logging & -0.59 & -0.13 & 67 & -30.9 \\
\hline 114 Fishing- Hunting \& Trapping & 0.00 & -0.17 & 0 & 0.0 \\
\hline 115 Ag \& Forestry Svcs & 2.23 & -0.04 & 12 & 28.2 \\
\hline Mining & $\mathbf{0 . 0 0}$ & 0.50 & 24 & -12.23 \\
\hline 211 Oil \& gas extraction & 3.03 & 0.37 & 0 & 0.0 \\
\hline 212 Mining & 2.88 & 0.07 & 23 & 65.7 \\
\hline 213 Mining services & -1.00 & 0.53 & 1 & -1.7 \\
\hline Utilities & -0.30 & -0.01 & 101 & -29.05 \\
\hline 221 Utilities & -0.30 & -0.01 & 101 & -29.1 \\
\hline Construction & -0.09 & -0.10 & 1337 & 17.27 \\
\hline 230 Construction & -0.09 & -0.10 & 1337 & 17.3 \\
\hline Manufacturing & -0.17 & -0.27 & 2385 & 256.59 \\
\hline 311 Food products & 4.36 & -0.10 & 9 & 37.9 \\
\hline 312 Beverage \& Tobacco & 0.00 & -0.05 & 0 & 0.0 \\
\hline 313 Textile Mills & 0.00 & -0.22 & 0 & 0.0 \\
\hline 314 Textile Products & -1.00 & -0.68 & 92 & -29.1 \\
\hline 316 Leather \& Allied & -1.00 & -0.48 & 2 & -1.0 \\
\hline 321 Wood Products & 0.09 & -0.35 & 220 & 98.2 \\
\hline 322 Paper Manufacturing & 0.98 & -0.30 & 286 & 366.2 \\
\hline 323 Printing \& Related & 0.11 & -0.30 & 49 & 20.1 \\
\hline 324 Petroleum \& coal prod & -1.00 & -0.06 & 52 & -48.7 \\
\hline 325 Chemical Manufacturing & 0.00 & -0.14 & 0 & 0.0 \\
\hline 326 Plastics \& rubber prod & 0.24 & -0.30 & 223 & 121.5 \\
\hline 327 Nonmetal mineral prod & -0.83 & -0.27 & 514 & -288.2 \\
\hline 331 Primary metal mfg & 0.00 & -0.36 & 0 & 0.0 \\
\hline 332 Fabricated metal prod & -0.91 & -0.21 & 361 & -252.2 \\
\hline 333 Machinery Mfg & 0.00 & -0.24 & 0 & 0.0 \\
\hline 334 Computer \& oth electron & -0.11 & -0.36 & 568 & 143.7 \\
\hline 335 Electircal eqpt \& appliances & 0.00 & -0.32 & 0 & 0.0 \\
\hline 336 Transportation eqpmt & 0.00 & -0.30 & 0 & 0.0 \\
\hline 337 Furniture \& related prod & 8.27 & -0.42 & 5 & 47.5 \\
\hline 339 Miscellaneous mfg & 3.69 & -0.12 & 5 & 18.7 \\
\hline Wholesale Trade & -0.11 & -0.04 & 339 & -24.96 \\
\hline 42 Wholesale Trade & -0.11 & -0.04 & 339 & -25.0 \\
\hline Retail trade & -0.16 & -0.03 & 1984 & -239.69 \\
\hline 441 Motor veh \& parts dealers & -0.36 & -0.10 & 268 & -70.7 \\
\hline 442 Furniture \& home furnishings & -0.27 & -0.16 & 16 & -1.8 \\
\hline $\begin{array}{l}443 \text { Electronics \& appliances } \\
\text { stores }\end{array}$ & 0.22 & -0.14 & 18 & 6.8 \\
\hline
\end{tabular}




\begin{tabular}{|c|c|c|c|c|}
\hline $\begin{array}{l}444 \text { Bldg materials \& garden } \\
\text { dealers }\end{array}$ & -0.29 & 0.00 & 168 & -48.4 \\
\hline 445 food \& beverage stores & -0.24 & -0.06 & 530 & -95.7 \\
\hline 446 Health \& personal care stores & 0.05 & 0.06 & 124 & -0.9 \\
\hline 447 Gasoline stations & -0.25 & -0.13 & 208 & -25.7 \\
\hline 448 Clothing \& accessories stores & 0.08 & 0.06 & 18 & 0.3 \\
\hline $\begin{array}{l}451 \text { Sports- hobby- book \& music } \\
\text { stores }\end{array}$ & -0.22 & -0.12 & 52 & -5.3 \\
\hline 452 General merch stores & 1.74 & 0.03 & 122 & 208.6 \\
\hline 453 Misc retailers & -0.19 & 0.01 & 205 & -41.4 \\
\hline 454 Non-store retailers & -0.61 & -0.05 & 252 & -139.6 \\
\hline Transportation \& Warehousing & 0.18 & -0.11 & 399 & 116.21 \\
\hline 481 Air transportation & 0.00 & -0.25 & 0 & 0.0 \\
\hline 482 Rail Transportation & 0.00 & 0.00 & 0 & 0.0 \\
\hline 483 Water transportation & 0.00 & 0.23 & 0 & 0.0 \\
\hline 484 Truck transportation & 0.78 & 0.22 & 161 & 90.8 \\
\hline 485 Transit \& ground passengers & -0.47 & -0.21 & 220 & -56.2 \\
\hline 486 Pipeline transportation & 0.86 & -0.08 & 1 & 0.9 \\
\hline 487 Sightseeing transportation & -0.12 & 0.07 & 9 & -1.7 \\
\hline 492 Couriers \& messengers & 0.00 & 0.02 & 0 & 0.0 \\
\hline 493 Warehousing \& storage & 4.96 & 0.20 & 8 & 36.8 \\
\hline Information & -0.13 & -0.14 & 166 & 1.06 \\
\hline 511 Publishing industries & -0.10 & -0.18 & 75 & 6.6 \\
\hline $\begin{array}{l}512 \text { Motion picture \& sound } \\
\text { recording }\end{array}$ & 0.03 & 0.03 & 13 & -0.1 \\
\hline 515 Broadcasting & -0.55 & -0.20 & 70 & -24.8 \\
\hline 518 Internet \& data process svcs & 2.90 & 0.05 & 8 & 23.9 \\
\hline $\begin{array}{l}\text { Real estate \& rental, Finance } \\
\text { and insurance }\end{array}$ & -0.32 & 0.22 & 934 & -507.17 \\
\hline 521 Monetary authorities & -0.32 & 0.07 & 304 & -117.3 \\
\hline 522 Credit inmediation \& related & 0.61 & 0.07 & 6 & 3.1 \\
\hline 523 Securities \& other financial & -0.48 & 0.10 & 23 & -13.7 \\
\hline 524 Insurance carriers \& related & 0.00 & 0.04 & 289 & -12.2 \\
\hline 525 Funds- trusts \& other finan & 0.00 & 0.41 & 0 & 0.0 \\
\hline 531 Real estate & -0.34 & 0.59 & 106 & -98.2 \\
\hline 532 Rental \& leasing svcs & -0.79 & -0.34 & 205 & -91.1 \\
\hline $\begin{array}{l}\text { 533 Lessor of nonfinance intang } \\
\text { assets }\end{array}$ & 0.00 & 0.92 & 0 & 0.0 \\
\hline Service Sector & $\mathbf{0 . 0 0}$ & $\mathbf{0 . 1 0}$ & 6043 & -569.87 \\
\hline $\begin{array}{l}541 \text { Professional- scientific \& tech } \\
\text { svcs }\end{array}$ & -0.19 & 0.10 & 427 & -121.6 \\
\hline 551 Management of companies & 0.00 & 0.07 & 0 & 0.0 \\
\hline 561 Admin support svcs & -0.49 & 0.03 & 360 & -188.0 \\
\hline $\begin{array}{l}562 \text { Waste mgmt \& remediation } \\
\text { svcs }\end{array}$ & -0.17 & 0.12 & 53 & -15.3 \\
\hline 611 Educational svcs & -0.57 & 0.37 & 1499 & -1400.9 \\
\hline 621 Ambulatory health care & 1.55 & 0.29 & 206 & 261.4 \\
\hline
\end{tabular}




\begin{tabular}{|l|c|c|c|c|}
\hline 622 Hospitals & 0.79 & 0.10 & 240 & 165.2 \\
\hline 623 Nursing \& residential care & 0.64 & 0.11 & 335 & 177.7 \\
\hline 624 Social assistance & 4.14 & 0.36 & 104 & 393.6 \\
\hline $\begin{array}{l}\text { 711 Performing arts \& spectator } \\
\text { sports }\end{array}$ & 0.04 & 0.08 & 39 & -1.4 \\
\hline 712 Museums \& similar & 3.34 & 0.12 & 4 & 11.5 \\
\hline $\begin{array}{l}\text { 713 Amusement- gambling \& } \\
\text { recreation }\end{array}$ & 0.04 & 0.14 & 153 & -15.6 \\
\hline 721 Accomodations & 0.10 & -0.04 & 160 & 21.3 \\
\hline 722 Food svcs \& drinking places & -0.06 & 0.03 & 992 & -94.2 \\
\hline 811 Repair \& maintenance & -0.53 & -0.34 & 558 & -105.7 \\
\hline 812 Personal \& laundry svcs & -0.01 & 0.11 & 186 & -23.2 \\
\hline $\begin{array}{l}\text { 813 Religious- grantmaking- \& } \\
\text { similar orgs }\end{array}$ & 0.10 & 0.14 & 590 & -22.3 \\
\hline 814 Private households & 1.58 & 0.34 & 137 & 169.2 \\
\hline Government \& non NAICs & $\mathbf{0 . 2 6}$ & $\mathbf{0 . 0 9}$ & $\mathbf{2 9 8 1}$ & $\mathbf{5 0 7 . 8 0}$ \\
\hline 92 Government \& non NAICs & 0.26 & 0.05 & 2981 & 627.4 \\
\hline Total & & 0.02 & 17845 & -386.8 \\
\hline
\end{tabular}




\begin{tabular}{|c|c|c|c|c|}
\hline & Wage and Salary Per Job & & & \\
\hline & Description & Huntingdon (\$) & State (\$) & National \\
\hline 1 & Transport by pipeline & $94,572.89$ & $111,014.35$ & $119,322.39$ \\
\hline 2 & $\begin{array}{l}\text { All other chemical product and } \\
\text { preparation manufacturing }\end{array}$ & $94,278.23$ & $77,260.60$ & $78,463.98$ \\
\hline 3 & $\begin{array}{l}\text { Electric power generation, transmission, } \\
\text { and distribution }\end{array}$ & $92,364.31$ & $135,476.23$ & $118,630.95$ \\
\hline 4 & Transport by rail & $84,729.28$ & $84,817.08$ & $99,832.52$ \\
\hline 5 & $\begin{array}{l}\text { Management of companies and } \\
\text { enterprises }\end{array}$ & $70,496.60$ & $119,453.36$ & $110,368.86$ \\
\hline 6 & $\begin{array}{l}\text { All other miscellaneous professional, } \\
\text { scientific, and technical services }\end{array}$ & $68,106.73$ & $46,112.77$ & $42,823.07$ \\
\hline 7 & $\begin{array}{l}\text { All other miscellaneous electrical } \\
\text { equipment and component manufacturing }\end{array}$ & $66,667.05$ & $65,936.71$ & $76,996.66$ \\
\hline 8 & Natural gas distribution & $65,763.46$ & $100,160.73$ & $117,195.24$ \\
\hline 9 & $\begin{array}{l}\text { Mining and quarrying sand, gravel, clay, } \\
\text { and ceramic and refractory minerals }\end{array}$ & $63,501.96$ & $37,814.06$ & $47,905.04$ \\
\hline 10 & Mineral wool manufacturing & $61,953.72$ & $76,182.92$ & $73,222.86$ \\
\hline 11 & US Postal Service & $61,320.96$ & $82,893.13$ & $81,898.03$ \\
\hline 12 & Office administrative services & $60,939.90$ & $64,969.59$ & $61,639.77$ \\
\hline 13 & Telecommunications & $60,313.21$ & $80,472.18$ & $78,157.28$ \\
\hline 14 & Soft drink and ice manufacturing & $59,987.92$ & $63,648.68$ & $61,240.32$ \\
\hline 15 & Electronic connector manufacturing & $58,163.39$ & $65,637.95$ & $65,003.05$ \\
\hline 16 & Insurance carriers & $57,638.36$ & $71,911.41$ & $72,733.73$ \\
\hline 17 & $\begin{array}{l}\text { Office furniture and custom architectural } \\
\text { woodwork and millwork manufacturing }\end{array}$ & $57,162.21$ & $49,625.97$ & $57,207.21$ \\
\hline 18 & $\begin{array}{l}\text { Other state and local government } \\
\text { enterprises }\end{array}$ & $56,926.44$ & $65,654.56$ & $74,140.92$ \\
\hline 19 & $\begin{array}{l}\text { * Employment and payroll only (federal } \\
\text { govt, non-military) }\end{array}$ & $55,471.03$ & $106,474.56$ & $112,607.59$ \\
\hline 20 & $\begin{array}{l}\text { Other pressed and blown glass and } \\
\text { glassware manufacturing }\end{array}$ & $52,972.75$ & $54,963.16$ & $63,072.11$ \\
\hline 21 & $\begin{array}{l}\begin{array}{l}\text { Insurance agencies, brokerages, and } \\
\text { related activities }\end{array} \\
\end{array}$ & $52,909.76$ & $65,230.58$ & $61,241.31$ \\
\hline 22 & $\begin{array}{l}\text { Nondepository credit intermediation and } \\
\text { related activities }\end{array}$ & $51,824.97$ & $82,281.52$ & $78,934.43$ \\
\hline 23 & $\begin{array}{l}\text { State and local government passenger } \\
\text { transit }\end{array}$ & $50,330.34$ & $59,204.41$ & $65,331.38$ \\
\hline 24 & Private hospitals & $49,875.38$ & $61,058.44$ & $65,632.58$ \\
\hline 25 & Other animal food manufacturing & $48,942.07$ & $56,914.28$ & $55,583.01$ \\
\hline 26 & $\begin{array}{l}\text { * Employment and payroll only (state \& } \\
\text { local govt, education) }\end{array}$ & $47,013.15$ & $53,856.63$ & $55,624.40$ \\
\hline 27 & $\begin{array}{l}\text { * Employment and payroll only (state \& } \\
\text { local govt, non-education) }\end{array}$ & $45,870.42$ & $51,762.08$ & $58,102.33$ \\
\hline 28 & Mining coal & $45,839.31$ & $53,579.15$ & $71,983.13$ \\
\hline 29 & Wholesale trade businesses & $45,628.78$ & $69,927.61$ & $68,219.75$ \\
\hline 30 & $\begin{array}{l}\text { * Employment and payroll only (federal } \\
\text { govt, military) }\end{array}$ & $44,723.49$ & $55,936.96$ & $84,036.00$ \\
\hline 31 & $\begin{array}{l}\text { Waste management and remediation } \\
\text { services }\end{array}$ & $43,313.92$ & $53,481.44$ & $56,220.31$ \\
\hline 32 & Stationery product manufacturing & $43,165.47$ & $50,979.65$ & $57,027.70$ \\
\hline
\end{tabular}




\begin{tabular}{|c|c|c|c|c|}
\hline 33 & Custom computer programming services & $42,868.14$ & $66,119.25$ & $68,243.77$ \\
\hline 34 & $\begin{array}{l}\text { Private junior colleges, colleges, } \\
\text { universities, and professional schools }\end{array}$ & $41,976.46$ & $48,406.08$ & $43,398.63$ \\
\hline 35 & $\begin{array}{l}\text { Grantmaking, giving, and social } \\
\text { advocacy organizations }\end{array}$ & $41,303.70$ & $54,084.24$ & $46,985.28$ \\
\hline 36 & $\begin{array}{l}\text { Offices of physicians, dentists, and other } \\
\text { health practitioners }\end{array}$ & $41,141.97$ & $65,892.14$ & $63,836.46$ \\
\hline 37 & Other concrete product manufacturing & $40,760.18$ & $54,542.07$ & $53,293.81$ \\
\hline 38 & Ready-mix concrete manufacturing & $40,469.01$ & $52,180.68$ & $56,228.06$ \\
\hline 39 & Poultry and egg production & $39,214.66$ & $36,094.21$ & $26,727.02$ \\
\hline 40 & Mining and quarrying stone & $38,941.25$ & $38,961.86$ & $46,410.77$ \\
\hline 41 & Home health care services & $38,446.33$ & $36,360.31$ & $28,684.42$ \\
\hline 42 & $\begin{array}{l}\text { Animal (except poultry) slaughtering, } \\
\text { rendering, and processing }\end{array}$ & $37,453.69$ & $46,652.25$ & $44,034.93$ \\
\hline 43 & Other plastics product manufacturing & $36,848.86$ & $50,039.57$ & $52,413.79$ \\
\hline 44 & $\begin{array}{l}\text { Management, scientific, and technical } \\
\text { consulting services }\end{array}$ & $36,704.57$ & $63,738.18$ & $62,433.85$ \\
\hline 45 & Machine shops & $36,247.63$ & $54,586.08$ & $55,579.33$ \\
\hline 46 & Warehousing and storage & $36,050.62$ & $46,570.48$ & $45,778.79$ \\
\hline 47 & Curtain and linen mills & $34,498.85$ & $32,924.48$ & $39,174.16$ \\
\hline 48 & $\begin{array}{l}\text { Other amusement and recreation } \\
\text { industries }\end{array}$ & $34,137.50$ & $22,391.76$ & $24,648.87$ \\
\hline 49 & $\begin{array}{l}\text { Medical and diagnostic labs and } \\
\text { outpatient and other ambulatory care } \\
\text { services }\end{array}$ & $34,078.52$ & $46,378.94$ & $48,643.93$ \\
\hline 50 & $\begin{array}{l}\begin{array}{l}\text { Monetary authorities and depository } \\
\text { credit intermediation activities }\end{array} \\
\end{array}$ & $33,493.43$ & $59,949.10$ & $62,889.36$ \\
\hline 51 & \begin{tabular}{|l} 
Nonupholstered wood household \\
furniture manufacturing
\end{tabular} & $33,486.79$ & $35,157.27$ & $38,538.52$ \\
\hline 52 & $\begin{array}{l}\text { Travel arrangement and reservation } \\
\text { services }\end{array}$ & $33,470.05$ & $34,622.25$ & $37,153.66$ \\
\hline 53 & $\begin{array}{l}\text { Electronic and precision equipment } \\
\text { repair and maintenance }\end{array}$ & $33,213.07$ & $42,838.14$ & $42,053.46$ \\
\hline 54 & Sign manufacturing & $32,537.18$ & $50,801.10$ & $48,400.45$ \\
\hline 55 & Total & $32,101.40$ & $44,724.35$ & $45,319.64$ \\
\hline 56 & Other accommodations & $32,007.20$ & $40,248.05$ & $34,575.12$ \\
\hline 57 & $\begin{array}{l}\text { Environmental and other technical } \\
\text { consulting services }\end{array}$ & $31,518.99$ & $58,306.13$ & $53,669.01$ \\
\hline 58 & \begin{tabular}{|l}
$\begin{array}{l}\text { Architectural, engineering, and related } \\
\text { services }\end{array}$ \\
\end{tabular} & $31,295.67$ & $55,987.79$ & $57,435.48$ \\
\hline 59 & $\begin{array}{l}\text { Turned product and screw, nut, and bolt } \\
\text { manufacturing }\end{array}$ & $30,739.59$ & $61,968.72$ & $59,253.79$ \\
\hline 60 & Radio and television broadcasting & $30,661.87$ & $62,678.66$ & $71,555.45$ \\
\hline 61 & Dental laboratories manufacturing & $29,636.20$ & $42,804.84$ & $43,704.25$ \\
\hline 62 & $\begin{array}{l}\text { Scenic and sightseeing transportation and } \\
\text { support activities for transportation }\end{array}$ & $29,633.85$ & $41,000.83$ & $49,322.23$ \\
\hline 63 & Legal services & $29,144.88$ & $61,165.45$ & $61,071.29$ \\
\hline 64 & Retail Stores - Health and personal care & $29,055.31$ & $35,012.93$ & $35,912.97$ \\
\hline 65 & All other miscellaneous manufacturing & $28,956.48$ & $50,864.96$ & $53,630.23$ \\
\hline
\end{tabular}




\begin{tabular}{|c|c|c|c|c|}
\hline 66 & $\begin{array}{l}\text { Retail Stores - Building material and } \\
\text { garden supply }\end{array}$ & $28,865.74$ & $33,928.26$ & $36,095.91$ \\
\hline 67 & Retail Stores - Motor vehicle and parts & $28,369.81$ & $42,298.69$ & $44,619.18$ \\
\hline 68 & $\begin{array}{l}\text { Community food, housing, and other } \\
\text { relief services, including rehabilitation } \\
\text { services }\end{array}$ & $28,355.61$ & $29,340.52$ & $23,022.79$ \\
\hline 69 & $\begin{array}{l}\text { Greenhouse, nursery, and floriculture } \\
\text { production }\end{array}$ & $27,896.25$ & $34,581.58$ & $34,447.63$ \\
\hline 70 & Nursing and residential care facilities & $27,833.56$ & $34,958.21$ & $32,832.72$ \\
\hline 71 & $\begin{array}{l}\text { Private elementary and secondary } \\
\text { schools }\end{array}$ & $27,327.16$ & $29,654.75$ & $29,549.69$ \\
\hline 72 & $\begin{array}{l}\text { Maintenance and repair construction of } \\
\text { nonresidential structures }\end{array}$ & $27,061.38$ & $40,268.08$ & $39,123.03$ \\
\hline 73 & Printing & $27,060.84$ & $51,326.51$ & $49,379.21$ \\
\hline 74 & $\begin{array}{l}\text { Construction of other new nonresidential } \\
\text { structures }\end{array}$ & $27,018.50$ & $39,774.51$ & $38,518.86$ \\
\hline 75 & Business support services & $26,936.64$ & $32,410.91$ & $29,775.76$ \\
\hline 76 & $\begin{array}{l}\begin{array}{l}\text { Construction of new nonresidential } \\
\text { manufacturing structures }\end{array} \\
\end{array}$ & $26,855.11$ & $39,737.66$ & $38,569.63$ \\
\hline 77 & $\begin{array}{l}\text { Construction of new residential } \\
\text { permanent site single- and multi-family } \\
\text { structures }\end{array}$ & $26,855.03$ & $39,709.80$ & $38,537.87$ \\
\hline 78 & \begin{tabular}{|l|}
$\begin{array}{l}\text { Construction of other new residential } \\
\text { structures }\end{array}$ \\
\end{tabular} & $26,854.99$ & $39,709.76$ & $38,537.83$ \\
\hline 79 & $\begin{array}{l}\text { Construction of new nonresidential } \\
\text { commercial and health care structures }\end{array}$ & $26,829.43$ & $39,749.83$ & $38,552.51$ \\
\hline 80 & $\begin{array}{l}\text { Scientific research and development } \\
\text { services }\end{array}$ & $26,766.95$ & $86,697.64$ & $73,112.02$ \\
\hline 81 & Bowling centers & $26,561.14$ & $16,807.26$ & $16,674.54$ \\
\hline 82 & Vegetable and melon farming & $25,838.75$ & $22,152.58$ & $27,726.00$ \\
\hline 83 & $\begin{array}{l}\text { Retail Stores - Furniture and home } \\
\text { furnishings }\end{array}$ & $24,228.05$ & $31,449.61$ & $33,349.97$ \\
\hline 84 & Retail Stores - General merchandise & $23,941.25$ & $24,682.65$ & $27,087.89$ \\
\hline 85 & $\begin{array}{l}\text { Wood windows and doors and millwork } \\
\text { manufacturing }\end{array}$ & $23,848.06$ & $38,821.01$ & $43,115.87$ \\
\hline 86 & Individual and family services & $23,388.00$ & $22,227.71$ & $21,044.93$ \\
\hline 87 & Veterinary services & $23,013.25$ & $27,598.42$ & $24,276.16$ \\
\hline 88 & Services to buildings and dwellings & $22,899.61$ & $21,486.32$ & $20,888.88$ \\
\hline 89 & $\begin{array}{l}\text { Maintenance and repair construction of } \\
\text { residential structures }\end{array}$ & $22,788.70$ & $33,697.03$ & $32,702.55$ \\
\hline 90 & All other crop farming & $22,360.03$ & $14,417.17$ & $16,284.57$ \\
\hline 91 & $\begin{array}{l}\text { Commercial and industrial machinery } \\
\text { and equipment rental and leasing }\end{array}$ & $22,068.48$ & $63,857.61$ & $56,402.53$ \\
\hline 92 & Employment services & $22,055.64$ & $26,071.19$ & $25,694.07$ \\
\hline 93 & Photographic services & $21,888.75$ & $16,140.12$ & $18,749.23$ \\
\hline 94 & Retail Stores - Food and beverage & $21,547.52$ & $24,429.87$ & $27,300.32$ \\
\hline 95 & Wood container and pallet manufacturing & $21,112.40$ & $33,386.86$ & $35,516.45$ \\
\hline 96 & Retail Stores - Electronics and appliances & $20,975.71$ & $38,981.56$ & $45,053.35$ \\
\hline 97 & \begin{tabular}{|l|}
$\begin{array}{l}\text { Prefabricated wood building } \\
\text { manufacturing }\end{array}$ \\
\end{tabular} & $20,919.05$ & $37,983.89$ & $42,060.35$ \\
\hline 98 & $\begin{array}{l}\text { All other miscellaneous wood product } \\
\text { manufacturing }\end{array}$ & $20,747.36$ & $37,790.39$ & $39,487.40$ \\
\hline
\end{tabular}




\begin{tabular}{|c|c|c|c|c|}
\hline 99 & Other support services & $20,690.77$ & $26,726.34$ & $33,150.81$ \\
\hline$\overline{100}$ & Newspaper publishers & $20,301.21$ & $42,879.82$ & $45,286.77$ \\
\hline 101 & Retail Stores - Gasoline stations & $20,235.59$ & $21,443.97$ & $22,870.59$ \\
\hline 102 & Child day care services & $19,935.45$ & $19,025.30$ & $16,659.24$ \\
\hline 103 & Fruit farming & $19,140.81$ & $17,416.15$ & $23,002.97$ \\
\hline 104 & Investigation and security services & $19,058.61$ & $25,385.09$ & $24,753.05$ \\
\hline 105 & Sawmills and wood preservation & $18,442.05$ & $34,438.92$ & $43,370.33$ \\
\hline 106 & $\begin{array}{l}\text { General and consumer goods rental } \\
\text { except video tapes and discs }\end{array}$ & $17,579.98$ & $35,474.58$ & $33,921.42$ \\
\hline 107 & $\begin{array}{l}\text { Civic, social, professional, and similar } \\
\text { organizations }\end{array}$ & $17,369.83$ & $28,757.07$ & $36,561.31$ \\
\hline 108 & $\begin{array}{l}\text { Amusement parks, arcades, and gambling } \\
\text { industries }\end{array}$ & $17,277.73$ & $25,193.93$ & $29,824.43$ \\
\hline 109 & \begin{tabular}{|l|} 
Accounting, tax preparation, \\
bookkeeping, and payroll services
\end{tabular} & $17,152.20$ & $44,179.82$ & $43,135.40$ \\
\hline 110 & \begin{tabular}{|l|} 
Securities, commodity contracts, \\
investments, and related activities
\end{tabular} & $16,402.45$ & $43,955.02$ & $63,843.42$ \\
\hline 111 & $\begin{array}{l}\text { Hotels and motels, including casino } \\
\text { hotels }\end{array}$ & $16,349.69$ & $27,837.38$ & $33,344.11$ \\
\hline 112 & $\begin{array}{l}\text { Transit and ground passenger } \\
\text { transportation }\end{array}$ & $15,786.77$ & $20,018.69$ & $22,555.97$ \\
\hline 113 & $\begin{array}{l}\text { Commercial and industrial machinery } \\
\text { and equipment repair and maintenance }\end{array}$ & $15,525.88$ & $41,137.34$ & $40,148.28$ \\
\hline 114 & Death care services & $15,503.22$ & $31,551.43$ & $29,009.08$ \\
\hline 115 & Other personal services & $15,169.38$ & $21,735.24$ & $20,698.68$ \\
\hline 116 & Other private educational services & $15,163.22$ & $27,469.79$ & $26,826.42$ \\
\hline 117 & Food services and drinking places & $14,914.02$ & $18,514.96$ & $19,930.33$ \\
\hline 118 & Video tape and disc rental & $14,544.54$ & $14,761.32$ & $13,867.63$ \\
\hline 119 & $\begin{array}{l}\text { Retail Nonstores - Direct and electronic } \\
\text { sales }\end{array}$ & $14,444.06$ & $18,892.92$ & $13,965.13$ \\
\hline 120 & Advertising and related services & $14,350.21$ & $39,239.83$ & $45,591.98$ \\
\hline 121 & $\begin{array}{l}\text { Retail Stores - Clothing and clothing } \\
\text { accessories }\end{array}$ & $14,120.14$ & $19,135.37$ & $20,907.18$ \\
\hline 122 & Transport by truck & $13,578.96$ & $39,933.07$ & $34,513.03$ \\
\hline 123 & Religious organizations & $12,998.57$ & $26,037.62$ & $27,682.73$ \\
\hline 124 & $\begin{array}{l}\text { Personal and household goods repair and } \\
\text { maintenance }\end{array}$ & $12,503.49$ & $22,632.89$ & $22,234.17$ \\
\hline 125 & $\begin{array}{l}\text { Museums, historical sites, zoos, and } \\
\text { parks }\end{array}$ & $11,767.45$ & $33,699.47$ & $35,872.25$ \\
\hline 126 & Spectator sports companies & $11,574.07$ & $39,933.57$ & $29,316.45$ \\
\hline 127 & Other information services & $11,447.66$ & $36,131.67$ & $88,830.97$ \\
\hline 128 & $\begin{array}{l}\text { Automotive repair and maintenance, } \\
\text { except car washes }\end{array}$ & $10,908.02$ & $24,170.20$ & $24,281.65$ \\
\hline 129 & Retail Stores - Miscellaneous & $10,788.32$ & $12,670.07$ & $14,871.25$ \\
\hline 130 & Dry-cleaning and laundry services & $10,378.11$ & $25,499.77$ & $21,214.03$ \\
\hline 131 & Personal care services & $9,155.34$ & $17,380.12$ & $16,792.21$ \\
\hline 132 & $\begin{array}{l}\text { Retail Stores - Sporting goods, hobby, } \\
\text { book and music }\end{array}$ & $8,899.81$ & $16,119.74$ & $18,889.36$ \\
\hline 133 & Fitness and recreational sports centers & $8,380.12$ & $14,304.67$ & $17,542.78$ \\
\hline 134 & Automotive equipment rental and leasing & $7,372.09$ & $41,094.04$ & $34,704.42$ \\
\hline 135 & Cattle ranching and farming & $7,174.13$ & $6,710.41$ & $7,574.13$ \\
\hline 136 & Real estate establishments & $6,051.55$ & $8,554.64$ & $10,324.91$ \\
\hline
\end{tabular}




\begin{tabular}{|c|c|c|c|c|}
\hline 137 & Dairy cattle and milk production & $5,926.44$ & $6,070.02$ & $7,574.10$ \\
\hline 138 & Private household operations & $5,509.11$ & $6,356.61$ & $7,926.49$ \\
\hline 139 & Commercial logging & $4,937.78$ & $7,749.53$ & $21,799.09$ \\
\hline 140 & $\begin{array}{l}\text { Animal production, except cattle and } \\
\text { poultry and eggs }\end{array}$ & $4,670.85$ & $4,794.17$ & $5,857.18$ \\
\hline 141 & Motion picture and video industries & $4,484.38$ & $32,952.76$ & $59,789.06$ \\
\hline 142 & $\begin{array}{l}\begin{array}{l}\text { Support activities for agriculture and } \\
\text { forestry }\end{array} \\
\end{array}$ & $3,589.97$ & $16,753.02$ & $21,157.95$ \\
\hline 143 & $\begin{array}{l}\text { Promoters of performing arts and sports } \\
\text { and agents for public figures }\end{array}$ & $2,431.93$ & $7,777.20$ & $12,362.07$ \\
\hline 144 & Grain farming & $1,274.87$ & $1,370.38$ & $2,088.11$ \\
\hline 145 & Oilseed farming & 456.87 & 526.89 & 741.01 \\
\hline 146 & Commercial hunting and trapping & 0.00 & 837.96 & $3,437.66$ \\
\hline 147 & Couriers and messengers & 0.00 & $36,535.45$ & $36,692.48$ \\
\hline 148 & Extraction of oil and natural gas & 0.00 & $21,508.55$ & $53,166.42$ \\
\hline 149 & Transport by air & 0.00 & $66,511.36$ & $75,939.81$ \\
\hline
\end{tabular}

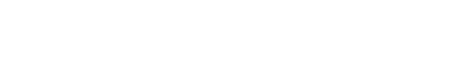
ou=Acquisitions Department, 